GABRIEL LORETTO LOCHAGIN

\title{
A flexibilidade da execução orçamentária
}

Dissertação de Mestrado apresentada à Banca Examinadora da Universidade de São Paulo como requisito parcial para a obtenção do título de Mestre, na área de concentração Direito Econômico-Financeiro, sob orientação do Prof. Associado José Maurício Conti 
Nome: LOCHAGIN, Gabriel Loretto

Título: A flexibilidade da execução orçamentária

Dissertação de Mestrado apresentada à Banca Examinadora da Universidade de São Paulo como requisito parcial para a obtenção do título de Mestre, na área de concentração Direito Econômico-Financeiro, sob orientação do Prof. Associado José Maurício Conti

Aprovado em:

BANCA EXAMINADORA

Prof. Dr.: Instituição:

Julgamento: Assinatura:

Prof. Dr.: Instituição:

Julgamento: Assinatura:

Prof. Dr.: Instituição:

Julgamento: Assinatura: 
Para minha família, Nikolas, Roseli e Cecília. 


\section{AGRADECIMENTOS}

Foram muitos os apoios recebidos para a realização do trabalho, dependente de tantas contribuições.

Agradeço ao Prof. Dr. José Maurício Conti, fonte de infindável estímulo para o estudo do Direito Financeiro. A conversa franca, a capacidade de propor soluções e o aguçado senso crítico foram algumas das qualidades que tornaram extremamente valiosa a experiência da pós-graduação. O interesse pelo desenvolvimento do trabalho e, sobretudo, a amizade demonstrada completaram as virtudes de uma excelente orientação.

Igualmente, agradeço ao Prof. Dr. Fernando Facury Scaff, cuja perspicácia, tanto nas disciplinas cursadas como no exame de qualificação, sempre é capaz de apontar novos caminhos e possibilidades de investigação. A propósito do exame de qualificação, agradeço também à Profa. Dra. Ana Carla Bliacheriene, cujos comentários permitiram uma mais profunda reflexão sobre os propósitos do trabalho.

Meus agradecimentos, ainda, a meus tios Diógenes Pereira Gonzaga, Elisabeth Loshchagin Pizzolitto e Galina Loschtschagina Gonzaga, com cujo apoio contei desde os primeiros momentos da graduação e pelo qual serei sempre grato.

Finalmente, agradeço à FAPESP, que amparou financeiramente a realização do trabalho durante os anos de 2010 e 2011, e ao DAAD (Deutscher Akademischer Austauschdienst), pela bolsa concedida para temporada de curta duração na Universidade de Colônia. 


\section{RESUMO}

LOCHAGIN, G. L. A Flexibilidade da Execução Orçamentária. 2012. 169 p. Dissertação (Mestrado) - Faculdade de Direito, Universidade de São Paulo, São Paulo, 2012.

A flexibilidade da execução do orçamento exige que diversos instrumentos sejam utilizados, os quais não são homogêneos no que se refere à participação do Poder Legislativo. Em algumas situações, este necessita se manifestar prévia e especificamente, aprovando créditos suplementares que estão fora das margens de remanejamento, créditos especiais e transferências. Em outros casos, a decisão do parlamento é enfraquecida, como nos créditos suplementares abertos nos limites das margens de remanejamento ou nos créditos extraordinários. Nos primeiros, a autorização parlamentar é concedida anteriormente à necessidade de suplementação, de forma genérica. Nos segundos, a abertura dá-se por medida provisória, nem sempre se cumprindo o requisito da imprevisibilidade. É, porém, nos casos em que o Poder Executivo promove o contingenciamento de recursos que o controle exercido pelo Legislativo se mostra mais tênue. Justificam-no algumas concepções predominantes sobre o orçamento. De um lado, a divisão do ciclo orçamentário em fases distribuídas com exclusividade entre Executivo e Legislativo, em que o governo elabora e executa o orçamento, ao passo que o parlamento o aprova e controla sua execução, pode dar a entender que as decisões que necessitam ser tomadas na fase de execução orçamentária competem exclusivamente ao Poder Executivo. De outro lado, é dominante a ideia de que a natureza jurídica do orçamento é a de uma lei meramente formal da qual não se podem extrair obrigações positivas ao governo para determinar o gasto até o teto das dotações. Estas noções têm suas origens em momentos históricos e situações constitucionais distintos e não mais prevalecem diante das funções orçamentárias do parlamento, a quem compete aprovar a lei e decidir a propósito de políticas, que subordinam a atividade administrativa de execução. Diante disso, o orçamento impositivo se mostra uma forma possível de melhorar o cumprimento da vontade parlamentar e aprimorar o planejamento, embora encontre dificuldades de implementação.

Palavras-chave: execução orçamentária; flexibilidade; créditos adicionais; contingenciamento; orçamento impositivo 


\section{ZUSAMMENFASSUNG}

LOCHAGIN, G. L. Die Flexibilität des Haushaltsvollzuges. 2012. 169 p. Dissertação (Mestrado) - Faculdade de Direito, Universidade de São Paulo, São Paulo, 2012.

Die Flexibilität des Haushaltsvollzuges setzt die Anwendung vielfältiger Instrumente voraus, die nicht homogen hinsichtlich der Mitwirkung der gesetzgebenden Gewalt sind. In gewissen Fällen muss die Legislative sich vorher und spezifisch manifestieren, indem sie über- oder außerplanmäßige Ausgaben bewilligt. In anderen Fällen ist die parlamentarische Entscheidung weicher, einige außerplanmäßige Krediten können nämlich entweder vorher pauschal oder durch ein Dekret in außergewöhlichen Situationen ermächtigt werden. Im letzten Fall ist die Voraussetzung der Unvorhersehbarkeit nicht immer beobachtet. Die legislative Kontrolle zeigt sich aber enorm abgeschwächt, wenn die Regierung entscheidet, Ausgaben zu sperren. Man findet in der beherrschenden Meinung des Haushaltsrechts eine Begründung dafür. Der Budgetkreislauf ist in verschiedenen Phasen geteilt, in denen die Regierung das Budget vorbereit und ausführt, während das Parlament für die Feststellung und Kontrolle des Vollzuges zuständig ist. Diese Aussage kann hindeuten, dass der Etat zum Eigenbereich der Exekutive gehört. Auf der anderen Seite geht die bislang vorherrschende Rechtsansicht davon aus, dass das Budget mangels eines materiellen Rechtssatzcharakters eine bindende Verpflichtung der Regierung zu seinem Vollzug nicht enthalten könne. Diese Rechtsansichten werden auf unterschiedlichen historischen Zeitpunkten und verfassungsrechtlichen Kontexten zurückbezogen. Die veränderte Verfassungslage unter der Bundesverfassung hat eine umfassende Prärogative des Parlaments eingeführt, die die parlamentarische Entscheidung des Haushaltsgesetz zuläßt. Angesichts der politischen Bedeutung des staatlichen Haushalts muss die Verwaltungstätigkeit, die im Haushaltsvollzug stattfindet, der Politik und dem Gesetz unterordnen. In dieser Hinsicht zeigt sich ein bindendes Haushaltsgesetz als eine Möglichkeit, die Planung und die parlamentarische Bewilligung zu stärken, wenn es auch Ausführungsschwierigkeiten gibt.

Schlüsselwörter: Haushaltsvollzug; Flexibilität; über- und außerplanmäßige Krediten; Sperrvermerke; bindendes Haushaltsgesetz. 


\section{LISTA DE FIGURAS}

Figura 01 - Créditos extraordinários previstos e executados de 1999 a 2009 131 


\section{SUMÁRIO}

1. INTRODUÇÃO 10

2. A DISTRIBUIÇÃO CONSTITUCIONAL DO PODER FINANCEIRO 15

2.1. LIMITAÇÕES CONSTITUCIONAIS À FUNÇÃO FINANCEIRA 16

2.1.1. O exercício do Poder do Estado por meios financeiros 16

2.1.2. A organização das finanças públicas 18

2.1.3. A separação constitucional dos poderes financeiros 21

2.1.4. Distribuição de competências no ciclo orçamentário: duas tradições 23

2.1.4.1. Uma tradição: o orçamento do executivo e a purificação da política 24

2.1.4.2. Outra tradição: o orçamento como lei meramente formal. 32

2.1.4.2.1. O anacronismo da doutrina dominante. 33

2.1.4.2.2. Condições históricas do surgimento do direito orçamentário 39

2.1.5. As transformações das funções do orçamento 45

2.1.5.1. A superação do paradigma do controle 45

2.1.5.2. Orçamento e planejamento. 50

2.1.5.3. Os limites da decisão de planejar 54

2.2. A AUTORIDADE DO PODER LEGISLATIVO SOBRE O ORÇAMENTO 59

2.2.1. Administração, política e lei 59

2.2.2. Competências orçamentárias do Poder Legislativo 64 


\subsection{LIMITES JURÍDICOS À FLEXIBILIDADE DA EXECUÇÃO}

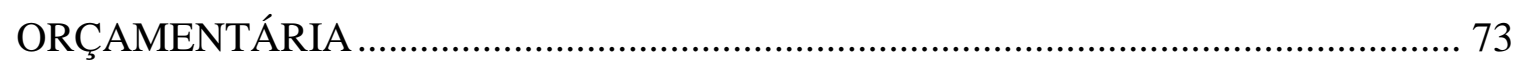

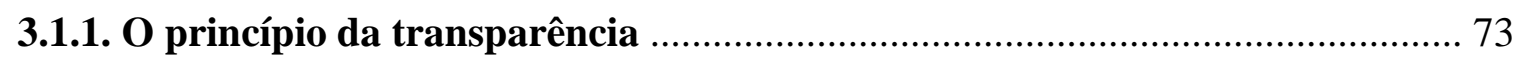

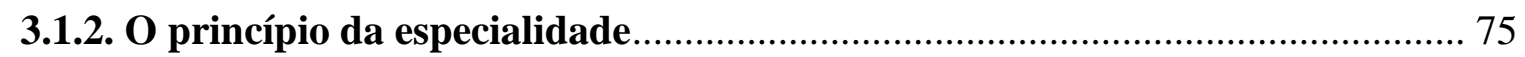

3.1.2.1. A especialidade temporal: o exercício financeiro e atenuações ao princípio da

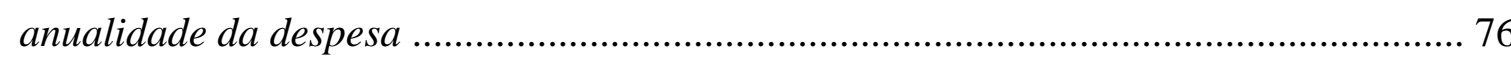

3.1.2.2. A especialidade material: aspectos quantitativo e qualitativo............................ 77

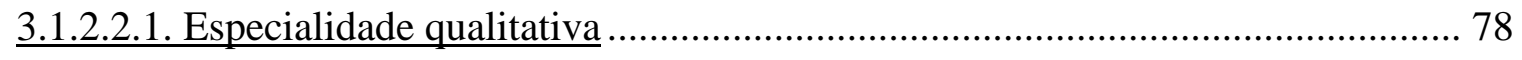

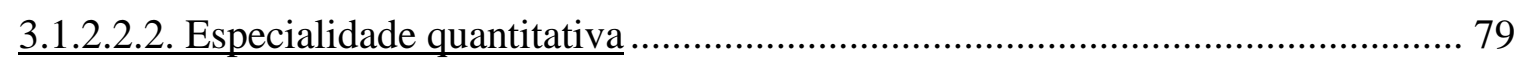

3.2. A EXECUÇÃO DO ORÇAMENTO BRASILEIRO: DO REGISTRO DOS

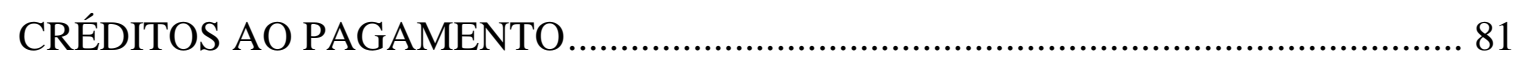

3.2.1. O orçamento analítico como expressão da especialidade orçamentária ......... 81

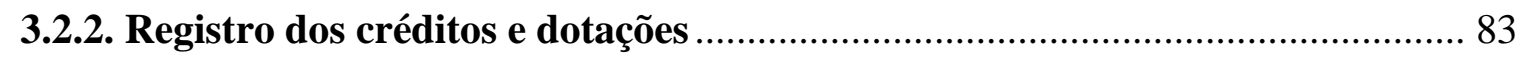

3.2.3. Programação financeira e cronograma do desembolso ................................ 87

3.2.4. Estágios da despesa: empenho, liquidação e pagamento ................................ 91

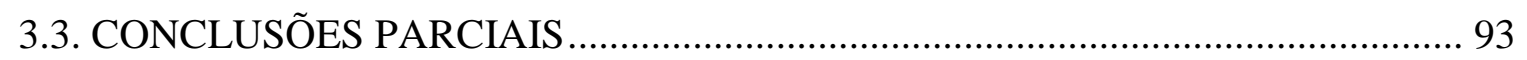

\section{A HETEROGENEIDADE DOS INSTRUMENTOS DE FLEXIBILIDADE}

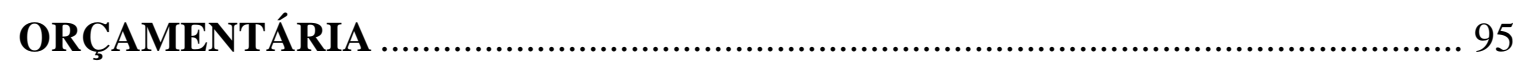

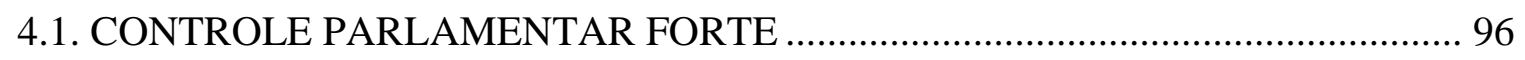

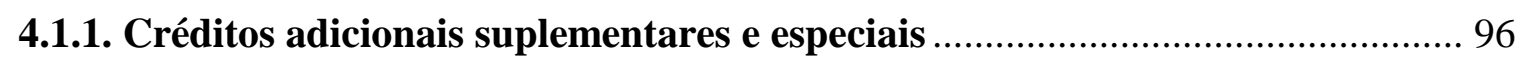

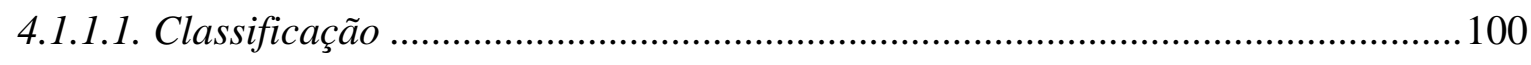

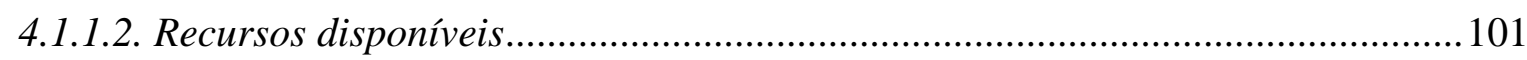




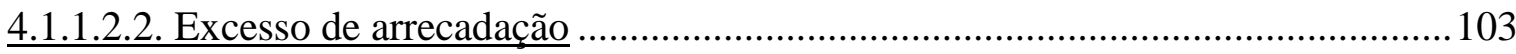

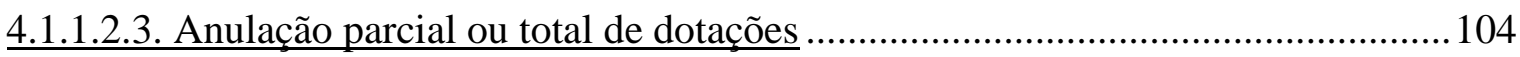

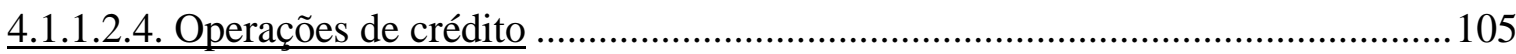

4.1.1.3. Compatibilidade dos créditos adicionais com as leis orçamentárias ..................106

4.1.1.4. Fases administrativa e legislativa dos créditos adicionais ................................109

4.1.1.4.1. Fase administrativa: alterações quantitativas e qualitativas ............................. 111

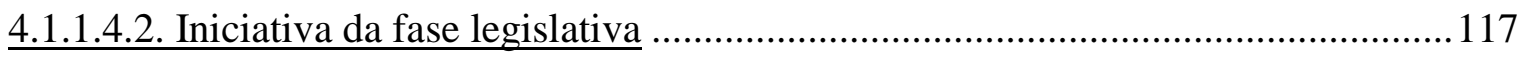

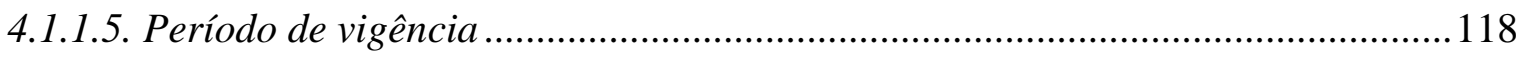

4.1.2. Transferências, remanejamentos e transposições............................................ 119

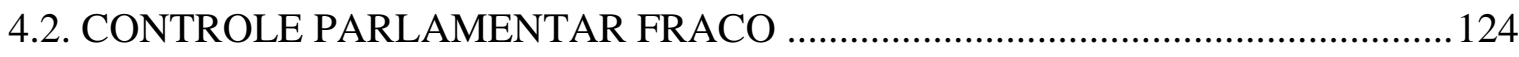

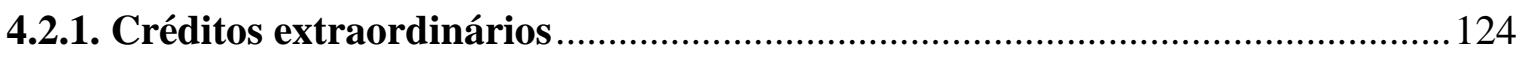

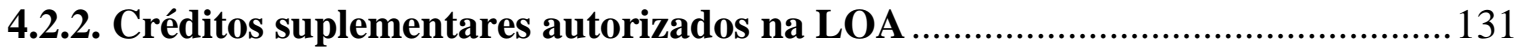

4.3. CONTROLE PARLAMENTAR FRAQUÍSSIMO: LIMITAÇÃO DE EMPENHO

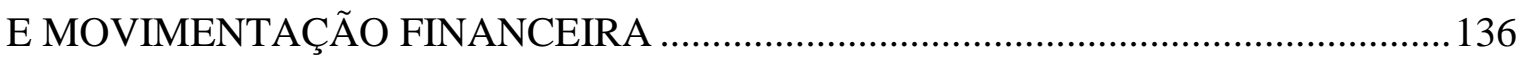

4.3.1. Novamente dois casos: Alemanha e Estados Unidos da América ....................139

4.3.2. O orçamento impositivo e a revisão das relações de poder ……...................... 145

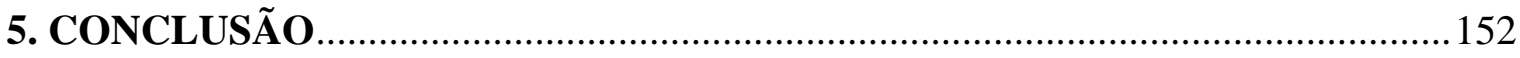

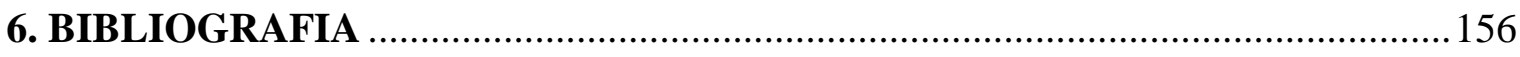




\section{INTRODUÇÃO}

O orçamento deve ser executado da maneira como o Parlamento o votou, de modo que os recursos públicos sejam destinados às necessidades ali escolhidas e não a outras. Orçamentos incompletos ou inexatos são prejudiciais. Denotam mau trabalho do Poder Executivo, senão deliberada tentativa de escapar às suas responsabilidades. Indicam também a falta de controle do Poder Legislativo. O governo abusa dos créditos suplementares e extraordinários, não raro tomando um pelo outro. É preciso que os representantes do povo retomem suas prerrogativas e que o governo elabore propostas orçamentárias sinceras, porque, como preconiza o velho adágio, "boas finanças, boa política". E as alterações necessárias, destoantes das dotações votadas, que sejam feitas conforme a lei.

Não tivessem sido expressas em 1880 por um senador do Império ${ }^{1}$, estas ideias poderiam ser encontradas atualmente em qualquer editorial ou discurso de um parlamentar insatisfeito. Se fosse perguntado sobre a existência de uma linha de continuidade na história orçamentária do Brasil, a secular diferença entre o orçamento votado e o orçamento executado seria uma boa resposta.

Isto se deve a uma série de instrumentos que autorizam a flexibilidade da execução orçamentária. Por cumprir diversas funções, o orçamento público, não poucas vezes, depara-se com intrincada sorte de problemas, conflitos e urgências presentes, por assim dizer, no ambiente em que ele se insere. Não são apenas embates decorrentes do bem conhecido fato das necessidades serem ilimitadas e os recursos, escassos - o que leva o administrador a realizar, inevitavelmente, escolhas trágicas na elaboração da proposta. Trata-se, antes, de uma questão estrutural de todo orçamento público, amplificadora das dificuldades que já seriam grandes se apenas fosse considerado o modo como se deve elaborar o seu conteúdo. Estas dificuldades aparecem no momento de executá-lo, em que o cumprimento da proposta inicial e necessidades imprevistas ou impostergáveis provocam sua contínua revisão.

\footnotetext{
${ }^{1}$ CARREIRA, Liberato de Castro. História Financeira e Orçamentária do Império do Brazil desde a sua Fundação. Rio de Janeiro: Imprensa Nacional, 1880, p. 5 e ss; p. 300-1.
} 
Esta maleabilidade do orçamento faz com que nada pareça mais distante do que o sentido original da palavra budget - a bolsa que contém todas as contas do Estado -, embora as raízes etimológicas do termo ainda se deixem entrever quando se ouve falar dos "pacotes" econômicos dos quais o governo brasileiro tantas vezes teve que lançar mão. O orçamento como único pacote levado pelo Chancellor of the Exchequer ao Parlamento inglês soa uma figura antiga. Verdadeiramente, a tradicional cerimônia em que o ministro britânico das Finanças assoma à porta do número 11 de Downing Street carregando a caixa de Gladstone, com o discurso que levará ao Parlamento no Dia do Orçamento, poderia bem ser finalizada com a seguinte ressalva: não lacrem a bolsa. Depois de discutida e aprovada, a lei orçamentária ainda passará por outras tantas modificações.

No caso brasileiro, menos cerimonioso, a apresentação do orçamento se dá por leis distintas, em períodos distintos, com prazos de vigência diferentes, para médio e curto prazo, devendo, entretanto, apresentar coerência entre si. Os inúmeros projetos de suplementação e de criação de novos programas, ou, ainda, o atraso na liberação dos recursos, continuam a ser uma constante. As despesas, depois de aprovadas, podem ser - e de fato o são - contingenciadas, por decreto, pelos mais diferentes motivos, seja porque a arrecadação não atendeu às expectativas, seja porque sempre se pode barganhar ao desbloqueá-las. No final das contas, o orçamento nacional é um conjunto de ações em contínua transformação.

Propondo-se esta dissertação a tratar do tema da flexibilidade da execução orçamentária, haveria diversas formas de proceder. Uma delas seria levar em consideração a execução como uma fase do ciclo orçamentário que deve cumprir algumas finalidades jurídica e politicamente desejáveis, de modo que servisse exclusivamente para garantir o cumprimento dos programas aprovados no orçamento. Poder-se-ia optar, desta forma, pela análise e construção de um assim generosamente chamado tipo-ideal de execução. Outra perspectiva poderia ser a de levar em conta, empiricamente, o substrato jurídico-positivo ou mesmo político no seio do qual operam as normas e os interesses de modificação dos créditos no caso brasileiro. Ao menos dois eixos de análise, respectivamente normativo e positivo, seriam, então, possíveis.

Tais modelos apresentariam duas incompletudes fundamentais: no primeiro caso, seriam descritas, com caráter de recomendação, práticas que dificilmente são, de 
forma integral, observadas por algum Estado. No segundo caso, a exclusiva análise do que de fato está previsto nas normas e ocorre na realidade poderia obscurecer a preocupação com a necessidade de se dotar o ciclo orçamentário de maior sistematicidade entre suas fases para que o orçamento possa cumprir seus objetivos.

Este trabalho se lançará por outro caminho, procurando o contraste entre uma execução orçamentária destinada a assegurar o cumprimento da proposta inicial com um grau adequado de eficiência na gestão, e a forma como ela foi, efetivamente, organizada no Brasil. Constrói-se, então, a seguinte hipótese: a de que há um desencontro entre as práticas mais recomendáveis de execução orçamentária e a organização do orçamento nacional. Não que estejam completamente dissociadas: seria flagrantemente incorreto dizer que os princípios tradicionais que regem a matéria e que recomendam a imposição de limites à possibilidade de o Executivo alterar livremente o orçamento não se encontram acolhidos pela norma posta. Ocorre que o direito orçamentário brasileiro apresenta-se, em alguns aspectos, como uma estrutura assistemática em que, ao mesmo tempo em que procura restringir a discricionariedade governamental de flexibilização da execução do orçamento, consagra permissões para que ela ocorra. Tais permissões parecem surgir principalmente em razão de normas que, ao distribuírem competências orçamentárias na fase de execução, facilitam que o Executivo se valha de atos próprios para alterar o orçamento votado, muitas vezes restringindo-se o controle exercido pelo Poder Legislativo ao controle político.

Esta incompatibilidade entre uma estrutura orçamentária que garanta o cumprimento da vontade parlamentar e a amplitude dos instrumentos de flexibilidade à disposição do Executivo parece surgir não apenas de incongruências da norma posta, mas do anacronismo de interpretações insistentemente repetidas. É possível que algumas prerrogativas do Poder Executivo na fase de execução decorram de arraigadas opiniões a respeito do orçamento público, sem que encontrem, hoje, suficiente amparo constitucional. A ideia de que a execução orçamentária é matéria de competência privativa do Poder Executivo, excluindo-se a possibilidade constitucional do exercício de competências parlamentares nesta fase, parece se situar nesta categoria de anacronismos hermenêuticos.

A metodologia adotada pelo trabalho é bastante simples: numa primeira parte, serão expostos os fundamentos constitucionais da distribuição de competências entre os 
Poderes Executivo e Legislativo no ciclo orçamentário, de modo que se possa definir a qual desses órgãos, e em que extensão, se atribui o poder de executar o orçamento. Em seguida, a fase de execução será apreciada em seu caráter mais abstrato, considerando suas principais finalidades, que acabam por lhe conferir racionalidade própria, distinta daquela apresentada na fase de elaboração e aprovação do orçamento. Numa terceira parte, será analisado o caso brasileiro, procurando levar em conta como as normas de atribuição de competências na fase de execução procuram, em partes, assegurar o cumprimento da lei orçamentária (atendendo a recomendações de índole técnica e política), mas, concomitantemente, apresentam particularidades que podem estimular o Poder Executivo a se sobrepor à vontade parlamentar originalmente expressa no orçamento aprovado, não raro com o consentimento do próprio Parlamento. Duas ressalvas quanto a esta segunda parte: para tratar do caso brasileiro não se prescindirá de recorrer a exemplos internacionais, de maneira a perceber em que aspectos estes se assemelham ou se dissociam daquele; e o enfoque da análise será dado à relação que Executivo e Legislativo estabelecem entre si nesta etapa do ciclo orçamentário - não porque sejam os únicos agentes do orçamento público, mas porque são os agentes que concentram a maior quantidade de competências e em função dos quais se organiza o ciclo orçamentário, tornando-se, assim, seus atores principais.

O segundo capítulo dedica-se ao estudo constitucional do ciclo orçamentário, com a finalidade principal de investigar a "metafísica influente" do direito orçamentário que, por diferentes fundamentos, conclui pela competência privativa do Poder Executivo na fase de execução. Com isto, espera-se saber mais sobre a possibilidade de interferências do Poder Legislativo nesta fase.

Àquela segunda parte corresponde o terceiro capítulo, denominado "Finalidades da execução orçamentária". Aí se alinhará a ideia de que os instrumentos de flexibilidade orçamentária devem ser adotados apenas e tão somente à medida que permitam ao Poder Executivo (que toma a maioria das decisões de executar o orçamento) se aproximar da vontade manifesta no documento aprovado pelo Poder Legislativo. Por esta razão, o orçamento é visto, neste sistema ideal-típico de execução orçamentária, como uma solução aos conflitos que eventualmente surjam entre os Poderes: na dúvida entre a adoção de medidas administrativas que se afastem e outras que se aproximem dos programas votados, deve-se optar por estas segundas. E caso haja 
suficiente justificativa para que outra decisão seja tomada, que o Poder Legislativo assim autorize. Os atos de execução devem se propor, pois, a cumprir o que foi acertado entre governo e parlamento no momento de aprovação do orçamento, preservando a autoridade do Poder Legislativo, e não do Poder Executivo.

A terceira e última parte se encontra no capítulo nomeado "A heterogeneidade dos instrumentos de flexibilidade orçamentária". Aí se procurará mostrar que diversas normas recomendam o cumprimento da proposta inicial. Outras, porém, se não conferem explicitamente ao Poder Executivo a competência de alterar livremente o orçamento, acabam por lhe facultar a adoção de instrumentos em que ou a anuência parlamentar é vaga e imprecisa, ou efetivamente não existe. Procurar-se-á mostrar a execução orçamentária brasileira, desta forma, como uma estrutura assistemática em que se identificam duas racionalidades conflitantes. De um lado, aquela associada ao princípio da legalidade - se o orçamento é aprovado por lei, também suas alterações devem sê-lo. De outra parte, aquela ligada a uma flexibilidade autônoma, sem relação com os créditos especificados no orçamento: a própria ordem jurídica parece permitir que essa autorização legislativa ou seja conferida previamente à decisão do Executivo e em caráter demasiadamente genérico (é o caso das margens de remanejamento), ou que a decisão de não gastar os montantes aprovados seja tomada exclusivamente pelo governo. Neste sentido, por diversas razões os programas do orçamento inicial podem ser vistos como um obstáculo aos interesses do governo, que dispõe de instrumentos para contorná-lo. 


\section{A DISTRIBUIÇÃO CONSTITUCIONAL DO PODER FINANCEIRO}

Les finances sont les nerfs de la République.

Jean Bodin, 1576

Para expor as finalidades ideais da execução orçamentária, deve-se estabelecer um parâmetro do que seja este sistema ideal. Isto é, com base em quais critérios pode-se considerar um sistema de execução orçamentária como o melhor possível. Este capítulo responde a esta pergunta em torno de dois eixos: a) ideal em relação a uma ordem constitucional financeira em que se prevejam separação de poderes e limitações à função financeira do Estado, garantindo-se na execução a autoridade do Parlamento; e b) ideal em relação a paradigmas de boa gestão, que preconizam a adequação do orçamento a um planejamento prévio e sua adaptabilidade à conjuntura. Estes eixos não se excluem mutuamente, mas apresentam enfoques distintos.

Quanto ao primeiro aspecto, não faria sentido discutir uma fase de execução orçamentária fora de um Estado Democrático de Direito. Este remete, inexoravelmente, à presença de uma Constituição que assegure a separação de Poderes e limitações ao exercício do poder. A execução, como fase de um ciclo, existe em função da distribuição de competências entre os diversos Poderes do Estado, o que careceria de sentido caso todas as competências financeiras estivessem nas mãos de um único agente. Apenas se pode distinguir a fase de execução de outras fases do ciclo orçamentário em situações nas quais exista um sistema de freios e contrapesos manifesto em etapas de elaboração, aprovação, execução e controle do orçamento público.

De outra parte, a construção desta noção de execução orçamentária deve levar em conta, também, a necessidade de se garantir certa flexibilidade à gestão do orçamento, para que este se adapte às circunstâncias. Flexibilidade e respeito à decisão parlamentar são duas noções fundamentais, portanto. Embora em primeira análise possam parecer conflitantes, não é possível conceber esta flexibilidade como algo fora do alcance da legalidade, pois o objetivo será cumprir o orçamento aprovado. A 
articulação entre estas duas perspectivas será esboçada neste capítulo e terá maior detalhamento no próximo.

\subsection{Limitações constitucionais à função financeira}

Neste item se estabelecerão os principais fundamentos da limitação constitucional do exercício do poder financeiro do Estado, mostrando: que a atuação estatal é, contemporaneamente, indissociável da possibilidade de uso de dinheiro; e que isto implica a sujeição desta função financeira a limitações constitucionais.

\subsubsection{O exercício do Poder do Estado por meios financeiros}

A imagem das finanças como "nervos do Estado", nos termos de Jean Bodin², é sugestiva ao expor os caminhos pelos quais os recursos e estímulos indispensáveis à sobrevivência do conjunto chegam a todas as partes do corpo, mesmo as mais distantes ${ }^{3}$. Mais do que sugestiva, porém, a imagem é acurada: o Estado moderno passou a necessitar de uma diversificada fonte de recursos para atender a suas necessidades. Estas exigências, que o Estado é chamado a satisfazer por seu próprio ordenamento jurídico, não poderiam ser atendidas sem uma quantidade adequada de meios econômicos - observação inicial de Giannini ao tratar do Direito Financeiro. ${ }^{4}$

Trata-se, portanto, de um Estado Financeiro, caracterizado por exercer atividades relacionadas com as finanças públicas ${ }^{5}$. A disponibilidade de recursos

\footnotetext{
${ }^{2}$ A referência, provavelmente, é feita a Ulpiano, Dig. 1. 20: "[tributi] in quibus esse rei publicae nervos". ${ }^{3}$ É de Klaus Vogel a observação de que na Antiguidade e na Idade Média ainda não se distinguiam, possivelmente, os nervos dos vasos sanguíneos (VOGEL, Klaus. Der Finanz- und Steuerstaat. In: ISENSEE, J.; KIRCHHOF, P. (ed.). Handbuch des Staatsrechts. $3^{\mathrm{a}}$ ed. Heidelberg: C. F. Müller Verlag, 2004. v. 2, p. 852).

${ }^{4}$ GIANNINI, A. D. Elementi di Diritto Finanziario. Milano: Giuffrè, 1945, p. 3.

${ }^{5}$ TORRES, Ricardo Lobo. A Ideia de Liberdade no Estado Patrimonial e no Estado Fiscal. Rio de Janeiro: Renovar, 1991, p. 1. Nesta obra, o autor se refere ao problema da liberdade face à tributação como o problema fundamental do Estado Financeiro. Embora este seja, talvez, o aspecto mais importante da questão, parece que a atividade financeira, convertida em atividade jurídica, não tem como único problema a questão tributária, sendo múltipla e de índole variada. Consciente, portanto, de que o tema do Estado Financeiro no mais das vezes é tratado como circunscrito ao aspecto tributário, os problemas de limitação de poder financeiro surgem também na relação entre os próprios órgãos e Poderes do Estado, em razão de sua diversidade (cf. VILLEGAS, Hector. Curso de Finanzas, Derecho Financiero y
} 
financeiros se tornou um elemento da racionalidade de um Estado que se dirige a certos fins. Neste sentido, o dinheiro não é apenas um meio de troca, mas também, e principalmente, "o meio de cálculo econômico mais perfeito, isto é, o meio formalmente mais racional de orientação da ação econômica. ${ }^{\prime 6} \mathrm{O}$ orçamento moderno é, certamente, forma típica de manifestação da economia monetária, embora, como acentua Neumark, o dinheiro como "meio formalmente mais racional" apenas seja uma ideia válida na prática se cada unidade de moeda permanece com valor relativamente constante em um espaço de tempo mais longo. ${ }^{7}$ De qualquer forma, este meio de cálculo foi incorporado à atuação estatal, o que produz efeitos sobre a organização e o modo de trabalho da Administração, conferindo possibilidades de orientação e formas de ação que, em sua ausência, não seriam possíveis ${ }^{8}$, dificilmente se conseguindo ir além de serviços mais simples cuja prestação pode ser exigida diretamente ${ }^{9}$.

Além disso, o dinheiro confere a possibilidade de influenciar comportamentos, servindo de instrumento do Poder do Estado, ampliando ou restringindo liberdades, tanto quanto o fazem os comandos jurídicos ${ }^{10}$. Talcott Parsons chegou a propor, para a sua teoria sociológica dos sistemas, usar uma paradigmática noção de dinheiro, como categoria simbólica, para representar, analogicamente, a noção de poder ${ }^{11}$. Uma análise jurídico-constitucional, porém, precisa tomar o ponto de partida inverso: isto é, não usar o dinheiro como modelo para explicar e exemplificar o exercício do Poder, mas tomar a própria delimitação constitucional do Poder como forma de exercício de todas as suas demais atividades, incluindo a financeira. Para que abastecer o Estado de meios não se torne um fim exclusivo do exercício da função financeira, o estabelecimento de normas constitucionais é necessário, primeiro, para criar e manter condições sob as quais a

Tributario. $9^{\mathrm{a}}$ ed. Buenos Aires: Astrea, 2007, p. 80; FALCÓN Y TELLA, R. Introducción al Derecho Financiero y Tributario de las Comunidades Europeas. Madrid: Civitas, 1988, p. 107).

${ }^{6}$ WEBER, Max. Economia e Sociedade. Trad. de Régis Barbosa e Karen Elsabe Barbosa. 4a ed. São Paulo: UnB, 2004. v. 1, p.53.

${ }^{7}$ NEUMARK, Fritz. Der Reichshaushaltplan: ein Beitrag zur Lehre vom Öffentlichen Haushalt. Jena: Gustav Fischer, 1929, p. 13. Por esta razão foi de pouco significado prático o orçamento no Brasil durante o período de alta inflação.

${ }^{8}$ VOGEL, Klaus. Der Finanz- und Steuerstaat. In: ISENSEE, J.; KIRCHHOF, P. (ed.). Handbuch des Staatsrechts. $3^{\mathrm{a}}$ ed. Heidelberg: C. F. Müller Verlag, 2004, p. 853, v. 2

${ }^{9}$ Esta forma de atingir finalidades não foi totalmente extinta, mas assume, hoje, caráter apenas residual, por exemplo por meio da convocação de cidadãos para atuação como mesários nas eleições ou para composição de júri.

${ }^{10}$ VOGEL, Klaus. Der Finanz- und Steuerstaat. In: ISENSEE, J.; KIRCHHOF, P. (ed.). Handbuch des Staatsrechts. $3^{\mathrm{a}}$ ed. Heidelberg: C. F. Müller Verlag, 2004, p. 854, v. 2

${ }^{11}$ PARSONS, Talcott. On the Concept of Influence. The Public Opinion Quarterly, Chicago, v. 27, n. 1, 1963, p. 37-62. 
sociedade tenha uma "certa quantidade de livre movimento" 12 e, segundo, conforme uma tradicional concepção do constitucionalismo, assegurar que haja participação do povo no exercício do Poder. A questão, assim, não é a extensão em que a noção de Poder exibe características análogas à do dinheiro, como propôs Parsons no campo sociológico, mas em que medida o Poder que se exerce por meios financeiros se identifica com os limites constitutivos de seu exercício.

Uma Constituição tem, sinteticamente, em relação ao exercício do Poder, duas questões fundamentais para resolver: a primeira, quem o exerce; a segunda, se haverá limites. ${ }^{13}$ Para responder à primeira questão, a Constituição brasileira optou pela Democracia, ao dispor que todo o poder emana do povo (art. $1^{\circ}$, parágrafo único). Para responder à segunda, prescreveu um Estado de Direito (art. $1^{\circ}$, caput) com poderes harmônicos e independentes (art. $2^{\circ}$ ) e direitos e garantias fundamentais .

Neste sentido, num Estado Democrático de Direito o poder financeiro se identifica com o próprio poder do Estado, conformado em suas possibilidades e limitações. É necessário que as decisões constitucionais fundamentais estabeleçam a forma de legitimação do exercício deste Poder, e fica claro que os limites aí estabelecidos se aplicam também à obtenção e ao uso dos meios financeiros. Cabe, entretanto, a cada sistema constitucional concreto caracterizar o direito financeiro em seus aspectos peculiares, em razão do próprio significado político da organização financeira do Estado. ${ }^{14}$

\subsubsection{A organização das finanças públicas}

O termo "organização" é aqui utilizado como a atividade que se destina a criar, alterar ou extinguir as unidades pelas quais o Estado age, além de lhes conferir poder e

\footnotetext{
${ }^{12}$ MAYER, Otto. Kleine Schriften zum Öffentlichen Recht. Berlim: Duncker \& Humblot, 1981, p. 368-9, v. 1.

${ }^{13}$ VOGEL, Klaus. Der Finanz- und Steuerstaat. In: ISENSEE, J.; KIRCHHOF, P. (ed.). Handbuch des Staatsrechts. $3^{\text {a }}$ ed. Heidelberg: C. F. Müller Verlag, 2004, p. 854, v. 2.

${ }^{14}$ VIDIGAL, Geraldo. Fundamentos de Direito Financeiro. São Paulo: Revista dos Tribunais, 1973, p. 165-6.
} 
estabelecer relações entre elas $^{15}$. Estas unidades de ação são juridicamente estabelecidas, mas há uma grande e significativa diferença entre a existência de alguma unidade de ação do Estado e a provisão de recursos para sua atuação. Como o dinheiro é uma forma de exercício do Poder, a organização jurídica das unidades de ação do Estado deve ser completada pelos recursos financeiros à sua disposição ${ }^{16}$. Disso dependem sua atividade e a extensão de suas competências. Assim, além da competência normativa conferida a estas unidades de ação, é jurídica e politicamente importante que elas tenham também a competência de obter recursos e de gastá-los até certos limites - e chame-se isto de competência financeira.

O direito constitucional brasileiro vigente, a exemplo do de outros países, distribui, no plano constitucional, competências financeiras. Aos entes da federação, dotados de competência tributária, foram atribuídas receitas próprias, assim como encargos. Nos limites destas competências constitucionais se encontra o campo em que se tomam decisões financeiras, tradicionalmente por meio do orçamento público. Neumark aponta como uma das condições da elaboração do orçamento a existência de uma comunidade política que disponha sobre receitas e despesas. ${ }^{17}$

O fato, todavia, é que utilizar o orçamento como espaço livre de disposição de meios para distribuir recursos (e, portanto, poderes) entre os diversos entes administrativos constitui uma possibilidade, hoje, mais limitada. Grande parte dos recursos orçamentários anualmente disponíveis é vinculada a finalidades determinadas previamente, por normas constitucionais ou infraconstitucionais. Assim, a importância da "massa disponível" 18 de recursos é, em diversos sistemas jurídico-orçamentários, cada vez mais reduzida.

\footnotetext{
${ }^{15}$ BÖCKENFÖRDE, Ernst-Wolfgang. Die Organisationsgewalt im Bereich der Regierung: eine Untersuchung zum Staatsrecht der Bundesrepublik Deutschland. Berlin: Duncker \& Humblot, 1964, p. 29.

${ }^{16}$ VOGEL, Klaus. Der Finanz- und Steuerstaat. In: ISENSEE, J.; KIRCHHOF, P. (ed.). Handbuch des Staatsrechts. $3^{\text {a }}$ ed. Heidelberg: C. F. Müller Verlag, 2004, p. 855, v. 2.

${ }^{17}$ NEUMARK, Fritz. Der Reichshaushaltplan: ein Beitrag zur Lehre vom Öffentlichen Haushalt. Jena: Gustav Fischer, 1929, p. 12. O autor faz a ressalva de que não importa se essa comunidade política chega ou não a constituir um Estado no sentido moderno. Isto porque, para Fritz Neumark, o orçamento é um conceito eminentemente financeiro, e não jurídico. O que significa dizer: poderá existir orçamento mesmo onde não haja forma jurídica que o discipline. Os orçamentos modernos, elaborados por meio de atos normativos, são apenas uma forma histórica de manifestação do fenômeno orçamentário.

${ }^{18}$ KRÜGER-SPITTA, Wolfgang; BRONK, Horst. Einführung in das Haushaltsrecht und die Haushaltspolitik. Darmstadt: Wissenschaftliche Buchgesellschaft, 1973, p. 30.
} 
Se o emprego de dinheiro por meio do orçamento público, por um lado, influencia a atividade estatal, haveria, porém, certo excesso em qualificar o orçamento como a expressão absoluta do programa político de ação do governo. A própria limitação do orçamento ao período do exercício financeiro faz com que sua capacidade de direção da administração e orientação da sociedade seja de alguma forma limitada. Há, na atualidade, outros instrumentos adicionais para o planejamento, os quais permitem a direção da administração por meio do emprego de dinheiro. O orçamento é uma fase de diversos processos de decisão política financeira ${ }^{19}$. Todavia, como se pode observar no caso brasileiro, muitas das grandes expectativas depositadas em instrumentos de planejamento plurianual não se concretizaram ${ }^{20}$, e a indicação dos montantes de recursos nos orçamentos continua a ser determinante para a ação do governo e a indicação das decisões políticas governamentais para a sociedade.

Embora a instituição orçamentária seja dinâmica e se transforme conforme a atividade financeira do Estado absorva novos métodos de gestão, permanece a necessidade de limitação do poder financeiro: o orçamento público é condicionado à regulação constitucional da vida política. ${ }^{21} \mathrm{Em}$ termos práticos, isto significa que a criação do orçamento depende da existência de um órgão representativo parlamentar e de restrições às competências do Poder Executivo sobre questões financeiras e orçamentárias, que apenas podem ser exercidas pelas vias constitucionalmente admitidas.

Como quer Klaus Vogel, a competência para dispor de dinheiro não é constitucionalmente menos importante que a competência normativa de instituir proibições, permissões ou deveres. ${ }^{22}$ É significativo que, no século XIX, as disputas políticas pelo controle do Parlamento sobre o Executivo se tenham dado, inicialmente,

\footnotetext{
${ }^{19}$ No caso brasileiro, por exemplo, o Plano Plurianual e a Lei de Diretrizes Orçamentárias.

${ }^{20}$ CARDOSO Jr., José Celso. Planejamento Governamental e Gestão Pública no Brasil: elementos para ressignificar o debate e qualificar o Estado. Brasília: IPEA, 2011, p. 49 e ss.

${ }^{21}$ NEUMARK, Fritz. Der Reichshaushaltplan: ein Beitrag zur Lehre vom Öffentlichen Haushalt. Jena: Gustav Fischer, 1929, p. 15.

22 "Die Zuständigkeit, über Geld zu verfügen, ist verfassungsrechtlich nicht weniger bedeutsam als die Zuständigkeit, Gebote zu erlassen, von Geboten freizustellen oder Zuständigkeiten zum Erla $\beta$ oder zur Freistellung von Geboten zu übertragen" (VOGEL, Klaus. Der Finanz- und Steuerstaat. In: ISENSEE, J.; KIRCHHOF, P. (ed.). Handbuch des Staatsrechts. $3^{\text {a }}$ ed. Heidelberg: C. F. Müller Verlag, 2004, p. 858, v. 2).
} 
no campo da obtenção de recursos e dos primeiros tipos de orçamento ${ }^{23}$. A necessidade de autorização parlamentar para a obtenção e o dispêndio de recursos precede, historicamente, a necessidade de lei para atingir a liberdade ou a propriedade dos cidadãos $^{24}$. Também Duverger identifica que o poder financeiro dos Parlamentos, na origem da instituição, foi mais importante que seu poder legislativo: as Assembleias consentiam a tributação (no taxation without representation) antes mesmo que votassem leis $^{25}$. Na literatura sobre o orçamento o controle parlamentar sempre está em primeiro plano.

\subsubsection{A separação constitucional dos poderes financeiros}

Estabelecido que o Estado desempenha função financeira e que seu exercício se organiza principalmente por um instrumento - o orçamento público - que se caracteriza como meio de controle político ${ }^{26}$ do Parlamento sobre o Executivo, cabe situar aquela função no quadro de separação de poderes do Estado. Mas não sem antes considerar que as disposições constitucionais relativas à atividade financeira do Estado não se deixam enquadrar perfeitamente em qualquer esquema tripartite estanque.

Como afirmou Gerhard Wacke, a Constituição Financeira tem valor constitucional em si mesma ${ }^{27}$. A "função financeira" do Estado se posiciona de maneira independente ao lado de outras: a legislativa, a administrativa e a jurisdicional ${ }^{28}$. Não se trata, porém, de uma "quarta função" do Estado, mas de uma "relação de condicionamento

\footnotetext{
${ }^{23}$ Cf. BALEEIRO, Aliomar. Uma Introdução à Ciência das Finanças. $15^{\mathrm{a}}$ ed. Rio de Janeiro: Forense, 1998, p. 388 e ss.; BEREIJO, Alvaro R. Estudio preliminar. In: LABAND, Paul. Derecho presupuestario. Madrid: Instituto de Estudios Fiscales, 1979.

${ }^{24}$ MUßGNUG, Reinhard. Der Haushaltsplan als Gesetz. In: FORSCHUNGSGESELLSCHAFT FÜR STAATS- UND KOMMUNAL WIRTSCHAFT. Studien der Forschungsgesellschaft für Staats- und Kommunalwirtschaft e.V. $1^{\text {a }}$ ed. Frankfurt a.M.: Schwartz, 1976. v. 6, p. 379-393.

${ }^{25}$ DUVERGER, Maurice. Institutions Politiques et Droit Constitutionnel. $11^{\mathrm{a}}$ ed. Paris: Presses Universitaires de France, 1970, p. 791.

${ }^{26}$ Embora não se trate de sua única característica, ressalte-se.

${ }^{27}$ WACKE, Gerhard. Das Finanzwesen der Bundesrepublik: die Einwirkungen der Finanzfunktion auf Gesetzgebung, Verwaltung und Rechtssprechung im Bonner Grundgesetz. Tübingen: J. C. B. Mohr, 1950, p. 14.

${ }^{28}$ A classificação das funções do Estado leva em conta, aqui, o critério da atividade desempenhada, definida como um complexo ordenado de atos destinados a um fim (MIRANDA, Jorge. Manual de Direito Constitucional. $3^{\mathrm{a}}$ ed. Coimbra: Coimbra Editora, 2004, tomo V, p. 11).
} 
recíproco" ${ }^{29}$, pois a função financeira, de um lado, depende da atuação das demais e, de outro lado, é uma "condição necessária para a atividade de todas as outras três funções estatais" "30. Se é possível extrair consequências desta posição especial da Constituição Financeira, é algo que Wacke deixa em aberto, mas aponta que seu significado jurídicoconstitucional ainda é pouco conhecido ${ }^{31}$.

Como a arrecadação de recursos é uma condição fundamental do Estado contemporâneo, porque o poder estatal e as funções que deve desempenhar dependem do emprego de meios financeiros, consequência inafastável é que a legiferação, a jurisdição e a administração do Estado dependem da disponibilidade de dinheiro. A função financeira do Estado circunda, pois, a todas as outras. Ela não deixa de ser, contudo, uma parte do poder estatal, cujo exercício, segundo o art. $2^{\circ}$ da Constituição Federal, se distribui entre os poderes Executivo, Legislativo e Judiciário. A função financeira deve se manifestar e ser executada, consequentemente, na forma administrativa, legislativa ou jurisdicional que compita, sem caráter de exclusividade, a cada um dos Poderes. Pelo que, em cada situação, as particularidades da atividade financeira devem a eles se adaptar. Tem razão, portanto, Wacke, quando se recusa a classificar a função financeira como uma quarta função, vendo-a como uma interpenetração recíproca das demais funções estatais.

Por isso é comum que constituições, no âmbito financeiro como em outros, não se restrinjam apenas a um modelo tanto clássico quanto hoje inexistente de separação estanque de Poderes, mas tragam, também, formas de sua aproximação ${ }^{32}$. Esta aproximação não significa o alijamento de diferenças funcionais. Trata-se, antes, da colaboração entre os Poderes para a consecução de determinada finalidade, de modo a obter ganhos de eficiência e controle. Isto se demonstra já numa primeira aproximação do tema, ao se constatar que as competências relacionadas ao ciclo de elaboração,

\footnotetext{
${ }^{29}$ WACKE, Gerhard. Das Finanzwesen der Bundesrepublik: die Einwirkungen der Finanzfunktion auf Gesetzgebung, Verwaltung und Rechtssprechung im Bonner Grundgesetz. Tübingen: J. C. B. Mohr, 1950, p. 13. Em sentido contrário, cf. HÖPKER-ASCHOFF, Hermann. Das Finanzwesen der Bundesrepublik, Bemerkungen zu dem Buch von G. Wacke. Finanzarchiv, Tübingen, v. 12, 1950/51, p. 725-9.

${ }^{30}$ WACKE, Gerhard. Das Finanzwesen der Bundesrepublik: die Einwirkungen der Finanzfunktion auf Gesetzgebung, Verwaltung und Rechtssprechung im Bonner Grundgesetz. Tübingen: J. C. B. Mohr, 1950, p. 14.

${ }^{31}$ WACKE, Gerhard. Das Finanzwesen der Bundesrepublik: die Einwirkungen der Finanzfunktion auf Gesetzgebung, Verwaltung und Rechtssprechung im Bonner Grundgesetz. Tübingen: J. C. B. Mohr, 1950, p. 14.

${ }^{32}$ DI FABIO, Udo. Gewaltenteilung. In: ISENSEE, J.; KIRCHHOF, P. (ed.). Handbuch des Staatsrechts. $3^{\text {a }}$ ed. Heidelberg: C. F. Müller Verlag, 2004. v. 2, p. 628.
} 
aprovação, execução e do controle do orçamento, explícita ou implicitamente, pertencem tanto ao Poder Executivo como ao Legislativo. A análise destas diferentes competências é necessária para que se possam analisar, com maior clareza, os papeis desempenhados por estes poderes no ciclo orçamentário e, no limite, quem manda no orçamento público.

\subsubsection{Distribuição de competências no ciclo orçamentário: duas tradições}

As atividades orçamentárias do Estado ocorrem dentro de períodos que se repetem e que se caracterizam pelas etapas de elaboração da proposta de orçamento, aprovação da lei de orçamento, execução do orçamento e controle da execução orçamentária. As competências pertinentes a cada uma destas fases constituem funções orçamentárias, como a elas se refere José Afonso da Silva ${ }^{33}$.

A observação do ciclo orçamentário permite considerar que as competências orçamentárias se repartem entre os Poderes Executivo e Legislativo e que, portanto, o orçamento público é o resultado da atuação conjunta e equilibrada destes Poderes. Algumas destas competências, porém, não são explícitas na Constituição Federal, que em nenhum momento define, expressamente, qual dos Poderes tem competência para executar o orçamento - tema do qual se tratará após o enquadramento de duas questões centrais na distribuição de competências no ciclo orçamentário: quem elabora o orçamento e, depois de aprovada a proposta governamental, quais são os efeitos desta aprovação.

Estas questões mostram-se essenciais para a atribuição da competência de executar o orçamento em razão da prevalência de duas posições dominantes sobre o assunto. A primeira delas centra-se no argumento da eficiência, ao vislumbrar no governo, e não no parlamento, as condições técnicas de dispor das informações necessárias para elaborar a proposta - o que tem por consequência, invariavelmente, a extensão automática desta consideração à fase de arrecadação e gasto dos recursos previstos. A segunda delas, juridicamente de maior relevância, diz respeito ao caráter

\footnotetext{
${ }^{33}$ SILVA, José Afonso da. Orçamento-Programa no Brasil. São Paulo: Revista dos Tribunais, 1973, p. 230 .
} 
exclusivamente autorizador do ato aprovado pelo Poder Legislativo, o qual, assumindo ou não a forma de lei, não teria aptidão para gerar efeitos jurídicos típicos de normas gerais e abstratas, por constituir ato materialmente administrativo - o que significa dizer que as decisões tomadas na fase de execução orçamentária somente o podem ser pelo Poder Executivo.

A primeira destas posições aqui chamadas dominantes desenvolveu-se com maior clareza nas discussões políticas norte-americanas sobre a transferência, para o Poder Executivo, da competência de elaborar o orçamento público e também de executá-lo, por ser necessário, nesta fase, o exercício de uma competência administrativa, neutra e não política. A segunda delas, na teoria de Paul Laband sobre a peculiar natureza jurídica do orçamento. Ambas tiveram seu contexto e seu momento, mas continuam a influenciar os debates sobre o tema, muitas vezes em detrimento da disciplina constitucional do orçamento público.

\subsubsection{Uma tradição: o orçamento do Executivo e a purificação da política}

Chega mesmo a ser um truísmo do pensamento político a afirmação de que o cerne da autoridade legislativa está naquilo que Fenno denominou de "o poder da bolsa" 34 , caracterizado pelo controle exercido pelo Parlamento sobre a atividade financeira do Estado.

A noção de controle parlamentar reavivou-se nas Revoluções Francesa e Americana, dando feição moderna à tendência de controle orçamentário do soberano impulsionada já pela Magna Charta (1215) e pela Petition of Rights (1628) ${ }^{35}$. A tal ponto que o orçamento foi deixado a cargo do Legislativo em países como a França, logo após a fixação do Novo Regime, e os Estados Unidos da América, até a data historicamente recente de 1921, quando ali foi empreendida talvez uma das mais relevantes reformas da distribuição do poder financeiro, o Budget and Accounting Act.

\footnotetext{
${ }^{34}$ FENNO, R. The Power of the Purse: Appropriations Politics in Congress. Boston: Little Brown, 1966.

${ }^{35}$ Para mais detalhada reconstituição histórica das características destas instituições, cf. BALEEIRO, Aliomar. Uma Introdução à Ciência das Finanças. 15ª ed. Rio de Janeiro: Forense, 1998, p. 388 e ss.
} 
O orçamento elaborado pelo Poder Legislativo teve seus princípios fortemente atacados, em razão de novas necessidades concretas da atividade financeira, e também pela perspectiva conceitual de que elaborar o orçamento consiste em atividade técnica impossível de ser realizada em parlamentos, marcados pelo poder dos chefes de partidos e pela preferência por interesses locais em detrimento da preocupação com o interesse nacional. Tornou-se relevante, então, a noção de orçamento do Executivo.

Orçamentos do Executivo e do Legislativo, assim tomados à primeira vista, são termos que podem implicar denotações errôneas. Eles não devem indicar que o orçamento em cada um dos casos é feito apenas pelo trabalho do Executivo ou do Legislativo, mas, isto sim e apenas, que em ambos os casos cada um dos poderes tem a prerrogativa da elaboração da proposta orçamentária.

No caso do orçamento do Executivo, tem o referido Poder a iniciativa orçamentária em sentido estrito, isto é, a competência para estabelecer, de maneira independente, a proposta de orçamento, que o Parlamento tomará como fundamento e orientação. Neste caso, tem pouca importância se o Poder Legislativo pode, em determinadas circunstâncias, alterar partes desta proposta, pois mesmo estas alterações se prestam a modificar o projeto inicial, que lhes serve de referência. Isto significa que o Poder Executivo é o órgão com poder de iniciativa legislativa regularmente responsável pela elaboração do projeto orçamentário.

No caso de um orçamento do Legislativo, este Poder tem a responsabilidade exclusiva por elaborar o projeto. Comumente são-lhe comunicadas estimativas e demonstrativos pela Administração, mas a estes não fica o Parlamento vinculado. Isto pela preocupação com a tirania do governo e com a legitimidade democrática da representação popular no Poder Legislativo, como depositário da vontade de todo o povo, e não apenas da maioria. Observa-se esta preocupação, por exemplo, na ocasião em que o primeiro secretário do Tesouro norte-americano, Alexander Hamilton, expressou ao Congresso sua opinião sobre quais os melhores caminhos a seguir na criação do Departamento do Tesouro. Este exercício da opinião, por si, levantou a suspeita de que o secretário estava demasiadamente preocupado em fortalecer o próprio poder - foi censurado no sentido de que deveria se restringir a encaminhar o projeto e 
não influenciar o Congresso ${ }^{36}$. A proposição de um orçamento do Legislativo é, então, elaborada e votada pelo Parlamento ou, na prática destes casos, pela Comissão responsável pela elaboração do Orçamento. A iniciativa é de competência privativa do Poder Legislativo.

Mas de maneira predominante passou-se a admitir, com fundamentos teóricos e práticos, que a elaboração da proposta orçamentária deve ser matéria de competência privativa do chefe do Poder Executivo. A razão para a preferência desta solução encontra diferentes justificativas conforme o tempo e o lugar. Fritz Neumark menciona que estas fundamentações se dão na direção de duas orientações principais (e que nem sempre combinam): uma, filosófico-constitucional, referente ao papel dos Poderes do Estado; outra, político-técnica, relativa ao bom funcionamento de suas finanças ${ }^{37}$.

A primeira orientação é inicialmente representada pelos argumentos do visconde de Chateaubriand, segundo quem as Câmaras Legislativas não devem ter a prerrogativa de elaborar a proposta orçamentária porque "a formação do orçamento pertence essencialmente à prerrogativa real” e o Parlamento é apenas o "juiz do orçamento". 38 Ainda, se as Câmaras Legislativas fazem o orçamento, seria ilógico que pudessem exigir prestação de contas da sua própria obra, e o administrador que executa o orçamento, por não ser responsável por determinar os rumos da atividade financeira, deixa de ser responsável pela parte de maior importância da Administração ${ }^{39}$. Um orçamento do Legislativo, deste modo, representaria um desvio na repartição constitucional dos poderes, pois faria com que o Legislativo perdesse a prerrogativa da fiscalização e o Executivo não mais tivesse responsabilidade pela administração das finanças do Estado.

No fundo da argumentação de Chateaubriand em favor da iniciativa executiva subjaz a ideia de que é necessário fazer que o governo tenha responsabilidade. Esta responsabilidade para de existir se a proposta orçamentária surge do Parlamento. O argumento extrapolou as fronteiras da França e fez-se bastante presente nos debates

\footnotetext{
${ }^{36}$ WILDAVSKY, A.; CAIDEN, D. The New Politics of the Budgetary Process. $5^{\text {a }}$ ed. New York: Pearson Longman, 2004, p. 26.

${ }^{37}$ NEUMARK, Fritz. Der Reichshaushaltplan: ein Beitrag zur Lehre vom öffentlichen Haushalt. Jena: Verlag von Gustav Fischer, 1929, p. 58-9.

${ }^{38}$ CHATEAUBRIAND, F-R. De la Monarchie selon la Charte. Paris: Normant, 1826, p. 55-7, tradução livre.

${ }^{39}$ CHATEAUBRIAND, F-R. De la Monarchie selon la Charte. Paris: Normant, 1826, p. 55-7, tradução livre.
} 
norte-americanos sobre a reforma orçamentária, desempenhando um papel central. A luta pela instituição de um orçamento propriamente do Executivo para o governo federal dos Estados Unidos foi feita sob o mote de combater o desperdício dos meios financeiros por comissões legislativas irresponsáveis. Propugnou-se a restauração de um governo responsável ${ }^{40}$.

Ao lado deste argumento de índole filosófico-constitucional, foram acrescentadas fundamentações pragmáticas para a reforma orçamentária norteamericana. Estas razões, hoje, assumem ares de obviedade, tamanha sua influência. Como acentuou Stein ${ }^{41}$,

(...)somente o Governo pode ter esta iniciativa [de elaborar a proposta orçamentária]. Porque somente ele possui as condições necessárias, as quais somente ele pode administrar e usar de maneira capaz, de conhecer todas as receitas e todas as necessidades da vida estatal (...). Para cada lei financeira individual a iniciativa da representação popular é admissível; para o orçamento como um todo ela é simplesmente impossível.

Acontece que, apesar de terem se consolidado como uma evidência, tais considerações foram praticamente ignoradas na prática orçamentária dos Estados Unidos da América até 1921. A experiência desta nação mostrava, diziam os defensores de um orçamento do Executivo, que a preparação de uma previsão orçamentária por um Parlamento demasiadamente influenciado pelos chefes de partido pode conduzir à irresponsabilidade diante de escolhas públicas que precisam ser feitas com cada vez mais freqüência em razão da expansão das atividades estatais. Adepto desta corrente, Neumark considerou que "os representantes populares não podem, em nenhuma circunstância, ter o conhecimento específico que possui a burocracia e sem o qual não se governa num Estado moderno" 42 .

O movimento do orçamento do Executivo nos Estados Unidos da América deve ser compreendido como um ataque ao modus operandi fragmentado do processo orçamentário. Se a ideia original do orçamento do Legislativo era ser o mais potente freio e contrapeso ao Executivo, viu-se surgir o "poder irresponsável" de chefes de partido e presidentes de comissões congressuais que tinham poucas responsabilidades sobre o produto de sua atividade. Os reformadores orçamentários, longe de serem

\footnotetext{
${ }^{40}$ Cf. FITZPATRICK, E. A. Budget Making in a Democracy. New York: Macmillan, 1918.

${ }^{41}$ STEIN, L. Lehrbuch der Finanzwissenschaft. $5^{\text {a }}$ ed., Leipzig, 1885, p. 208, v. 1, tradução livre.

${ }^{42}$ NEUMARK, Fritz. Der Reichshaushaltplan: ein Beitrag zur Lehre vom öffentlichen Haushalt. Jena: Verlag von Gustav Fischer, 1929, p. 58 e ss.
} 
radicais que se opusessem à estrutura social do poder político norte-americano, desejavam, isto sim, que o orçamento fosse elaborado por um Executivo democraticamente controlável. Os defensores desta propostas autointitularam-se como os establishment's antiestablishment ${ }^{43}$.

Outro aspecto desta corrente torna a discussão diretamente relevante ao tema da execução orçamentária. Isto porque os reformadores faziam uma de suas maiores objeções à especificação das despesas, contrários que eram a esta prática limitadora da discricionariedade do Executivo. Expor as despesas orçamentárias em itens específicos (line-item budget) acarretava excessiva rigidez da execução e não permitia sua adaptação às circunstâncias ${ }^{44}$. Mas é preciso situar corretamente esta crítica: não parece que o problema da especificação estivesse em si mesma, mas no fato dela ser promovida de maneira desarticulada por parlamentares que detalhavam arbitrariamente as despesas sem o adequado conhecimento das reais necessidades da administração. O cumprimento de um orçamento elaborado nestas circunstâncias tinha pouco sentido para uma ação planejada e articulada do governo.

Não é possível, a propósito, deixar de considerar a objeção de que é bastante provável que o governo elabore a proposta orçamentária não apenas com base em dados técnicos possuídos pela burocracia, mas premido por pressões econômicas e ideológicas, além de interesses do grupo que representa. Tudo isso é um forte fator de influência sobre as decisões orçamentárias, e parece irreal, nestes termos, a ideia de que o Executivo seria alvo menos frequente de grupos de interesse e pressões setoriais. Em todo caso, a doutrina do orçamento do Executivo argumenta que estes grupos de interesse podem ser representados mais generalizadamente, e administrados como um conjunto, no âmbito interno do governo - estrutura hierarquizada em cadeias de comando, e não de maneira individual e localizada de acordo com cada uma das regiões eleitorais dos inúmeros parlamentares que compõem o Poder Legislativo, formando um espectro não administrável de pressões as mais incoerentes ${ }^{45}$. A concentração de prerrogativas orçamentárias no Executivo permitiria o controle e a articulação do caos

\footnotetext{
${ }^{43}$ WILDAVSKY, A.; CAIDEN, D. The New Politics of the Budgetary Process. $5^{\mathrm{a}}$ ed. New York: Pearson Longman, 2004, p. 33.

${ }^{44}$ WILDAVSKY, A.; CAIDEN, D. The New Politics of the Budgetary Process. $5^{\mathrm{a}}$ ed. New York: Pearson Longman, 2004, p. 33.

${ }^{45}$ NEUMARK, Fritz. Der Reichshaushaltplan: ein Beitrag zur Lehre vom öffentlichen Haushalt. Jena: Verlag von Gustav Fischer, 1929, p. 58 e ss.
} 
das pressões políticas e econômicas, à medida que sua administração é promovida por órgãos menos convulsos e mais organizados que um Parlamento. $\mathrm{O}$ compromisso com uma visão de conjunto permite, além disso, a obtenção de um desejado equilíbrio entre receitas e despesas, pois torna possível uma visão total do orçamento.

O movimento que pregou mais consistentemente a necessidade de um Orçamento elaborado pelo Executivo, nos Estados Unidos da América, postulou-a, assim, com o propósito de que a implementação da decisão orçamentária se tornasse um procedimento eminentemente técnico, como fica expresso na tese de Woodrow Wilson de que uma liderança concentrada no Executivo "purificaria a política". Mais especificamente, purificaria a política orçamentária, que deveria ser conduzida por "poucos homens de mente treinada e de acordo com princípios". Isto bastaria para conferir algum sentido racional à política orçamentária ${ }^{46}$.

Este raciocínio está muito distante de se circunscrever aos debates constitucionais norte-americanos. Ao contrário, tornou-se muito influente, principalmente para as ideias preponderantes sobre como se deve organizar a burocracia orçamentária estatal. Ele conduz, em última instância, à dicotomia entre política e administração presente em boa parte dos comentários feitos sobre a implementação da decisão orçamentária. Considera-se que a função do Parlamento é participar da decisão política geral, ao passo que a execução orçamentária seria um procedimento técnico de concretização e aplicação daquela decisão política mais abrangente previamente feita. A competência da Administração de executar o orçamento é, portanto, uma "competência neutra”, conceito cuja formulação é ocasionalmente atribuída a Goodnow, que acreditava que as duas funções primárias do governo são determinar a vontade do povo e executá-la ${ }^{47}$. Contrapunham-se estas duas funções (política e administrativa) à clássica tripartição dos Poderes. O autor esteve longe, porém, de fazer uma cisão estrita entre as duas atividades, quais sejam, a determinação da vontade estatal pela política e sua execução pela administração. É o que foi percebido por Dwight Waldo ao afirmar que interpretações menos sofisticadas da doutrina de Goodnow passaram a legitimar a diminuição de poder dos parlamentos e a transferi-lo ao Executivo e, em última

\footnotetext{
${ }^{46}$ WILSON, Woodrow. Congressional Government: a Study in American Politics. Boston: Houghton Mifflin, 1895, p. 180-1.

${ }^{47}$ GOODNOW, F. Politics and Administration: a Study in Government. New Brunswick, NJ: Transaction Publishers, 2003.
} 
instância, a seus técnicos e burocratas, os mais veementes defensores do orçamento do Executivo $^{48}$.

Esta cisão entre Administração (corporificada no Poder Executivo) e a Política (localizada no Poder Legislativo) serviu para incentivar a noção de uma hierarquia orçamentária, pela qual o Poder Executivo é o principal agente do ciclo orçamentário. Ao Legislativo corresponderiam funções externas de controle (ou o controle do projeto por meio de sua votação, ou o controle da execução), mas não a interferência na decisão política orçamentária - uma prerrogativa governamental. Um expediente britânico acorreu a esta teorização de tanta influência prática. Na Grã-Bretanha, a única ferramenta à disposição do Parlamento para mudar o orçamento seria mudar o Governo, sem que se pudesse determinar, entretanto, o que o Governo deveria ou não fazer. Willoughby ${ }^{49}$ escorou-se neste sistema ao formular que,

\begin{abstract}
[s]e alguém olhar para o segredo do sistema inglês, ele deve ser encontrado na distinção clara entre os poderes legislativo e administrativo. Nenhuma proposta de despesa deve ser feita, exceto pelo gabinete que age como curador do poder administrativo do governo.
\end{abstract}

Fica claro o sentido de conferir à decisão orçamentária do Executivo o caráter de guia de todo o sistema de organização do poder financeiro. Por esta lógica, presume-se que, depois que as despesas ganharam a aprovação presidencial, ela representaria o interesse nacional e sobraria pouco espaço para a troca de favores no Congresso. Nem todas as vozes do tempo concordaram com este pensamento, como, por exemplo, Fitzpatrick, ao acidamente perguntar se os admiradores das prerrogativas governamentais inglesas a levariam às últimas consequências e chegariam a propor a possibilidade de recall do Executivo pelo Congresso ${ }^{50}$. Para ele, o nome "orçamento do Executivo" camuflou a verdadeira intenção de seus formuladores: uma fundamental transformação no sistema político de pesos e contrapesos.

Foi sob o comando do Presidente Taft que estas transformações foram institucionalizadas, por meio de famosa Comissão batizada com seu nome. Sua tarefa fundamental era fazer com que o presidente submetesse a estimativa das despesas ao

\footnotetext{
${ }^{48}$ WALDO, D. The Administrative State. New York: Ronald Press, 1948, p. 105-7.

${ }^{49}$ WILlOUGHBY, W. The Problem of a National Budget. New York: D. Appleton and Co., 1918, p. 5960, tradução livre.

${ }^{50}$ FITZPATRICK, E. A. Budget Making in a Democracy. New York: Macmillan, 1918, p. 55.
} 
Congresso e assumisse responsabilidade por ela. Além disso, a Comissão Taft rejeitou a visão então prevalecente de que os gastos deveriam ser os menores possíveis e advogou que o governo deveria ter maiores operações econômicas ${ }^{51}$. Conforme Wildavsky, este aumento do poder do presidente recebeu um nome difícil de contradizer: eficiência ${ }^{52}$. Não foi, porém, até o final da Primeira Guerra Mundial que se fez alguma coisa para estabelecer um orçamento do Executivo naquele país ${ }^{53}$.

Se apenas o Poder Executivo tem condições técnicas e neutralidade política suficiente para definir os rumos da atividade financeira, com maior razão se pode definir que é a este Poder que compete a execução orçamentária. Isto porque a execução seria a fase administrativa por excelência do ciclo orçamentário, quando a Administração Pública aplica os recursos estabelecidos no orçamento aprovado pelo Poder Legislativo. Qualquer tentativa tomada pelo Congresso para se imiscuir nesta fase seria não apenas vista como indesejável do ponto de vista administrativo, pois o Poder Legislativo pouco entende de administração, como também inconstitucional, por violar uma fundamental separação de poderes legislativo e administrativo. E sendo a decisão de como executar o orçamento uma decisão eminentemente administrativa, não cabe ao Poder Legislativo interferir nesta fase. Estas são algumas decorrências lógicas que se podem depreender da doutrina do orçamento do Executivo, Poder a quem compete a elaboração e a execução orçamentárias. Ocorre que tais decorrências lógicas são desmentidas pela necessidade de aprovação legislativa da suplementação de recursos, o que demonstra contínua necessidade de discussão política durante a fase de execução, e, já em época mais recente, nos próprios Estados Unidos da América, pelo necessário consentimento do Congresso ao contingenciamento de recursos, em razão de abusos observados neste âmbito. Não é, portanto, com absoluta precisão que se pode defender a competência exclusiva do Poder Executivo para executar o orçamento com fundamento em alguma ideia apriorística de uma natural e insuprimível aptidão porque, embora o exercício específico da função administrativa permaneça como um dos fundamentos da separação de funções do Estado, tal noção não deve vir a impedir, à luz da atual estrutura constitucional, o afastamento do Parlamento da fase de execução orçamentária. A idéia original do orçamento do Executivo já apresenta diversas mitigações em seu próprio

\footnotetext{
${ }^{51}$ BURKHEAD, Jesse. Government Budgeting. New York: Wiley, 1956, p. 119.

${ }^{52}$ WILDAVSKY, A.; CAIDEN, D. The New Politics of the Budgetary Process. $5^{\mathrm{a}}$ ed. New York: Pearson Longman, 2004, p. 37.

${ }^{53}$ BURKHEAD, Jesse. Government Budgeting. New York: Wiley, 1956, p. 20-1.
} 
berço. O desenvolvimento desta posição, porém, necessita ser complementado, porém, por outras considerações.

\subsubsection{Outra tradição: o orçamento como lei meramente formal}

A opinião de que o orçamento público não teria mais que um caráter autorizador, isto é, que não consistiria senão na autorização conferida pelo Poder Legislativo ao Executivo para gastar até determinado limite, teve sua primeira e mais sólida formulação no "Direito Orçamentário" (1871) de Paul Laband ${ }^{54}$, e a partir daí perdura nas considerações sobre o tema. Novamente, a conseqüência mais imediata desta teoria para a fase de execução orçamentária, como se verá, é que, após a aprovação do orçamento pelo Poder Legislativo, cabe ao Poder Executivo tomar as decisões sobre sua execução, que é matéria de sua exclusiva competência. Sua responsabilidade perante o Parlamento é política e do orçamento não se podem extrair efeitos vinculantes. ${ }^{55}$

Apesar desta posição também apresentar variações, o argumento se concentra na separação constitucional dos Poderes Executivo e Legislativo. O primeiro detém, em alguma medida, autonomia e independência para exercer responsabilidades própria e especificamente governamentais. Correspondentemente, as competências constitucionais orçamentárias são delimitadas de modo a incluir a execução orçamentária no âmbito de competências do Poder Executivo, sem que, nesta fase, haja a previsão de colaboração do Poder Legislativo. Finalmente, a isto se acrescenta o argumento pragmático de que não depende do governo efetuar a arrecadação nos montantes previstos no orçamento, e, portanto, não pode estar obrigado a realizar as despesas nos volumes especificados porque isto depende do comportamento da receita $^{56}$.

Esta argumentação se associa à doutrina predominante a respeito da natureza jurídica do orçamento, segundo a qual este é lei somente em sentido formal, e não em

\footnotetext{
${ }^{54}$ Das Budgetrecht: Nach den Bestimmungen der Preussischen Verfassungs-Urkunde unter Berücksichtigung der Verfassung des Norddeutschen Bundes. Berlin: Verlag von J. Guttentag, 1871.

55 Cf. LABAND, Paul. Das Budgetrecht: Nach den Bestimmungen der Preussischen VerfassungsUrkunde unter Berücksichtigung der Verfassung des Norddeutschen Bundes. Berlin: Verlag von J. Guttentag, 1871.

${ }^{56}$ Cf. HOFFMAN, Reinhard. Haushaltsvollzug und Parlament. Tübingen: J. C. B. Mohr (Paul Siebeck), 1972 , p. 10
} 
sentido material. O orçamento contém previsões e programas repletos de estimativas, e não fatos objetivos. Não poderia, assim, estabelecer deveres jurídicos, além de não constituir norma de caráter geral e abstrato, com comandos jurídicos. Sendo um ato concreto, de caráter materialmente administrativo, pertence ao conjunto de atribuições do Poder Executivo.

\subsection{O anacronismo da doutrina dominante}

Sobre ser o orçamento lei, é isto o que, no caso brasileiro, estabelece a Constituição $^{57}$. A questão que permanece em outros sistemas não deve gerar polêmica no caso brasileiro, ao menos não neste sentido. Mas parar nesta consideração seria uma posição bastante insuficiente diante da rica discussão, já anunciada, sobre os efeitos jurídicos da lei orçamentária.

Em um dos primeiros trabalhos mais completos sobre o assunto, Jèze resumiu as opiniões no seguinte sentido: para uns, o orçamento é uma lei propriamente dita (Hönel, Vitagliano); para outros, ora é lei, ora é ato particular - um ato de administração (Duguit); e para um terceiro grupo, ainda, o orçamento nunca é uma lei (grande parte da doutrina alemã, francesa e italiana de então) ${ }^{58}$.

Alguns dos juristas brasileiros que começaram a tratar mais atentamente da questão da natureza jurídica do orçamento o definiram inicialmente como um "ato" de previsão e autorização da receita e da despesa pública para um período determinado ${ }^{59}$. $\mathrm{O}$ problema da persistência de definições nestes termos é que "ato" tem um sentido muito amplo e não deixa a questão mais clara.

As teorias mais formalistas do orçamento não concebem que seus efeitos jurídicos sejam os mesmos de uma lei em sentido material, razão pela qual ele seria, quando muito, lei em sentido formal. Nestes termos, as alterações pelas quais o orçamento deve passar ao longo do exercício não são um grande problema, pois,

\footnotetext{
${ }^{57}$ Caput do art. 165 da Constituição Federal.

58 JÈZE, G. Cours de Science des Finances et de Législation Financière Française. $6^{\mathrm{a}}$ ed. Paris: Marcel Giard, 1922, p. 23.

59 CAVALCANTI, Amaro. Elementos de Finanças: estudo teórico-prático. Rio de Janeiro: Imprensa Nacional, 1896, p. 527.
} 
obedecida determinada forma, não se trata nada além da alteração de um documento contábil que não tem efeitos gerais e abstratos como os de uma lei. E, afinal, se o orçamento aprovado consiste numa autorização, fica o Executivo autorizado a adotar as providências administrativas necessárias à execução desta lei. Neste sentido, quanto maior a proximidade de uma concepção formal do orçamento público, maior o espaço de flexibilidade de sua execução.

A partir do trabalho seminal de Laband, o sistema de controle do governo pelo orçamento alemão tomou caminhos bastante distintos em relação a outras nações. Isto porque este controle opera, geralmente, em dois caminhos. O primeiro é que o corpo legislativo se recuse, ou ameace recusar-se, a votar o orçamento; ou ainda, em situações nas quais ainda não se consolidou a idéia de um orçamento completo das receitas e despesas, que se negue a aprovar propostas específicas de criação de tributos ou de despesas. O poder de travar o governo é uma das primeiras formas de controle orçamentário. Um segundo caminho é normalmente o desenvolvimento do primeiro, e aparece em situações em que as competências orçamentárias do Parlamento já estão bem consolidadas: trata-se da crítica, da emenda, da rejeição de itens específicos ou de créditos adicionais, dentre outras possibilidades ${ }^{60}$.

Todavia, o sistema orçamentário alemão, inicialmente marcado pelos trabalhos de Rudolf von Gneist ${ }^{61}$ e depois fortemente influenciado por estudiosos como Laband e Jellinek, evoluiu de maneira fundamentalmente distinta. Ali, a possibilidade do Parlamento recusar propostas e solicitações orçamentárias do governo não foi compreendida como uma possibilidade constitucionalmente reconhecida. Esta distinção um tanto quanto artificial entre leis com caráter de lei propriamente dita e outras com caráter de ato administrativo mostrou-se bastante útil para tornar inócuo e inconstitucional o exercício, pelo Poder Legislativo, de alguma forma de participação nas modificações orçamentárias: se a matéria é de ato administrativo e os órgãos da administração decidiram pela necessidade de realizar as alterações, não poderia um

\footnotetext{
${ }^{60}$ Para uma visão mais detalhada destes sistemas, cf. SHEPARD, Walter James. The German Doctrine of the Budget. The American Political Science Review, Washington, v. 4, n. 1, fev. 1910, p. 52-54.

${ }^{61}$ Budget und Gesetz. Berlin: Springer, 1867.
} 
órgão externo recusá-la. Somente o conjunto de todos os sujeitos que participaram daquela decisão é que teriam competência para fazê-10 ${ }^{62}$.

Por isso não reconhece Jellinek ${ }^{63}$ a possibilidade de que o Legislativo use de suas competências para recusar a proposta orçamentária ou as necessidades de cobertura de despesas: o uso destas prerrogativas com finalidades políticas seria inconstitucional. Diz o jurista que

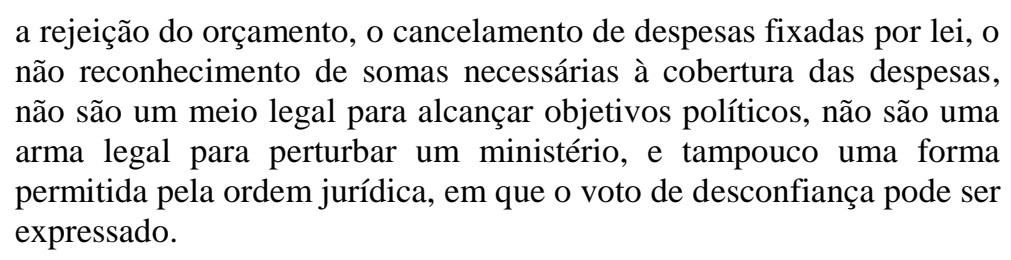

De outra parte, prosseguindo na dicotomia entre leis materiais e formais, que tanto tem influenciado a concepção jurídica do orçamento público, Laband ${ }^{64}$ argumenta que, em geral, o significado de uma lei consiste em conter comandos que, em cada caso concreto ao qual correspondam as hipóteses contidas no enunciado normativo, devem ser seguidos tanto pelas autoridades como pelos súditos do Estado. O orçamento não conteria de modo algum estas regras de caráter geral; já pelo seu conteúdo a lei de orçamento se diferencia de todas as outras leis.

Neste sentido, o orçamento poderia, de acordo com seu conteúdo, ser compreendido como lei ou, mais especificamente, como lex specialis, apenas em um único caso concreto, qual seja, a administração financeira do exercício físcal correspondente. A administração estatal geral do ano em questão, a respeito de seu aspecto financeiro, seria considerada como a efetivação desta lei especial. Quisesse-se aqui, porém, conferir verdadeira força de lei ao orçamento, então seria necessário entender que ele conteria uma obrigação de fazer e, adicionalmente, uma proibição para o governo. A obrigação: tomar medidas para que as receitas listadas no orçamento fossem arrecadadas no mesmo montante informado e que as despesas indicadas no orçamento também fossem executadas na mesma quantidade expressa. A proibição: arrecadar receitas e realizar despesas não orçadas.

\footnotetext{
${ }^{62}$ SHEPARD, Walter James. The German Doctrine of the Budget. The American Political Science Review, Washington, v. 4, n. 1, fev. 1910, p. 57-8.

${ }^{63}$ JELLINEK, G. Gesetz und Verordnung. Freiburg i. B.: Mohr, 1887, p. 289, tradução livre.

${ }^{64}$ LABAND, Paul. Das Budgetrecht: Nach den Bestimmungen der Preussischen Verfassungs-Urkunde unter Berücksichtigung der Verfassung des Norddeutschen Bundes. Berlin: Verlag von J. Guttentag, 1871, p. 52-53.
} 
Compreender os efeitos jurídicos da lei de orçamento desta maneira, porém, seria algo que, provavelmente, ainda não ocorreu a ninguém de maneira séria na prática constitucional, dizia Laband ${ }^{65}$. Porque em grande parte das dotações orçamentárias o montante é estabelecido apenas aproximadamente de acordo com cálculos parciais costumeiros. Seria então um sem-sentido obrigar legalmente a Administração a coletar as receitas e realizar as despesas sempre de acordo com o montante estimado. Da mesma maneira, ninguém gostará de encontrar na lei de orçamento uma proibição de arrecadar uma receita devida ao Estado porque ela não foi prevista, ou de economizar uma despesa para a qual o Estado alocou os meios.

De acordo com a teoria do orçamento como mera lei formal, pois, se se quisesse conferir à lei de orçamento realmente efeitos legais no sentido comum do termo, então seria necessário considerar todas as variações do orçamento como ilegais. Não somente as despesas adicionais como também as economias de despesas; não somente as deficiências nas receitas como também os seus superávits.

Mais importante, segundo esta concepção, é que o efeito jurídico do orçamento é apenas fazer com que a necessidade de recorrer a determinadas despesas seja reconhecida como um ato de concordância entre governo e parlamento. $\mathrm{O}$ orçamento teria, portanto, efeitos declaratórios, e não constitutivos, das necessidades que se procuram atender com suas dotações ${ }^{66}$.

Por mais que as teorias formalistas se tenham firmado no pensamento jurídico, porém, alguns questionamentos são inevitáveis.

Como seria possível conciliar a perspectiva do orçamento como lei meramente formal em face da realidade de muitos sistemas jurídicos que prevêm, por exemplo, a necessidade de autorização parlamentar para a decisão administrativa de não gastar as despesas previstas no orçamento? É o que leva Hoffman a qualificar de “inconsistente"67 a posição daqueles que, conquanto defendam a natureza jurídica

\footnotetext{
${ }^{65}$ LABAND, Paul. Das Budgetrecht: Nach den Bestimmungen der Preussischen Verfassungs-Urkunde unter Berücksichtigung der Verfassung des Norddeutschen Bundes. Berlin: Verlag von J. Guttentag, 1871, p. 53 e ss.

${ }^{66}$ LABAND, Paul. Das Budgetrecht: Nach den Bestimmungen der Preussischen Verfassungs-Urkunde unter Berücksichtigung der Verfassung des Norddeutschen Bundes, Berlin: Verlag von J. Guttentag, 1871 , p. 55.

${ }^{67}$ HOFFMAN, Reinhard. Haushaltsvollzug und Parlament. Tübingen: J. C. B. Mohr (Paul Siebeck), 1972, p. 14-5. A crítica dirige-se, por exemplo, a Fritz Neumark, que se expressa favoravelmente à
} 
formal da lei de orçamento - de efeitos meramente autorizadores, portanto -, se batem pela obrigatoriedade da execução de determinadas despesas de alta relevância política. Por exemplo, os recursos previstos para o funcionamento dos Poderes Legislativo e Judiciário, necessários que são ao funcionamento do Estado Democrático de Direito. Como ficará exposto em tópico específico sobre o contingenciamento de recursos, a necessidade de autorização legislativa para algumas hipóteses de contingenciamento ocorre, por exemplo, nos Estados Unidos da América e na Alemanha - o que demonstra o descompasso entre a teoria e a realidade que ela pretende descrever, no próprio berço de nascimento da teoria. No caso, as teorias da prerrogativa governamental da tomada de decisão financeira, expressas sob a forma de um orçamento do Executivo ou da natureza somente formal da lei de orçamento.

Do mesmo modo, ressente-se de uma fundamentação sistemática a opinião daqueles que defendem, concomitantemente, o caráter simplesmente autorizador do orçamento e a necessidade de submeter ao Parlamento os orçamentos retificativos, necessários à adoção de uma política econômica restritiva dos gastos orçamentários em face de uma redução da arrecadação que prejudique o equilíbrio orçamentário. ${ }^{68}$

Para o caso brasileiro, a concepção formalista da lei de orçamento levaria à conclusão de que qualquer alteração constitucional que transformasse alguns gastos em obrigatórios seria nula, pela intangibilidade do princípio da separação de Poderes. Não é esta, entretanto, uma conclusão aceitável, pois, de alguma forma, é a própria Constituição Federal que atribui ao Poder Legislativo a competência para participar da execução orçamentária, notadamente pela disciplina que confere a determinados instrumentos de flexibilidade, o que se demonstrará em capítulo posterior. Sobretudo, a Constituição Federal brasileira nada diz sobre competência privativa do Poder Executivo na fase de execução orçamentária - e, sendo o Poder Legislativo o Poder por excelência, em razão do princípio da soberania popular, não é possível que alguma competência privativa do Poder Executivo seja presumível. Ainda menos com base em duas ideias tomadas aqui como "tradições" do pensamento orçamentário, mas que de alguma forma já foram superadas nos próprios sistemas jurídicos de que se originaram e

execução obrigatória de "despesas importantes". (Cf. NEUMARK, Fritz. Der Reichshaushaltplan: ein Beitrag zur Lehre vom Öffentlichen Haushalt. Jena: Gustav Fischer, 1929, p. 121).

${ }^{68}$ Cf. VIALON, F. Haushaltsrecht. $2^{\mathrm{a}}$ ed. Berlin und Frankfurt a. M.: Franz Vahlen, 1959, p. 207. Ressalte-se que esta hipótese não encontra paralelo no direito brasileiro, por não se prever nem a existência de orçamentos retificativos nem a necessidade de que o Poder Legislativo aprove uma política de contenção de gastos adotada pelo Poder Executivo. 
que não podem ser imediatamente transportadas para o sistema constitucionalorçamentário brasileiro.

Estas são dificuldades colocadas à doutrina dominante de que o orçamento é lei apenas em sentido meramente formal, e não passa de um ato de autorização. Tal posição é por vezes referida por seus próprios apoiadores como uma tradição diretamente trazida do século XIX, como "especialmente conservadora" ou como "a Traditionskompanie da

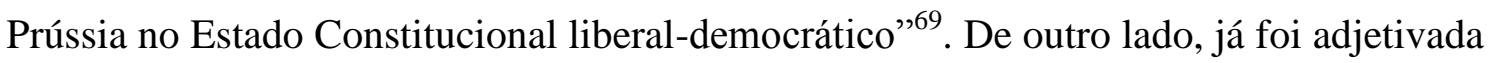
por seus críticos como "anacrônica" ou mesmo "antidemocrática",70. Em vista de sua tendência a enfraquecer os poderes parlamentares em estruturas constitucionais que reconhecem a democracia como regime de governo, chega a ser vista mesmo como um "fóssil constitucional"

Tal direito orçamentário conservador, por entender que o orçamento público pertence eminentemente aos interesses do Poder Executivo e foge do âmbito das competências parlamentares, não capta a importância constitucional que assume o Parlamento em diversos momentos do orçamento público. A colaboração parlamentar no orçamento demonstra que a lei orçamentária não faz parte exclusivamente da atividade material do Poder Executivo e, desta forma, não pode ser vista como uma anomalia $^{72}$. Sob o ponto de vista do orçamento como lei formal de caráter meramente autorizador, a participação do Parlamento na execução orçamentária é claramente tomada como inconstitucional: o Poder Executivo é um órgão constitucional independente e não um comitê executor do Parlamento, que guarda sua autonomia em razão da separação das funções do Estado. Constrói-se a execução orçamentária, deste modo, como uma prerrogativa do governo contra o parlamento. Já se chegou a defender

\footnotetext{
${ }^{69}$ Cf. HECKEL, J. Die Legitimation des Grundgesetzes durch das deutsche Volk. In: ISENSEE, J.; KIRCHHOF, P. (ed.). Handbuch des Staatsrechts. $2^{\mathrm{a}}$ ed. Heidelberg: C. F. Müller Verlag, 1999. v. 2, p. 405; HETTLAGE, K. Die Finanzverfassung im Rahmen der Staatsverfassung. Veröffentlichung der Vereinigung der Deutschen Staatsrechtslehrer, Berlin, n. 14, 1956, p. 13.

${ }^{70}$ GÖTZ, V. Recht der Wirtschaftssubventionen. München: Beck, 1966, p. 298; HIRSCH, J.; SCHRÖDER, A.; ELLWEIN, T.; GÖRLITZ, A. Haushaltsplanung und Haushaltskontrolle in der Bundesrepublik Deutschland. Stuttgart-Berlin-Köln-Mainz: Kohlhammer, 1968, p. 45, 120, 126, 128.

71 HIRSCH, J.; SCHRÖDER, A.; ELLWEIN, T.; GÖRLITZ, A. Haushaltsplanung und Haushaltskontrolle in der Bundesrepublik Deutschland. Stuttgart-Berlin-Köln-Mainz: Kohlhammer, 1968, p. 36, 176.

${ }^{72}$ HOFFMAN, Reinhard. Haushaltsvollzug und Parlament. Tübingen: J. C. B. Mohr (Paul Siebeck), 1972, p. 14-5, 31 .
} 
que a interferência parlamentar nesta área "significaria fortalecer a natural propensão da democracia ao suicídio"

\subsection{Condições históricas do surgimento do direito orçamentário}

Em vista do antecedente, é necessário perquirir com mais atenção a mudança de paradigma sob esse aspecto da divisão de competências constitucionais no ciclo orçamentário. Para isto, devem-se observar os fundamentos históricos da teoria do orçamento como lei formal, em conexão com diversos aspectos político-constitucionais.

O direito orçamentário moderno se desenvolveu em função da disputa entre o monarca e a representação popular na Prússia da primeira metade do século XIX. Não é possível perder de perspectiva, deste modo, que a distribuição de competências orçamentárias se alinha com a Constituição concreta de determinado tempo e lugar. Somente é possível analisar tais competências de acordo com as características específicas da cada Constituição e da forma como se estabelecem as relações entre governo e parlamento em cada estrutura constitucional. Como expõe Hoffman ${ }^{74}$,

uma perspectiva a-histórica que abstraia e generalize situações
constitucionais concretas inevitavelmente conduzirá a uma
compreensão falsa da ordem de importância e da distribuição de
competências entre Parlamento e Governo também no direito
orçamentário.

O direito orçamentário sustentado até o momento presente muitas vezes corresponde às relações de poder entre o governo monárquico e o Parlamento ao tempo dos conflitos orçamentários e constitucionais da Prússia, quando Laband converteu o resultado político deste conflito em forma jurídica e o legitimou perante a Constituição. Depois que se obteve sucesso em evitar a ampliação dos poderes do Parlamento sobre um governo dependente do monarca, o governo reconheceu competências parlamentares sobre o orçamento, sob a condição politicamente imposta de que tais competências não

\footnotetext{
73 HETTLAGE, K. Die Finanzverfassung im Rahmen der Staatsverfassung. In Veröffentlichung der Vereinigung der Deutschen Staatsrechtslehrer, Berlin, n. 14, 1956, p. 11 e ss.

${ }^{74 ، " E i n e ~ u n h i s t o r i s c h e ~ v o n ~ d e r ~ k o n k r e t e n ~ V e r f a s s u n g s l a g e ~ a b s t r a h i e r e n d e, ~ v e r a l l g e m e i n e r n d e ~}$ Betrachtungsweise wird zwangsläufig zu einer falschen Gewichtung und Kompetenzverteilung zwischen Parlament und Regierung auch im Haushaltsrecht führen." (HOFFMAN, Reinhard. Haushaltsvollzug und Parlament. Tübingen: J. C. B. Mohr (Paul Siebeck), 1972, p. 18).
} 
pudessem ser usadas. ${ }^{75}$ A derrota das tentativas de emancipação da burguesia alemã do domínio estatal, que conduziu a uma composição desta burguesia com o princípio monárquico, é o momento de nascimento e a condição determinante do aparecimento do direito orçamentário no constitucionalismo tardio alemão ${ }^{76}$.

Desde o início do século XIX, a luta pelas prerrogativas orçamentárias do Parlamento foi uma parte importante da luta entre o Executivo do princípio monárquico, tardiamente absolutista, e as forças democráticas, sobretudo a burguesia, pelo controle do Estado. O ponto de partida foi a prerrogativa de consentir com a cobrança tributária. À medida que este poder procurou se estender também ao emprego dos recursos arrecadados e à determinação de limites à carga tributária, a influência do Parlamento sobre a atividade financeira do Estado representou também a disputa por poderes orçamentários mais amplos. A consequente decisão de que o orçamento deveria ser estabelecido sob a forma de lei não assumiu maiores significados jurídicos, como demonstrou Friauf, porque até então não se havia desenvolvido uma noção clara e conceitualmente determinada de lei. Antes, a "lei" se deixou surgir muito mais como a forma de ação conjunta do monarca e do parlamento, sem maiores diferenciações ${ }^{77}$. A disputa se conduziu principalmente quanto à vinculação do Executivo monárquico ao orçamento decidido no Parlamento num sentido negativo, isto é, quanto à proibição de que o governo gastasse sem autorização orçamentária. $O$ aspecto positivo desta vinculação, a significar que o Executivo deveria empregar os recursos exclusivamente na forma como dispôs o orçamento, cujos montantes seriam de execução obrigatória, não gerou disputas mais sérias ${ }^{78}$.

Este aspecto tem uma relevante implicação: o Parlamento se interessava predominantemente em determinar a economia de recursos por parte do governo, o que desaconselhava uma estrita vinculação do Executivo às dotações orçamentárias na fase de execução. A orientação fundamental das competências parlamentares sobre o

\footnotetext{
75 HECKEL, J. Die Legitimation des Grundgesetzes durch das deutsche Volk. In: ISENSEE, J.; KIRCHHOF, P. (ed.). Handbuch des Staatsrechts. $2^{\mathrm{a}}$ ed. Heidelberg: C. F. Müller Verlag, 1999, v. 2, p. 368; FRIAUF, K. Der Staatshaushaltsplan im Spannungsfeld zwischen Parlament und Regierung. Bad Homburg - Berlin - Zürich: Gehlen, 1968. v. 1, p. 13.

${ }^{76}$ HOFFMAN, Reinhard. Haushaltsvollzug und Parlament. Tübingen: J. C. B. Mohr (Paul Siebeck), 1972, p. 18-9.

77 FRIAUF, K. Der Staatshaushaltsplan im Spannungsfeld zwischen Parlament und Regierung. Bad Homburg - Berlin - Zürich: Gehlen, 1968. v. 1, p. 86 e ss.

${ }^{78}$ FRIAUF, K. Der Staatshaushaltsplan im Spannungsfeld zwischen Parlament und Regierung. Bad Homburg - Berlin - Zürich: Gehlen, 1968. v. 1, p. 130, 163 e ss.
} 
orçamento consistia em que o Poder Legislativo funcionasse como "o guardião natural de uma boa ordem financeira contra um governo perdulário",79. Isto é, o Parlamento era, sobretudo, o representante dos interesses dos pagadores de impostos contra o aumento da carga tributária. Esta função assecuratória configurava elemento essencial das funções do Parlamento: proteger a liberdade e a propriedade contra os ataques de um Executivo monárquico-feudal, ao passo que os efeitos positivos das competências orçamentárias em relação à atividade administrativa sempre foram vistos como uma consequência colateral que nunca esteve em primeiro plano.

Como pano de fundo desta perspectiva, preocupada com a função de controle financeiro do Executivo, desencadearam-se os conflitos orçamentários da década de 1860, de implicações tanto políticas como jurídicas. De acordo com Laband, o orçamento (e sua aprovação pelo Parlamento) não era algo necessário por princípios políticos ou constitucionais, mas exclusivamente por razões financeiras: a aprovação do orçamento pelo Parlamento não atendia a uma necessidade jurídica, mas econômica ${ }^{80}$. De forma correspondente, o orçamento pertenceria ao âmbito material das funções desempenhadas pelo Poder Executivo, e, conquanto sua votação pelo Legislativo indicasse uma repartição com o Parlamento da função administrativa desempenhada pelo Poder Executivo, este, a seu turno, não ficava limitado à execução da lei, mas contava com um campo irrestrito de livre atuação. Apesar do acordo entre o monarca e o Parlamento na aprovação do orçamento, este se conservava, materialmente, um ato administrativo, porque não enseja obrigações jurídicas, mas apenas prevê os resultados financeiros da Administração. O objetivo da participação do Parlamento na votação do orçamento foi reduzido por Laband à “obtenção do acordo entre Governo e Parlamento quanto ao teto das despesas necessárias e úteis" $"$.

De um ponto de vista dogmático-constitucional, decisiva para esta concepção se tornou a criação de um conceito dual de lei, e desta maneira a fissura do conceito constitucional costumeiro da lei em leis de sentido formal e outras de sentido material.

\footnotetext{
${ }^{79}$ HOFFMAN, Reinhard. Haushaltsvollzug und Parlament. Tübingen: J. C. B. Mohr (Paul Siebeck), 1972, p. 14-5, p. 20

${ }^{80}$ LABAND, Paul. Das Budgetrecht: Nach den Bestimmungen der Preussischen Verfassungs-Urkunde unter Berücksichtigung der Verfassung des Norddeutschen Bundes. Berlin: Verlag von J. Guttentag, 1871, p. 5.

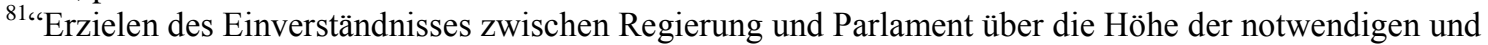
nützlichen Ausgaben.” (LABAND, Paul. Das Budgetrecht: Nach den Bestimmungen der Preussischen Verfassungs-Urkunde unter Berücksichtigung der Verfassung des Norddeutschen Bundes. Berlin: Verlag von J. Guttentag, 1871, p. 5).
} 
A lei formal se caracteriza tão já pela concretização da concordância entre monarca e parlamento. Uma lei em sentido material, ao contrário, apenas pode ser assim caracterizada se veicula um comando jurídico, isto é, se interfere na esfera jurídica de particulares ou do Estado. Atos que seguem o processo legislativo, mas que não têm conteúdo de lei, seriam leis apenas em sentido formal. Este conceito dualista tem para Laband a função de resolver o problema das competências entre Parlamento e Governo na monarquia constitucional. Disso resulta que o conceito de leis materiais se relaciona com a situação político-jurídica concreta e com a relação de tensão existente, em cada momento, entre Estado e Sociedade ${ }^{82}$.

De fato, a postulação de restrições ao alcance da lei se dirigia a combater a onipotência do Estado monárquico, de maneira que se protegesse a liberdade e a propriedade de interferências unilateralmente decididas pelo Estado. Sua função é, primariamente, negativa, sem que, de início, se vislumbrasse a conformação de obrigações positivas à ação administrativa. Tais restrições incluídas no conceito de lei em sentido material, igualmente, capturavam o âmbito externo das relações entre Estado e cidadãos, assim como das relações de cidadãos entre si. No âmbito interno, as normas que regulam relações do interior do próprio Estado não se submetiam aos limites impostos à lei, ao processo legislativo ou aos comandos jurídicos, e, desta forma, não se submetiam à decisão parlamentar, vistas que eram como prerrogativas monárquicas, passíveis de introdução unilateral no sistema jurídico. Não veiculavam comandos jurídicos e, desta forma, não ficavam compreendidas nas competências legislativas do Parlamento. Nesta categoria de atos foi que Laband situou o orçamento. ${ }^{83}$

A opinião de Laband pode ter atingido condições de se firmar como pensamento dominante a partir da realidade política e social de seu tempo, mas não se poderia dizer que, mesmo em seu início, tenha sido uma unanimidade. Hänel tornou-se seu principal opositor, recusando o conceito dual de lei e as consequências daí advindas para o orçamento público. Filiando-se ao conceito usual de lei, que compreenderia todo ato

\footnotetext{
${ }^{82}$ HOFFMAN, Reinhard. Haushaltsvollzug und Parlament. Tübingen: J. C. B. Mohr (Paul Siebeck), 1972 , p. 22.

${ }^{83}$ Cf. JESCH, D. Gesetz und Verwaltung. $2^{\text {a }}$ ed. Tübingen: Mohr Siebeck, 1968, p. 24.
} 
estatal advindo da expressão conjunta do consentimento do monarca e do parlamento seguindo o processo legislativo formal, independente de seu conteúdo, disse $\mathrm{Hänel}^{84}$ :

A lei constitucional, a lei juridicamente relevante tem um conteúdo necessário. Este é (...) toda aquela forma de manifestação da vontade estatal que é necessária e adequada à geração, com exclusividade, de direitos objetivos e à criação de comandos jurídicos.

Esta tese de que toda lei decidida pelo parlamento e pelo monarca possui conteúdo materialmente jurídico, sustenta-a Hänel concretamente com o exemplo do orçamento. As dotações orçamentárias podem produzir tanto autorizações como deveres jurídicos para a Administração, que só pode ser conduzida em conformidade com o orçamento público. A Administração ficaria obrigada a concretizar as receitas e despesas previstas, contudo, apenas na medida necessária para realizar os objetivos de cada dotação, conforme o documento aprovado. Daí se extrai que, conforme a intenção ${ }^{85}$ de cada dotação orçamentária, algumas delas podem conter efetivamente apenas uma autorização para atingir determinadas condições que permitam a efetivação de um objetivo, sem um dever estrito de sua execução pelo governo. Casos como este não constituem uma autorização apesar dos efeitos jurídicos vinculantes do orçamento, mas em decorrência da própria lei de orçamento, à medida que isto seja o previsto como necessário para satisfazer os objetivos das dotações orçamentárias. Enquanto do lado das receitas a maioria das disposições, segundo Hänel, acarreta o dever de sua execução pelo governo, sem discricionariedade quanto a arrecadar ou não ${ }^{86}$, do lado das despesas a maior parte das dotações não leva a um dever estrito de emprego dos recursos, mas apenas conduz à autorização do gasto para atingir determinado objetivo - mas disso não se permite extrair o princípio fundamental de que todas as previsões de despesa constituem, sempre e em todo caso, apenas uma autorização para gastar. Isto pode variar de caso para caso. Todavia, com relação àquelas despesas que não foram criadas por outras leis, o orçamento estabeleceria fundamento jurídico suficiente para a execução

\footnotetext{
84 "Das konstitutionelle, das rechtlich-relevante Gesetz hat einen notwendigen Inhalt. Es ist (...) diejenige Form des Staatswillens, welche ausschließlich für die Erzeugung von objektiven Rechte, für die Schaffung von Rechtssätzen bestimmt und geeignet ist." (HÄNEL, A. Studien zum Deutschen Staatsrechte. Leipzig: Hässel, 1873. v. 2, p. 275).

${ }^{85}$ Evita-se, aqui, falar em programa ou plano no sentido em que as expressões são usadas atualmente. Patente, porém, é a aproximação das ideias de Hänel com outras que viriam a ser desenvolvidas apenas no século XX, com o desenvolvimento das ideias de planejamento da ação governamental.

${ }^{86}$ Já se superou, na ordem constitucional vigente no Brasil, bem como em diversas outras, o princípio da anualidade tributária, segundo o qual a previsão da receita tributária no orçamento anual é condição de sua arrecadação.
} 
nos montantes previstos, pois a finalidade da despesa é nele encontrada, e não em outra lei que criou a necessidade da despesa. A aprovação do orçamento como uma consolidação de todas as receitas e despesas previstas para o exercício se situa além de uma autorização ao Executivo e pode ocorrer apenas na forma da lei, o que, necessariamente, atribui ao orçamento caráter jurídico material. Segundo esta opinião, que toma em conta certamente um outro conceito de lei, no mais também defendida por Rönne e Zorn, a falha da teoria labandiana está neste ponto, ao implicar que determinados comandos jurídicos possam ser explicados como não-comandos jurídicos ${ }^{87}$.

Do ponto de vista de Hänel, assim, se poderia assumir, como faz Hoffman, que dotações específicas, especialmente aquelas que preveem despesas, não somente representariam uma autorização, mas obrigariam o governo à execução, caso assim previsse a lei orçamentária. Esta posição, contudo, não atingiu grande significado no momento em que foi formulada, pela maior preocupação dos parlamentos com a contenção, e não com o emprego, de recursos públicos ${ }^{88}$.

Embora não se possa deixar de querer atribuir alguma forma de justiça histórica à opinião minoritária de Hänel, tal julgamento poderia se mostrar estéril em razão de sua abstração. A situação política e social concreta em que se deram as condições históricas de desenvolvimento da teoria labandiana, que se relaciona com a derrota do movimento burguês liberal e com a vitória do princípio monárquico na Alemanha, precisa ser levada em conta. Talvez por essa razão a teoria do orçamento como lei formal tenha sido ampla e acriticamente assumida pela República de Weimar ${ }^{89}$, quando uma mudança constitucional significativa, surpreendentemente ou não, não se fez

\footnotetext{
${ }^{87}$ HÄNEL, A. Studien zum Deutschen Staatsrechte. Leipzig: Hässel, 1873, v. 2, p. 275, 320 e ss., 326, 354; RÖNNE, L. Das Staatsrecht der Preussischen Monarchie. $4^{a}$ ed. Leipzig, 1884. v. 4, p. 743; ZORN, P. Das Staatsrecht des Deutschen Reiches. $2^{\mathrm{a}}$ ed. Berlin-Leipzig: Guttentag, 1895. v. 1, p. 449.

${ }^{88}$ HOFFMAN, Reinhard. Haushaltsvollzug und Parlament. Tübingen: J. C. B. Mohr (Paul Siebeck), 1972, p. 25.

${ }^{89}$ Registre-se que, mesmo durante a República de Weimar, a questão da vinculação do governo ao orçamento na fase de execução não foi tema pacífico. Observando as novas influências que a Constituição autorizada ao Parlamento exercer sobre o Governo, Bilfinger contribuiu para lançar a questão fundamental de estar ou não o governo constitucionalmente obrigado a executar lealmente os programas previstos no orçamento. Durante a efêmera República de Weimar, porém, a questão não pode ser aprofundada. Cf. BILFINGER, C. Der Streit um das Panzerschiff A und die Reichsverfassung. Archiv des öffentlichen Rechts (Ä̈R), Tübingen, 55, 1929, p. 416 e ss.
} 
acompanhar de uma simétrica mudança da disciplina jurídica do orçamento público que vinha do período anterior. ${ }^{90}$

Contudo, para evitar o perigo de incorrer na prática aqui criticada, que seria repetir e aplicar teorias e doutrinas deslocadas de seus respectivos contextos, não é possível parar no que se desenvolveu no século XIX. A par de mudanças políticas e constitucionais significativas, o orçamento não tem mais as mesmas funções que tinha há duas centúrias.

\subsubsection{As transformações das funções do orçamento}

O que foi aqui esquematizado deve ser ainda acrescido de considerações de outra ordem: o orçamento público passou por significativas alterações de suas funções desde o século XIX, o que propõe nova sorte de considerações sobre sua natureza.

\subsubsection{A superação do paradigma do controle}

A ideia de que o orçamento é um ato de condução do Estado, ou "um plano político quantitativamente mensurável"91, fixa uma relação imediata com determinado programa de governo à medida que, a partir de um consenso político, se estabelecem os objetivos prioritários da atuação estatal. As decisões orçamentárias são, assim, a expressão financeira das tarefas estatais decididas politicamente ${ }^{92}$. Ele expressa, por assim dizer, o consenso possível de alcançar sobre quais são as necessidades públicas, indicando o que os cidadãos receberão como membros daquela comunidade. Expressa, também, o tamanho do Estado: o governo deve prover serviços que o setor privado pode fornecer? O orçamento ainda dá concretude a noções ora muito vagas de justiça fiscal, definindo qual a extensão de programas tais como a construção de casas populares, escolhendo indivíduos de acordo com suas necessidades e possibilidades.

\footnotetext{
90 HOFFMAN, Reinhard. Haushaltsvollzug und Parlament. Tübingen: J. C. B. Mohr (Paul Siebeck), 1972, p. 26.

${ }^{91}$ NEUMARK, Fritz. Theorie und Praxis des Budgetgestaltung. In: GERLOFF, Wilhelm; NEUMARK, Fritz. Handbuch der Finanzwissenschaft. $2^{a}$ ed. Tübingen: J. C. B. Mohr, 1952. v. 1, p. 554.

${ }^{92}$ HOFFMAN, Reinhard. Haushaltsvollzug und Parlament. Tübingen: J. C. B. Mohr (Paul Siebeck), 1972, p. 14-5, 35 .
} 
As escolhas refletem prioridades, com diversas implicações. Ideológicas, destinando mais recursos a programas sociais ou à segurança pública. Federativas, com maior transferência de recursos para as regiões mais pobres do que às mais prósperas. Político-eleitorais, determinando quais grupos ficam com quanto, por meio da mediação de interesses conflitantes. Os orçamentos invariavelmente refletem o grau de importância que o legislador orçamentário dá à satisfação de seus eleitores, na região eleitoral que mais lhe convenha.

Ainda, o orçamento é uma poderosa ferramenta de controle político. Apesar de razoável complexidade técnica, é instrumento à disposição do cidadão que quer saber como o governo gasta seu dinheiro e se tem atendido a suas preferências. As diversas teorias da escolha pública e da representação política reforçam o orçamento como meio de fazer a relação entre a preferência do eleitor e a decisão governamental, sendo, portanto, um meio bastante relevante de implementar a democracia. Este aspecto indica, também, a possibilidade de verificar mais concretamente o tamanho e o peso relativo da carga tributária em cada grupo de contribuintes.

O orçamento, por fim e para além da retórica do discurso político, permite saber qual é o efetivo peso de determinados indivíduos e organizações na determinação da escolha pública. O processo da decisão orçamentária ilustra a importância que têm os diversos órgãos governamentais na decisão financeira, assim como o significado relativo dos indivíduos em comparação com grupos de interesses.

Por tudo isso, mas não só, o orçamento público é político. Como formulou o presidente Roosevelt em 1942, o orçamento é “nosso programa nacional. É uma antecipação do nosso plano de trabalho, uma previsão das coisas que virão. Ele traça o curso da nação." 93 A opção por um orçamento cuja função seja restringir os gastos governamentais é, deste modo, também uma escolha política. $\mathrm{Na}$ origem do direito orçamentário moderno, se vislumbrava no Parlamento o já mencionado papel de protetor de uma boa ordem financeira. Isto significa: o papel de freio aos impulsos gastadores do governo, que inevitavelmente acarretariam o aumento dos efeitos da carga tributária sobre o patrimônio do contribuinte, com implicações sobre a atividade

\footnotetext{
${ }^{93}$ ROOSEVELT apud HEINIG, K. Das Budget. Tübingen: J. C. B. Mohr (Paul Siebeck), 1949. v. 1, p. 5. No original: "(...) our national program. It's a preview of our work plan, a forecast of things to come. It charts the course of the nation".
} 
econômica. A aprovação, pelo Parlamento, dos orçamentos elaborados pelo Executivo aparece como a construção jurídico-institucional de uma maneira de assegurar aquele objetivo político.

Sem que isto implique uma negação completa deste objetivo, acontece que, no presente, as relações políticas entre Executivo e Legislativo exibidas no orçamento público sofreram um deslocamento importante de ser notado. Grande ênfase era dada à fase de aprovação do orçamento como uma prerrogativa do Parlamento contra o ímpeto perdulário do governo. Presentemente se colocam à disposição do Executivo diversos instrumentos de flexibilidade para que este seja o poder que, na fase de execução, tenha condições de corrigir os excessos de um Legislativo inclinado a gastos irresponsáveis. Houve uma mudança na concepção política sobre quem é o guardião de uma política responsável. Costuma-se entender que cabe, portanto, ao Executivo o papel de implementar políticas fiscais impopulares, e isto se realiza principalmente na fase de execução, em que o orçamento antecipadamente elaborado encontra-se confrontado com a realidade econômica. Neste sentido, o orçamento público é hoje um fenômeno marcadamente econômico capaz de colocar diversas questões político-econômicas e também sociais, e dificilmente se pode hoje afirmar sua neutralidade. ${ }^{94} \mathrm{E}$ sendo o Parlamento órgão com amplas prerrogativas políticas, não se pode afirmar que atualmente suas competências orçamentárias se destinem exclusivamente a evitar o aumento da carga tributária.

A ênfase dada a esta função política dos orçamentos públicos não deve, porém, ser exagerada. Certamente o orçamento é o resultado de longas e numerosas discussões nos órgãos administrativas, assim como de negociações entre governo e parlamento. É a expressão de um consenso. As vinculações de receitas e despesas obrigatórias consomem, porém, grande parte do orçamento federal brasileiro, estimando-se que o volume das despesas obrigatórias de caráter continuado atinja $90 \%$ dos gastos primários do governo federal. ${ }^{95}$ A margem de manobra da decisão política é limitada.

\footnotetext{
94 HOFFMAN, Reinhard. Haushaltsvollzug und Parlament. Tübingen: J. C. B. Mohr (Paul Siebeck), 1972 , p. 36.

${ }^{95}$ SANTA HELENA, E.; GREGGIANIN, E.; PEREIRA FILHO, L.; SANTOS, M.; BATISTA Jr., S.; GONTIJO, V. Orçamento Impositivo e Despesas Obrigatórias Continuadas: introdução do orçamento impositivo no ordenamento brasileiro e crescimento das despesas obrigatórias continuadas. Brasília: Câmara dos Deputados, 2010, p. 2.
} 
Além disso, este programa de governo expresso no orçamento operaria no vácuo se não atentasse às condições de sua realização e não se preocupasse com a manutenção do equilíbrio econômico. Como consequência, o orçamento desempenha também uma função político-financeira ${ }^{96}$, à medida que tem que ajustar a realização de um programa com o ambiente e as circunstâncias em que opera. É desta maneira que, concomitantemente, o orçamento público se torna o meio de realizar políticas econômicas, políticas estruturais e políticas conjunturais. ${ }^{97}$

Finalmente, pode-se observar no orçamento também uma função jurídica, na medida em que expõe, em lei, os limites financeiros da atividade administrativa e em que as modificações destes limites sem autorização legal podem desencadear a aplicação de sanções $^{98}$. O orçamento é, deste modo, fundamento do controle da Administração ${ }^{99}$. Outra expressão deste controle é o princípio da unidade orçamentária: contendo a totalidade das receitas e despesas públicas, o orçamento é um documento capaz de demonstrar se a execução dos montantes financeiros ali expostos é crível.

Importante, também, é que a lei de orçamento permite ao Parlamento, e principalmente à oposição, o controle político de seu cumprimento (controle políticoparlamentar ${ }^{100}$ ). Tem a função de permitir, deste modo, que a oposição tenha a possibilidade de realizar uma discussão política geral sobre a condução orçamentária e a política econômica do governo.

Chegando a este ponto, que no mais já fora mencionado, a comparação destas funções expõe uma profunda alteração ocorrida no orçamento público desde o Estado Liberal do século XIX. A função de controle e, deste modo, a função jurídica do orçamento, era a mais importante - o que se cristalizou no debate sobre sua natureza

\footnotetext{
96 KRÜGER-SPITTA, Wolfgang; BRONK, Horst. Einführung in das Haushaltsrecht und die Haushaltspolitik. Darmstadt: Wissenschaftliche Buchgesellschaft, 1973, p. 29.

97 KRÜGER-SPITTA, Wolfgang; BRONK, Horst. Einführung in das Haushaltsrecht und die Haushaltspolitik. Darmstadt: Wissenschaftliche Buchgesellschaft, 1973, p. 30.

${ }^{98}$ MANDELARTZ, H. Das Zusammenwirken von Parlament und Regierung beim Haushaltsvollzug: ein Beitrag zur parlamentarischen Regierungssystem der Bundesrepublik Deutschland. Frankfurt a.M.: Peter D. Lang, 1980, p. 70.

${ }^{99}$ Em sentido contrário, cf. SENF, P. Budget. In: Handwörterbuch der Sozialwissenschaften. Stuttgart: Fischer, 1959. v. 2, p. 430. O autor diferencia a função de controle da função jurídica. Parece adequado, porém, considerar esta função de controle como parte de uma função jurídica geral do orçamento, resultante de seu caráter legal (RÜRUP, B. Die Programmfunktion des Bundeshaushaltsplanes. Berlin: Duncker \& Humblot, 1971, p. 17).

${ }^{100}$ MANDELARTZ, H. Das Zusammenwirken von Parlament und Regierung beim Haushaltsvollzug: ein Beitrag zur parlamentarischen Regierungssystem der Bundesrepublik Deutschland. Frankfurt a.M.: Peter D. Lang, 1980, p. 70.
} 
jurídica. A função de determinar as políticas a serem desempenhadas em determinado espaço de tempo foi subestimada. ${ }^{101}$ É compreensível, assim, que o Parlamento tenha sido visto como um freio ao aumento de despesas. Sua principal função era mantê-las tão baixas quanto possível. A tendência de que o Parlamento passasse a ser visto como favorável ao aumento das despesas, a partir do surgimento de uma democracia de partidos ${ }^{102}$, ao lado do crescimento geral das despesas públicas, fez com que esta ideia se alterasse. Como, porém, o aumento da arrecadação apresenta suas dificuldades técnicas, políticas e econômicas, coloca-se o problema de objetivos e despesas, de um lado, e recursos financeiros limitados, de outro. $\mathrm{O}$ orçamento representa, deste modo, uma escolha entre objetivos que serão cumpridos no próximo exercício financeiro e outros que não serão. Esta escolha não poderia ser tomada abstratamente, num procedimento exclusivamente lógico, porque depende, necessariamente, de juízos de valor sobre as necessidades públicas ${ }^{103}$. Esta função política é tanto mais importante quanto maior é a margem de manobra da decisão orçamentária ${ }^{104}$.

Assim, aquela função político-financeira anteriormente citada, que se caracteriza pela necessidade de ajustar o orçamento à conjuntura, pressupõe uma prévia definição dos objetivos políticos gerais. Não se sobrepõe, mas se subordina a tais objetivos, que o orçamento faz conhecer. Sem relação a eles, ela é vazia de conteúdo ${ }^{105}$. Da mesma maneira, se relaciona com a função jurídica, que não tem por única preocupação o equilíbrio numérico entre receitas e despesas, mas, também, o controle sobre a realização dos objetivos e a concretização dos resultados pretendidos. A mudança de funções do próprio Estado teve por efeito a predominância da função política de

\footnotetext{
${ }^{101}$ Cf. FRIAUF, K. Der Staatshaushaltsplan im Spannungsfeld zwischen Parlament und Regierung. Bad Homburg - Berlin - Zürich: Gehlen, 1968. v. 1, p. 177 e ss.

${ }^{102}$ HOFFMAN, Reinhard. Haushaltsvollzug und Parlament. Tübingen: J. C. B. Mohr (Paul Siebeck), 1972 , p. 35

103 FRIAUF, K. Der Staatshaushaltsplan im Spannungsfeld zwischen Parlament und Regierung. Bad Homburg - Berlin - Zürich: Gehlen, 1968. v. 1, p. 218.

${ }^{104}$ Engloba-se na ideia de função política também a consecução de objetivos sociais e econômicos por meio do orçamento. A ideia do orçamento como exibição de programas, portanto, fica compreendida na sua função política. Cf. MANDELARTZ, H. Das Zusammenwirken von Parlament und Regierung beim Haushaltsvollzug: ein Beitrag zur parlamentarischen Regierungssystem der Bundesrepublik Deutschland. Frankfurt a.M.: Peter D. Lang, 1980, p. 73.

${ }^{105}$ RÜRUP, B. Die Programmfunktion des Bundeshaushaltsplanes. Berlin: Duncker \& Humblot, 1971, p. 18.
} 
planejamento desempenhada pelo orçamento ${ }^{106}$, o qual, atualmente, mesmo em sistemas mais liberais, sempre exprime um plano para o setor público ${ }^{107}$.

Com o advento da Lei de Responsabilidade Fiscal (LC 101/2000), porém, esta função político-financeira ganhou maior autonomia. Ao disciplinar a limitação de empenho e movimentação financeira (art. $9^{\circ}$ ), este diploma estabeleceu que, independentemente dos objetivos contidos no orçamento, deve-se proceder ao contingenciamento de recursos se a arrecadação não comportar o cumprimento de metas previstas no Anexo de Metas Fiscais. Tudo isto segundo critérios estabelecidos pela Lei de Diretrizes Orçamentárias, que pode definir gastos não-contingenciáveis. Ocorre que, mesmo neste caso que vem a apontar um caráter autorizador do orçamento, não se tem uma permissão geral para não gastar. O que ali se prevê é uma condição específica para a diminuição no ritmo do gasto: o influxo insuficiente de recursos. Fora deste contexto de incompatibilidade da arrecadação com o Anexo de Metas Fiscais, portanto, continua a prevalecer a subordinação da função político-financeira a uma função política geral de cumprimento dos objetivos programados pelo orçamento.

Assim, sendo um instrumento aberto à conjuntura, destinado a atuar sobre ela, é preciso que se adotem técnicas adequadas para tanto. Tais técnicas concretizam o que modernamente se pode denominar de planejamento orçamentário. O orçamento é, atualmente, um instrumento político de planejamento em diversos aspectos, utilizável para atingir diversas finalidades. As relações entre orçamento e planejamento merecem, então, maior exploração, por sua direta relevância à execução orçamentária.

\subsubsection{Orçamento e planejamento}

O aperfeiçoamento das técnicas orçamentárias conduziu a uma maior associação entre orçamento e planejamento, embora este não necessariamente se reduza àquele. São diversas as técnicas, pois, que servem ao planejamento aqui tratado. A partir de meados do século XX, a pressão para gastar mais eficientemente provocou uma aceitação quase universal de que, sendo necessário o planejamento, o processo

\footnotetext{
${ }^{106}$ MANDELARTZ, H. Das Zusammenwirken von Parlament und Regierung beim Haushaltsvollzug: ein Beitrag zur parlamentarischen Regierungssystem der Bundesrepublik Deutschland. Frankfurt a.M.: Peter D. Lang, 1980, p. 73.

${ }^{107}$ JARACH, Dino. Finanzas Publicas y Derecho Tributario. Buenos Aires: ed. Cangallo, 1985, p. 79-80.
} 
orçamentário não consiste apenas em planejar para obter maiores entradas de recursos, mas também, e até primariamente, planejar para atingir resultados desejados. A tônica é a obtenção de resultados e sua avaliação. ${ }^{108}$

O planejamento é recebido como verdadeiro princípio, que atinge não somente o tratamento constitucional do orçamento público, mas diversos outros subsistemas da Constituição. ${ }^{109}$

A técnica do orçamento-programa desempenhou um importante papel nesse desenvolvimento. Embora o orçamento por programas apareça nos Estados Unidos já após a II Guerra Mundial, o termo está associado a reformas empreendidas neste país na década de 50. Esta abordagem do orçamento público, que pretendia desenvolver informações sobre resultados obtidos pelo orçamento de modo a orientar o processo orçamentário, teve seu maior desenvolvimento com a Comissão Hoover, a qual recomendou que "todo o conceito orçamentário do governo federal deveria ser concebido a partir da adoção de um orçamento baseado em funções, atividades, e projetos; é isto o que designamos orçamento de desempenho". ${ }^{110}$ Nota-se que orçamento-programa e orçamento por performance são, aí, usados quase como sinônimos.

As reformas então feitas não eram vistas como mudanças profundas no processo de decisão orçamentária, mas um ajuste que talvez fosse relevante. Esbarravam, porém, num sistema de contabilidade falho que era incapaz de identificar os custos totais das operações governamentais. Outra dificuldade era a mensuração do desempenho, e, apontando limites humanos, a falta de interesse das autoridades encarregadas de tomar decisões em usar os dados obtidos pela análise de performance. ${ }^{111}$

Não obstante, as tentativas persistiram e continuaram a ser adotadas pelos Estados Unidos, no plano federal. Em 1961, o Ministério da Defesa implementou um orçamento do tipo PPBS em seu âmbito. Esta técnica providencia a organização

\footnotetext{
${ }^{108}$ FÖLSCHER, Alta. Budget Methods and Practices. In SHAH, Anwar (coord.). Budgeting and Budgetary Institutions. Washington: The World Bank, 2007, p. 119.

${ }^{109}$ TORRES, Ricardo Lobo. Tratado de Direito Constitucional Financeiro e Tributário. $3^{\mathrm{a}}$ ed. Rio de Janeiro: Renovar, 2008. v. 5, p. 78.

${ }^{110}$ Cf. DIAMOND, Jack. From Program to Performance Budgeting: the Challenge for Emerging Market Economies. Washington: International Monetary Fund (Working Paper), jun. 2003, p. 4. No original: "the whole budgetary concept of the federal government should be fashioned by the adoption of a budget based on functions, activities, and projects; this we designate a performance budget".

${ }^{111}$ Cf. BURKHEAD, Jesse. Government Budgeting. New York: John Wiley and Sons, 1956.
} 
orçamentária em, basicamente, três fases: a fase de planejamento (planning) se encarrega de identificar objetivos atuais ou futuros, assim como os meios de se atingilos; a fase de programação (programming) se ocupa de integrar as propostas feitas pelo planejamento em programas organizados numa hierarquia de prioridades, que serão objeto de uma decisão política em diferentes níveis hierárquicos; a terceira fase consiste na tradução de cada programa plurianual em ações específicas anuais, determinando quem faz o quê e, a partir disso, destinando-lhe um determinado volume de recursos. $\mathrm{O}$ sistema, porém, foi vítima de sua própria ambição e, a partir de 1971, abandonado nos Estados Unidos. Como explica Axelrod, a raiz destes problemas estava, muitas vezes, na falta de prepare dos servidores públicos para realizar os objetivos do plano. ${ }^{112}$ É um tipo de técnica que, segundo Wildavsky, caracterizava-se por uma vasta quantidade de informações inócuas e por uma prematura quantificação de itens irrelevantes ${ }^{113}$.

O orçamento base-zero padeceu de dificuldades semelhantes, partindo sempre de uma boa ideia inicial: trata-se de uma técnica que requer que todos os órgãos elaborem anualmente seus orçamentos como se tomassem decisões totalmente novas, isto é, como se o órgão encarregado de elaborar sua proposta começasse o ano com uma folha em branco. A cada ano estes órgãos requereriam determinada dotação, baseada numa análise do custo total de cada programa. Como, desta forma, a continuidade dos objetivos não é garantida, dificulta-se que aqueles que não sejam mais desejados sigam $\operatorname{adiante}^{114}$.

Tais sistemas, porém, sofrem do problema aventado por Herbert Simon: há limites cognitivos à habilidade dos tomadores de decisão ao considerar todas as opções disponíveis. Esses limites os forçam a considerar alternativas e possibilidades seletivamente, e, ainda assim, sempre com base em sua ideologia ou na circunstância política. ${ }^{115}$

No Brasil, a Lei 4.320/64 adotou a técnica do orçamento-programa, estabelecendo, em seu art. $2^{\circ}$, que a lei de orçamento conterá a discriminação da receita e despesa de forma a evidenciar a política econômico-financeira e o programa de

\footnotetext{
${ }^{112}$ AXELROD, D. Budgeting for Modern Government. New York: St. Martin's Press, 1988, p. 288.

113 WILDAVSKY, Aaron. Planning-Programing-Budgeting: Rescuing Policy Analysis from PPBS. Public Administration Review, Washington,D.C, v. 29, n. 2, 1969, p. 169-202.

114 FÖLSCHER, Alta. Budget Methods and Practices. In: SHAH, Anwar (coord.). Budgeting and Budgetary Institutions. Washington: The World Bank, 2007, p. 121.

115 FÖLSCHER, Alta. Budget Methods and Practices. In: SHAH, Anwar (coord.). Budgeting and Budgetary Institutions. Washington: The World Bank, 2007, p. 123.
} 
trabalho do Governo, obedecidos os princípios de unidade, universalidade e anualidade. Isto é, os mecanismos de organização financeira do Estado devem ser estruturados de modo a tornar claros os objetivos e permitir análise de resultados, razão pela qual ganha importância a forma como a classificação das despesas públicas será feita. Neste aspecto, a classificação funcional-programática adquire enorme relevância ${ }^{116}$.

As diretrizes constitucionais de 1988, a seu turno, tiveram o mérito de transformar o planejamento num processo contínuo da ação estatal, de modo a reduzir e controlar o grau de discricionariedade intrínseca a ela. Isto conduziu, porém, a outro extremo das relações entre plano e orçamento, incitando alguns diagnósticos de que um dos problemas mais relevantes deste sistema é que o planejamento teve seu horizonte reduzido a médio e curto prazos, condicionando-se ao orçamento disponível e, na verdade, transformando-se num instrumento de ações operacionais cotidianas do Estado, excessivamente centrado na gestão e menos nas estratégias ${ }^{117}$.

Os Planos Plurianuais (PPAs) tornaram-se o instrumento principal do planejamento no atual sistema financeiro constitucional, incorporados ao processo orçamentário regular, válidos para períodos de quatro anos, e que começaram a ser efetivamente estruturados na década de 1990. O planejamento da ação governamental por PPAs caracteriza-se por ser tanto um processo contínuo como, também, pouco disruptivo, pois o primeiro ano de gestão de determinado presidente tem sempre de executar o último ano de planejamento previsto no PPA do governo anterior. Caracteriza-se, igualmente, por permitir uma junção entre o orçamento do plano (recursos financeiros) e sua execução propriamente dita (metas físicas), o que é feito pelo detalhamento do plano geral em programas e ações setorialmente organizados e $\operatorname{coordenados}^{118}$. Sobre este último aspecto, a articulação entre o PPA e a Lei Orçamentária Anual (LOA) ganhou um instrumento importante, destinado a operacionalizar esta relação entre plano e orçamento: a Lei de Diretrizes Orçamentárias (LDO), que tem a finalidade de estabelecer diretrizes e metas para o próximo orçamento, de acordo com o que disponha previamente o PPA.

\footnotetext{
${ }^{116}$ CONTI, José Maurício. A Autonomia Financeira do Poder Judiciário. São Paulo: MP Editora, 2006, p. 69.

${ }_{117}$ CONTI, José Maurício. A Autonomia Financeira do Poder Judiciário. São Paulo: MP Editora, 2006, p. 20.

${ }^{118}$ CARDOSO Jr, José Celso. Planejamento Governamental e Gestão Pública no Brasil: elementos para ressignificar o debate e qualificar o Estado. Brasília: IPEA, 2011, p. 21-22.
} 
A justificação do planejamento, entendido aqui em seu sentido não meramente orçamentário, enfrenta, todavia, uma grande problemática, que é a sua relação, como instrumento de ação estatal, com cada um dos Poderes do Estado. ${ }^{119}$ Demonstrado que o orçamento se organiza de modo articulado a um plano, pela própria estrutura de um orçamento-programa, a divisão das fases do ciclo orçamentário entre os Poderes Executivo e Legislativo nem sempre pode ser mantida. Isto porque a execução do orçamento conforme seu planejamento lida com situações contingentes em que é necessário, por vezes, ultrapassar o volume de recursos previstos para as metas físicas do plano, ou reduzir outras. Tudo isto se passa na execução, tradicionalmente atribuída ao Poder Executivo. O que ocorre é que o processo previsto para tais modificações orçamentárias, em maior ou menor grau, depende da participação do Poder Legislativo, que poderia ser ampliada para aperfeiçoar seus instrumentos de controle e participação nesta etapa.

Cabendo a aprovação final do orçamento e demais leis orçamentárias ao Poder Legislativo, deve-se entender que tal sistemática não reduz o plano de governo a um plano do governo. O Parlamento decide a respeito, e suas prerrogativas de controle devem ser preservadas na ocasião de inevitáveis medidas de flexibilização do plano. Isto ficará evidente ao tratar dos instrumentos de flexibilidade orçamentária.

\subsubsection{Os limites da decisão de planejar}

A possibilidade de que o orçamento seja instrumento adequado para concretizar o planejamento e executar estratégicas esbarra, porém, numa dificuldade, representada pela hipótese bastante consistente de que o processo orçamentário tem por característica ser um sistema incremental. Poucos outros temas, na ciência política, marcaram tanto a literatura sobre o orçamento público como o do incrementalismo. O termo foi definido por Charles Lindblom ${ }^{120}$ e Aaron Wildavsky ${ }^{121}$, dentre outros, nos anos 1950 e 1960, e, nas décadas seguintes, uma série de estudos foi publicada para confirmar ou refutar, empiricamente, este tese. O termo, porém, tem muitos significados, não sendo utilizado

\footnotetext{
119 HOPPE, W. Planung. In: ISENSEE, J.; KIRCHHOF, P. (ed.). Handbuch des Staatsrechts. $3^{\mathrm{a}}$ ed. Heidelberg: C. F. Müller Verlag, 2004, p. 329.

${ }^{120}$ DAHL, R. A.; LINDBLOM, C. Politics, Economics and Welfare. New York: Harper and Row, 1953.

${ }^{121}$ WILDAVSKY, Aaron. The Politics of the Budgetary Process. Boston: Little Brown, 1964.
} 
de maneira uniforme. Em artigo bastante completo, William Berry aponta seu uso de 12 maneiras distintas ${ }^{122}$, que serão tratadas, brevemente, em alguns de seus aspectos principais.

As primeiras definições do incrementalismo, dadas pelo citado artigo de Lindblom, se dedicaram a explicar como as decisões orçamentárias ocorrem por meio de um incrementalismo desarticulado (disjointed incrementalism) e comparações sucessivas limitadas (successive limited comparisons). Estas várias características dão origem a alguns sentidos da expressão, destinados a explicar como o processo orçamentário é marcado pela simplificação do modo de decisão, de maneira a reduzir a complexidade e o número de informações. Assim, um processo orçamentário incrementativo é marcado pela redução a alternativas não inovadoras. Toda decisão se depara com um número muito elevado de possibilidades, incluindo aquelas altamente originais. O tomador de decisões, entretanto, para que possa lidar com a infindável quantidade de possibilidades, tende a considerar as políticas mais viáveis, isto é, aquelas que, em comparação com as políticas atuais, não guardem grandes diferenças ${ }^{123}$. Simplificação e racionalização do processo de decisão passam, assim, pela redução de alternativas possíveis.

Os tomadores de decisões orçamentárias, ainda, não agem de modo a considerar todas as possibilidades e escolher aquela que seja a mais viável para atingir os objetivos. Em vez disso, eles se "acomodam", avaliando as alternativas de maneira seqüencial e escolhendo aquela primeira que seja minimamente aceitável ${ }^{124}$. Isto também significa a desconsideração de uma análise exaustiva das consequiências de todas as decisões orçamentárias: a decisão incremental limita a análise de conseqüências à “margem”, isto é, ao modo pelo qual as consequiências se diferenciam daquelas apresentadas pelas políticas já atualmente feitas ${ }^{125}$. Ocorre, ainda, a "dependência dos fins aos meios": ao contrário de um processo no qual os objetivos são fixados antes das decisões orçamentárias, por um método incremental fins e meios são mutuamente dependentes,

\footnotetext{
${ }^{122}$ BERRY, W. The Confusing Case of Budgetary Incrementalism: too many meanings for a single concept. The Journal of Politics, v. 52, n. 1, fev. 1990, p. 167-196.

${ }^{123}$ LINDBLOM, C. The Science of Muddling Through. Public Administration Review, v. 19, 1959, p. 84.

${ }^{124}$ WILDAVSKY, Aaron. The Politics of the Budgetary Process. Boston: Little Brown, 1964, p. 12-3.

${ }^{125}$ BAYBROOKE, D.; LINDBLOM, C. A Strategy of Decisions: Policy Evaluation as a Social Process. New York: Free Press of Glencoe, 1963, p. 83-6.
} 
no sentido de que os fins são modificáveis e passíveis de revisão até que os meios se mostrem os mais adequados para satisfazê-los ${ }^{126}$.

Além destas definições, o incrementalismo pode ser entendido em um sentido mais geral, associando-se àqueles processos em que os agentes têm que tomar decisões simples, apesar da aparência de complexidade. Ao testarem modelos de incrementalismo, Cowart, Hansen e Bofoss introduzem a idéia de que

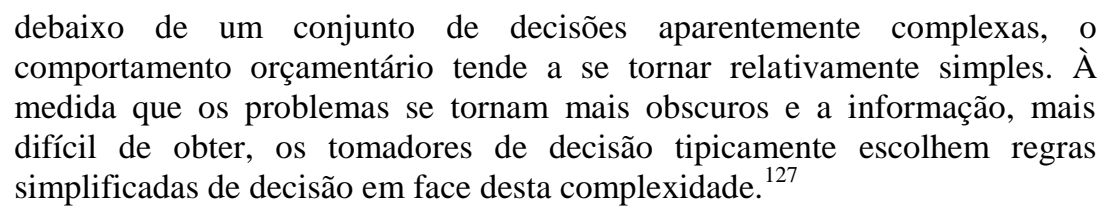

A decisão orçamentária se torna, desta maneira, padronizada ${ }^{128}$. Se de um lado, porém, os trabalhos de Lindblom se aplicam a processos de decisões complexas em geral, foi Wildavsky que começou a se dedicar, especificamente, ao incrementalismo no sistema orçamentário. Qualificou, então, o incrementalismo como um processo de “desatenção à base", entendendo-se a base como o patamar prévio das despesas. ${ }^{129}$ Esta é vista como um dado, um ponto prévio de partida, e as decisões tomadas não se destinam a revisá-la. Com isto, dedica-se atenção a um número menor de alternativas possíveis, que tendem a ser não inovadoras. A decisão destina-se tão-somente ao nível de incremento. Mas este incrementalismo não diminui a complexidade do processo orçamentário apenas por reduzir a quantidade de informação com a qual os agentes têm de lidar, mas também por, potencialmente, reduzir o conflito e as disputas políticas à medida que a "base" da qual parte o orçamento já está protegida ${ }^{130}$.

O incrementalismo ainda é o resultado das negociações entre os diferentes sujeitos da decisão orçamentária, cada qual com competências bastante reduzidas e delimitadas, o que fica bem expresso por Bozeman e Strauss, ao dizerem que uma de suas causas é a "compartimentalização dos papeis orçamentários, o que significa que a

\footnotetext{
${ }^{126}$ BAYBROOKE, D.; LINDBLOM, C. A Strategy of Decisions: Policy Evaluation as a Social Process. New York: Free Press of Glencoe, 1963, p. 83-6, p. 94.

127 COWART, A.; HANSEN, T.; BOFOSS, K. Budgetary Strategies and Sucess at Multiple Decision Levels in the Norwegian Urban Setting. American Political Science Review, v. 69, 1975, p. 543, tradução livre.

${ }^{128}$ KIEWIET, Roderick; McCUBBINS, Mathew. Appropriations Decisions as a Bilateral Bargaining Game between President and Congress. Legislative Studies Quarterly, v. 10, n. 2, mai. 1985, p. 181-201.

${ }^{129}$ WILDAVSKY, Aaron. The Politics of the Budgetary Process. Boston: Little Brown, 1964, p. 13-6.

${ }^{130}$ RUBIN, Irene. The Authorization Process: Implications for Budget Theory. In: (org.) New Directions in Budget Theory. Albany: ed. I. S. Rubin, 1988, p. 3.
} 
maioria dos participantes neste processo adota uma visão estreita do orçamento - uma visão guiada pela perspectiva fornecida por seu próprio terreno orçamentário" ${ }^{131}$. Aplicando-se a teoria à estrutura orçamentária brasileira, as unidades orçamentárias tendem a querer aumentar seus orçamentos, e o papel do órgão central (no caso federal, a Secretaria de Orçamento Federal - SOF) é equilibrar as pressões em jogo e fazer cortes. De outro lado, o Congresso Nacional pode até pressionar pelo equilíbrio fiscal, mas arriscará propor aumentos nas despesas que favorecem seu domicílio eleitoral. $\mathrm{O}$ incrementalismo confere destaque à importância das negociações estratégicas no processo orçamentário, na medida em que os participantes adotam estratégicas que os conduzem aos seus objetivos orçamentários, em que todos ganham um pouco e ninguém perde muito $^{132}$.

Seja o incrementalismo indicativo da regularidade do processo orçamentário ou do aumento (incremento) marginal da base orçamentária, certo é que se trata de fenômeno a exigir comprovação empírica. Este segundo aspecto é mais debatido, isto é, há mais espaço para a dúvida na afirmação de que a barganha orçamentária entre os poderes Executivo e Legislativo e entre os próprios órgãos componentes do Poder Executivo sempre conduz à salvaguarda da base orçamentária e se dá, em todos os casos, com o incremento moderado da despesa ${ }^{133}$. Se este ponto de vista é, porém, mais polêmico, será extremamente difícil encontrar um sistema orçamentário que não funcione num contexto de barganhas e negociações políticas. A teoria do incrementalismo se propõe, assim, como uma análise positiva, e não normativa, das decisões orçamentárias. Da mesma forma, tem seus méritos ao afirmar que este processo, ainda que influenciado por determinações "de cima para baixo", é evidentemente caracterizado por etapas "de baixo para cima", em que os diferentes órgãos burocráticos encarregados da decisão orçamentária se articulam, com base em seus respectivos âmbitos de atuação, para que sejam atendidos na formulação do orçamento. É, pois, comum que as propostas setoriais sejam estimadas para cima, já prevendo os cortes, o que colabora para o crescimento marginal das despesas setoriais típicas de um sistema incremental.

\footnotetext{
${ }^{131}$ BOZEMAN, B.; STRAUSSMAN, J. Shrinking Budgets and the Shrinkage of Budget Theory. Public Administration Review, v. 42, 1982, p. 510, tradução livre.

${ }^{132}$ BOZEMAN, B.; STRAUSSMAN, J. Shrinking Budgets and the Shrinkage of Budget Theory. Public Administration Review, v. 42, 1982, p. 510.

${ }^{133}$ LELOUP, L. The Myth of Incrementalism: Analytical Choices in Budgetary Theory. Polity, v. 10, n. 4, 1978, p. 494-5.
} 
Colocar decisões estratégicas em prática, como se vê, é um processo dificultado por este esquema rotineiro e simplificado de atuação sobre o orçamento público. Isto porque o papel dos órgãos da administração tende a ser conservador, atuando pela manutenção da base orçamentária disponível. O incrementalismo se mostra como um desafio à articulação entre planejamento e orçamento, pois a execução de mudanças desejadas esbarra num processo orçamentário atomizado em que os escalões mais setoriais e localizados da Administração são encarregados em muito maior grau da gestão cotidiana de seus orçamentos, buscando seu incremento, e menos da concretização de mudanças estruturais segundo estratégias definidas em níveis superiores.

As alterações orçamentárias que se mostrem necessárias ao longo da execução do orçamento (que é também a expressão financeira das metas de um plano, como visto, de acordo com a articulação dinâmica das leis orçamentárias segundo a Constituição) ficam também comprimidas em suas possibilidades de servirem aos interesses estratégicos do planejamento da ação governamental em razão dos limites trazidos por um processo orçamentário incrementativo. Como a ordem jurídica abre espaço para que as dotações orçamentárias continuem a ser debatidas mesmo depois do orçamento aprovado, não é razoável supor que as sucessivas barganhas políticas cessem quando o chefe do Executivo sanciona e promulga a lei orçamentária. Ao contrário, a política continua. E as unidades orçamentárias responsáveis por fazer as solicitações de aumento das despesas têm competências bastante delimitadas, de maneira que prevalece a posição de Bozeman e Straussman segundo a qual seus interesses ficam demasiadamente conscritos ao estrito âmbito de sua atuação, num conflito entre comandos de cima e sua execução pela base da burocracia administrativa, que também tem seus interesses (preservar o volume de recursos disponíveis para si). De outra parte, o contingenciamento de recursos e a possibilidade de aumentar algumas dotações orçamentárias apontam para a contínua possibilidade de negociações políticas ao longo da execução do orçamento. Estes temas serão esclarecidos em tópicos posteriores, mas sinalizam, desde já, a idéia de que, se as modificações orçamentárias devem ser feitas para permitir a concretização do orçamento e do plano aprovados diante de circunstâncias mutáveis que exigem sua revisão e atualização, isto não permanece como um objetivo plenamente concretizável segundo a estrutura vigente da flexibilidade da execução orçamentária - e, demonstrando-se o incrementalismo como um processo 
válido que explica como as decisões orçamentárias funcionam efetivamente, continua importante a questão de saber se esse quadro pode ser completamente alterado.

\subsection{A autoridade do Poder Legislativo sobre o orçamento}

Se o grau de separação entre os Poderes Legislativo e Executivo não é capaz de explicar, por si só, a extensão das competências parlamentares sobre o orçamento e sobre sua execução, diversos elementos específicos de cada sistema orçamentário precisam ser levados em consideração, tais como o sistema eleitoral, o bicameralismo, as limitações constitucionais e legais e mesmo as tradições, dentre outros ${ }^{134}$.

A análise do caso brasileiro demonstra que muitos dos problemas encontrados na fase de execução do orçamento podem ser grosseiramente sintetizados na oposição entre a manutenção das prerrogativas parlamentares sobre a decisão político-orçamentária e a discricionariedade do governo na realização dos gastos, a partir de suas proclamadas amplas competências nesta fase. Até aqui se procurou demonstrar que muitos dos argumentos invocados para sustentar a inclusão da gestão orçamentária no âmbito material de atividades privativas do Poder Executivo representam não apenas a reprodução de doutrinas estrangeiras ${ }^{135}$, mas, também e principalmente, a fossilização de teorias anacrônicas. Trata-se de uma dificuldade espaço-temporal.

É necessário, portanto, partir ao exame da Constituição brasileira para observar como aí se distribuiu o poder de executar o orçamento.

\subsubsection{Administração, lei e política}

Uma dificuldade intrínseca a todo sistema presidencial, no Brasil mantido em 1988 e reafirmado em plebiscito, é a conciliação da separação de poderes com a força do Poder Executivo. Uma visão panorâmica pode evidenciar que o governo presidencial tende a se transformar, pelo precário equilíbrio entre os poderes, num sistema em que

\footnotetext{
${ }^{134}$ LIENERT, I. Who Controls the Budget: the Legislature or the Executive?. Washington: International Monetary Fund (Working Paper), 2005. 26 p.

${ }^{135}$ Muitas vezes mitigadas, diga-se, nos locais de origem.
} 
prevalece o Poder Executivo. ${ }^{136}$ Não parece existir mais aquele modelo equilibrado, fruto da fusão "mágica"137 entre os princípios da força e vitalidade do Executivo (modelo hamiltoniano) e dos checks and balances (modelo madisoniano). A proeminência do chefe já fora observada por Kelsen, referindo-se a este elemento de concentração de poderes na figura do Chefe do Executivo e classificando a república presidencial entre as autocracias: "[a] monarquia constitucional e a república presidencial são democracias em que o elemento autocrático é relativamente forte. $\mathrm{Na}$ república com governo de gabinete e na república com governo colegiado, o elemento democrático é comparativamente mais forte." ${ }^{138}$

A extensão dos poderes presidenciais é amplamente reconhecida no Brasil, qualificados como "assoberbantes e esmagadores" "139. O Presidente da República é ora tratado como "a mais alta de todas as autoridades brasileiras" "140, ora como a "força motriz detentora do comando político da Nação"141. Isto tem suas razões de ser. Especificamente, os poderes do Chefe do Poder Executivo sobre o orçamento brasileiro sempre foram consideráveis, tanto no Império como na República.

É claro que, conquanto as expressões sirvam para dar destaque ao Presidente da República, não chegam a coincidir. Como Chefe de Estado, seu legítimo representante, é fácil de entender por que se trata da mais alta das autoridades brasileiras, ao passo que, ao menos juridicamente, a representação política não se pode identificar exclusivamente com a figura do Presidente. Os adjetivos parecem, porém, querer descrever um fato: o de que o Poder Executivo, em função de sua alta relevância na consecução das políticas de um Estado mais atuante, tem a primazia. Exprime, assim, uma precedência que não é de direito, mas de poder, o que faz recordar a afirmação de Lassalle de que "la verdadera Constitución de un país sólo reside en los factores reales y efectivos de poder que en ese país rigen". ${ }^{142}$ Tais fatores de poder, contudo, também se deslocam. ${ }^{143}$

\footnotetext{
${ }^{136}$ LUCARELLI, A. Teorie del Presidenzialismo: fondamento e modelli. Verona: Grafiche Fiorini, 2000, p. 212.

${ }^{137}$ LUCARELLI, A. Teorie del Presidenzialismo: fondamento e modelli. Verona: Grafiche Fiorini, 2000, p. 212.

${ }^{138}$ Teoria Geral do Direito e do Estado. Tradução de Luís Carlos Borges. São Paulo: Martins Fontes, 2005 , p. 428.

${ }^{139}$ BONAVIDES, P. Ciência Política. 10a ed. São Paulo: Malheiros, 2000, p. 298.

${ }^{140}$ FERREIRA FILHO, M. G. Curso de Direito Constitucional. 27a ed. São Paulo: Saraiva, 2001, p. 142.

${ }^{141}$ MORAES, A. Presidencialismo. São Paulo: Atlas, 2004, p. 12.

${ }^{142}$ LASSALLE, F. Que Es Una Constitución?. Tradução de W. Roces. Buenos Aires: Ediciones Siglo Veinte, 1946, p. 91.
} 
A despeito disso, não se pode esquecer que a legalidade é fundamento do regime democrático, constitucionalmente amparado. Mais ainda do que o princípio da separação de poderes, que não se identifica imediatamente com a democracia. Retomando Kelsen $^{144}$,

correspondente à ideia de democracia é a noção de que todo o poder deve estar concentrado no povo e, onde não é possível a democracia direta, mas apenas a indireta, que todo o poder deve ser exercido por um órgão colegiado cujos membros sejam eleitos pelo povo e juridicamente responsáveis para com o povo.

E ainda,

[c]aso este órgão tenha apenas funções legislativas, os outros órgãos que têm de executar as normas emitidas pelo órgão legislativo devem ser responsáveis para com ele, mesmo que também tenham sido eleitos pelo povo. É o órgão legislativo que tem o maior interesse numa execução rigorosa das normas por ele emitidas. (...) Portanto, a democracia exige que ao órgão legislativo seja dado controle sobre os órgãos administrativo e judiciário.

O jurista vienense reconhece, desta maneira, a prioridade do órgão legislativo em razão de ser ele a fonte de todas as normas de caráter geral, seja direta ou indiretamente, por meio dos órgãos aos quais delega competência legislativa.

Esta primazia é reconhecida também no direito constitucional pátrio, ainda que se dê destaque à figura central do Presidente da República. Em comentários à Constituição anterior, em pleno regime autoritário, é de Manoel Gonçalves Ferreira Filho $^{145}$ a observação de que

[o] Legislativo é o primeiro dos Poderes, segundo a clássica separação dos Poderes que estrutura o Estado, em função da lei, desde que, em linhas mestras, incumbe ao Executivo fazê-la cumprir e ao Judiciário aplicá-la, contenciosamente. Logicamente, pois, o Poder que declara a lei tem precedência e, mais do que isso, preeminência sobre os demais.

É certo que o poder como função e o poder como órgão nem sempre coincidem, em razão de maneiras específicas de distribuição de competências. Ocorre que o Poder

${ }^{143}$ LASSALLE, F. Que Es Una Constitución?. Tradução de W. Roces. Buenos Aires: Ediciones Siglo Veinte, 1946, p. 85.

${ }^{144}$ Teoria Geral do Direito e do Estado. Tradução de Luís Carlos Borges. São Paulo: Martins Fontes, 2005, p. 403.

${ }^{145}$ Comentários à Constituição Brasileira. $5^{\text {a }}$ ed. São Paulo: Saraiva, 1984, p. 186. 
Legislativo, como órgão legislativo da União, recebeu atribuições para elaborar leis sobre todas as matérias de competência da União, conforme especifica o art. 48, além de atribuições deliberativas, fiscalizadoras, jurisdicionais e constituintes ${ }^{146}$. A distribuição de competências entre os Poderes reservou ao Presidente da República, por sua vez, competências privativas explícitas (art. 84), posto que se possam reconhecer outras, decorrentes de sua própria posição constitucional. A opinião de que apenas o Poder Executivo exerce competências na execução orçamentária, todavia, carece de uma fundamentação sistemática mais sólida.

A execução orçamentária é a execução de uma lei - a lei de orçamento. Trata-se, portanto, de uma atividade administrativa, concebendo-se a administração pública em seu sentido objetivo: um conjunto abrangente de atos que se destina à satisfação das necessidades coletivas. Mais pontualmente, a satisfação das necessidades previstas no orçamento. Além deste, a Administração Pública tem também seu sentido orgânico ou subjetivo: expressa uma organização composta por diversos sujeitos, numerosas entidades e órgãos públicos. ${ }^{147}$

Em seu sentido material, a administração pública tem por escopo realizar concretamente objetivos definidos pela política, que tem natureza intrinsecamente criadora. À política cabe inovar, em "carácter livre e primário", ao passo que a administração pública tem "carácter condicionado e secundário, achando-se por definição subordinada às orientações da política e da legislação." ${ }^{148}$ Política e legislação colocam-se, assim, num mesmo plano, de modo que a distinção que há entre administração pública e política é a mesma que se encontra entre administração pública e legislação. Daí que a lei seja o fundamento e o limite de toda atividade administrativa. A vinculação dos poderes administrativos a um fim impessoal faz com que as competências sejam, necessariamente, a manifestação do direito objetivo, não se podendo cogitar que a pessoa administrativa tenha algum direito subjetivo público à competência. ${ }^{149}$ Segundo esta sistemática, não é concebível que o exercício de uma atividade administrativa possa alterar os objetivos previstos em lei. Tampouco, por

\footnotetext{
${ }^{146}$ SILVA, J. A. Curso de Direito Constitucional Positivo. $34^{\text {a }}$ ed. São Paulo: Malheiros, 2011, p. 520-1.

${ }^{147}$ Cf., por todos, AMARAL, Diogo Freitas do. Curso de Direito Administrativo. $2^{\mathrm{a}}$ ed. Coimbra: Almedina, 2004. v. 2, p. 32 e ss.

${ }^{148}$ AMARAL, Diogo Freitas do. Curso de Direito Administrativo. $2^{\mathrm{a}}$ ed. Coimbra: Almedina, 2004. v. 2, p. 46.

${ }^{149}$ CIRNE LIMA, Ruy. Princípios de Direito Administrativo. $7^{\text {a }}$ ed. São Paulo: Malheiros, 2007, p. 385.
} 
extensão, que, no exercício da competência administrativa de executar o orçamento, se possa inovar o orçamento. Sendo o orçamento ao mesmo tempo lei e a expressão de uma política, somente por estas vias se pode proceder à revisão de suas finalidades.

Dentre as atribuições do Presidente da República, encontram-se, dentre outras, aquelas de natureza administrativa. Constitui "órgão constitucional (supremo) que tem por função a prática de atos de chefia de estado, de governo e de administração" ${ }^{150}$. Ainda, por razões de índole técnica, mas com profundo impacto político, compete ao Executivo o impulso do processo legislativo especial das leis orçamentárias. A Constituição Federal estabelece que leis de iniciativa do Poder Executivo estabelecerão o Plano Plurianual, as Leis de Diretrizes Orçamentárias e a Lei Orçamentária Anual (art. 165 e incisos). Também há dispositivo constitucional que cuida de prever lei complementar para dispor sobre prazos e a elaboração destas leis ( $\$ 9^{\circ}$ do art. 165), que ainda não foi editada. Diante deste quadro, normas transitórias da Constituição continuam em vigor, assim como a legislação referente pretérita não revogada.

Como chefe do Poder Executivo, é o Presidente da República que encaminha a proposta orçamentária ao Congresso, na esfera federal, por meio de Mensagem. Não há na Constituição, porém, especificação dos papeis de outros agentes do Poder Executivo, cuja participação na elaboração orçamentária é de fundamental importância para o produto final deste processo, que é a proposta orçamentária. Como é próprio da Administração Pública, trata-se de processo hierarquizado em que diferentes órgãos devem desempenhar funções especificadas principalmente por normas infralegais.

As competências de elaboração do orçamento são, basicamente, desempenhadas pelo chefe do Executivo e pelo órgão central de controle, organização e preparação do orçamento. Na esfera federal, o órgão central é a Secretaria de Orçamento Federal (SOF), ligada ao Ministério do Planejamento, Orçamento e Gestão (MPOG), que, dentre outras atribuições, é responsável pelo planejamento do processo de elaboração.

Primeira conclusão que disse se extrai é que não se deve identificar a execução orçamentária com o Chefe do Poder Executivo, mas com toda a Administração Pública, de quem aquele exerce a direção superior (art. 84, II). Outra consequência é que a

\footnotetext{
${ }^{150}$ SILVA, J. A. Curso de Direito Constitucional Positivo. 34 a ed. São Paulo: Malheiros, 2011, p. 520-1, p. 542.
} 
previsão de que o Executivo, congregando esforços de toda a Administração, elabore a proposta orçamentária expõe a inocuidade do argumento de que uma estrita vinculação do Executivo ao orçamento poderia inviabilizar a ação administrativa. Qualquer sistema racional de execução orçamentária preverá instrumentos de flexibilidade. Além disso, a obrigação positiva de cumprir a lei de orçamento representaria não mais que a obrigação de executar objetivos que o governo mesmo traçou, por meio de suas competências na fase de elaboração, com todas as possibilidades de ajustar o orçamento à conjuntura. Ocorre que esta decisão é a alteração de uma política, que logicamente deve ser anuída pelo órgão legislativo a quem incumbe aprová-la definitivamente com caráter de lei.

A concordância do Parlamento com as políticas orçamentárias, que em determinadas hipóteses podem ser alteradas, as colocam num plano subordinante da atividade administrativa subsequente. Ainda, dizer que a execução orçamentária compete ao Poder Executivo não pode significar que esta seja uma competência exclusiva, presumida a partir da natureza administrativa de sua atividade. Esta se subordina a diretrizes delineadas pelo Poder Legislativo, e a competência de iniciar o processo legislativo das leis orçamentárias está aí, de qualquer forma, para assegurar ao governo, com as informações técnicas de que dispõe, participação no resultado do trabalho parlamentar. Exercendo-se a competência nos limites constitucionais, a ampliação das prerrogativas parlamentares e a própria mudança de funções do orçamento podem conferir ao Poder Legislativo a condição de participante de diversas decisões da execução orçamentária, como já está previsto na Constituição em alguns casos de modificações do orçamento. Abre-se o próximo tópico, porém, para que tais competências orçamentárias referentes ao orçamento fiquem menos abstratas.

\subsubsection{Competências orçamentárias do Poder Legislativo}

A Constituição Federal conferiu importantes competências orçamentárias ao Poder Legislativo, nomeadamente no que se refere à aprovação da proposta orçamentária. Além de submeter o orçamento das empresas estatais e da seguridade social à apreciação parlamentar, unificando os orçamentos públicos, compreendeu as leis orçamentárias referentes ao planejamento e às diretrizes entre aquelas que serão objeto do crivo do Parlamento, além do orçamento propriamente anual propriamente 
dito. Ademais, no que se refere aos agentes deste processo, a Constituição reafirmou salutar princípio de organização do processo legislativo orçamentário, que é votação do orçamento, da lei de diretrizes orçamentárias, do plano plurianual e dos créditos adicionais $^{151}$ em sessão conjunta da Câmara dos Deputados e do Senado Federal, na forma do regimento comum, de modo a evitar os problemas decorrentes de propostas orçamentárias diferentes aprovadas por cada uma das Casas. ${ }^{152}$

Outro aspecto importante a destacar é que, além de tratar da participação da Câmara dos Deputados e do Senado Federal no processo legislativo orçamentário federal, a Constituição deu importantes funções à Comissão Mista de Orçamento (CMO), à qual compete examinar e emitir parecer sobre os projetos de PPA, LDO, LOA e créditos adicionais, sobre as contas apresentadas anualmente pelo Presidente da República, sobre os planos e programas nacionais, regionais e setoriais constitucionalmente previstos, além de acompanhar e fiscalizar o orçamento, sem prejuízo da atuação de outras comissões de cada uma das Casas do Congresso ${ }^{153}$.

Merecem particular atenção as Resoluções n. ${ }^{\circ} 1 / 91$ e n. ${ }^{\circ} 1 / 92$ do Congresso Nacional, que deram início à instituição de normas básicas de funcionamento desta Comissão Mista (a primeira), aperfeiçoando-a depois (a segunda), com o objetivo de possibilitar que a análise da proposta orçamentária se pudesse dar com condições adequadas, sem a necessidade de recorrer a servidores técnicos do Poder Executivo. No mesmo ano de 1992, o Congresso adotou um padrão de parecer preliminar, melhorado nos anos seguintes, para que os procedimentos se dessem de maneira transparente, com regras claras, uniformes e não superpostas, limitando o poder do relator ${ }^{154}$.

Apesar destes avanços, porém, a lei complementar prevista pelo art. 165 , §9 , da Constituição, não foi editada, estando ainda em vigor a Lei 4.320/64, elaborada numa época em que não havia previsão do PPA e da LDO. Afora isso, algumas outras dificuldades administrativas, apontadas por Sanches ${ }^{155}$, persistem no que tange à

\footnotetext{
151 Com exceção dos créditos extraordinários, cujo trâmite legislativo é o das medidas provisórias, segundo a própria Constituição (art. $166, \S^{\circ}$ ). São, portanto, deliberados separadamente pelas Casas do Congresso.

${ }^{152}$ Art. 166 da Constituição.

${ }^{153}$ Art. $166, \S 1^{\circ}$, incisos I e II, da Constituição.

${ }^{154}$ SANCHES, Osvaldo M. Processo orçamentário federal: problemas, causas e indicativos de solução. Revista de Administração Pública, Rio de Janeiro, v. 29, n. 3, jul./set. 1995, p. 2.

${ }^{155}$ SANCHES, Osvaldo M. Processo orçamentário federal: problemas, causas e indicativos de solução. Revista de Administração Pública, Rio de Janeiro, v. 29, n. 3, jul./set. 1995, p. 2.
} 
organização da CMO. As operações desta Comissão não são adequadamente articuladas com outras comissões permanentes da Câmara e do Senado, com definição clara de prazos para apreciação da proposta no plenário da CMO e do Congresso Nacional, além da precariedade do assessoramento colocado à disposição pela Comissão. Há, ainda, outras dificuldades técnicas relativas à precariedade da articulação intergovernamental, a ineficácia do Plano Plurianual, a utilização da LDO abaixo de seu potencial etc. ${ }^{156}$

Nada autoriza a afirmação de que o Poder Legislativo não tem papeis constitucionais relevantes no orçamento público. Seu papel não é apenas o exercício do controle democrático do Executivo, o que já seria importante, mas também, em diversos momentos, decidir definitivamente sobre suas propostas. No campo orçamentário, isto é claro em vista da competência de modificar a proposta encaminhada, nos limites constitucionais (art. 166, $\S \S 2^{\circ}$ e $3^{\circ}$ ). Da mesma forma, cabe-lhe aprovar a abertura de créditos adicionais (art. 167, $\mathrm{V}$ e $\S 3^{\circ}$ ) ou a transferência de recursos entre dotações orçamentárias (art. 167, VI), de maneira a preservar a integridade da participação legislativa no processo orçamentária. Cabe-lhe, da mesma forma, zelar pelo cumprimento do orçamento aprovado em razão da inafastabilidade de suas prerrogativas constitucionais: a qualquer momento pode a CMO solicitar esclarecimentos à autoridade governamental responsável pela execução de despesa com indícios de que não tenha sido autorizada (art. 72).

Mas, sobretudo, a possibilidade de participação do Poder Legislativo na fase de execução orçamentária se dá pela própria sistemática de separação de poderes atualmente em vigor: se quisesse a Constituição transformar a execução orçamentária em competência privativa do Chefe do Poder Executivo, sem interferência do Parlamento, por que não o teria explicitado na Constituição, visto que se deu ao trabalho de mencionar as competências da elaboração, da aprovação e do controle? E a resposta parece ser que, pela autoridade constitucional do Parlamento, de quem depende a aprovação da lei orçamentária, é admissível que dele possam depender também todas as suas alterações, conferindo-lhes a legitimidade de que se trata de uma decisão autorizada pelos representantes do povo em um regime democrático. O contrário seria admitir que a definição de objetivos expressa na lei orçamentária é um simulacro

\footnotetext{
${ }^{156}$ SANCHES, Osvaldo M. Processo orçamentário federal: problemas, causas e indicativos de solução. Revista de Administração Pública, Rio de Janeiro, v. 29, n. 3, jul./set. 1995, p. 3.
} 
anterior às decisões que efetivamente atenderiam ao interesse nacional, tomadas no Poder Executivo. A precedência do Parlamento não pode conduzir a esta conclusão.

Isto não chega a ser um problema com relação a parte dos créditos adicionais e outros mecanismos de alteração do orçamento que já dependem de autorização legislativa prévia e específica. Com relação a outros instrumentos de flexibilidade, todavia, há diversos problemas e dificuldades à conservação das prerrogativas parlamentares sobre o orçamento. É relevante, portanto, explorar melhor a compatibilidade que deve haver entre a lei orçamentária e sua execução, para depois seguir ao exame específico dos instrumentos de flexibilidade. 


\section{FINALIDADES DA EXECUÇÃO ORÇAMENTÁRIA}

A execução do Orçamento é o "conjunto de atividades destinadas ao cumprimento dos programas estabelecidos para alcançar os objetivos propostos"157. Quanto mais estreita a associação entre planejamento e orçamento, destacando-se a técnica do orçamento-programa, maior tende a ser o envolvimento de todos órgãos da Administração, estabelecendo as unidades orçamentárias que serão responsáveis tanto pela programação como por sua execução.

Num sistema de execução orçamentária que se fundamente na atribuição de competências a diferentes agentes, normalmente situados no âmbito do Poder Executivo por seu caráter administrativo, esta divisão deve ser tão clara quanto possível, de modo a evitar superposição e a consequente redução da eficiência da organização administrativa. Com isto, ganhou bastante importância não apenas no Brasil, mas em diversos outros sistemas orçamentários, uma tradicional divisão de funções e responsabilidades entre a unidade programadora e a unidade executora. Cabe àquela a programação e a coordenação das atividades do órgão que deve executar o programa, estabelecendo o fim de cada projeto, as prioridades e a administração dos créditos orçamentários, se a legislação que a rege o permitir. Compete à unidade executora a consecução dos projetos, sob a perspectiva da construção das unidades físicas que cada um deles objetiva.

Diz-se tradicional, porque a distinção é bem desenvolvida em outros sistemas jurídico-orçamentários. As normas referentes à gestão das finanças públicas na França se eximem em destacar a diferença fundamental que deve haver entre o ordonnateur e o comptable. Promove-se uma divisão orgânica e funcional de competências, permitida pela independência entre as autoridades e pela incompatibilidade entre as funções exercidas. O objetivo nítido é assegurar o controle da regularidade e da legalidade da execução da despesa ${ }^{158}$.

O sistema não é imune a críticas, em vista da influência que adquirem os conceitos gerenciais aplicados à Administração Pública. A estrita separação acima apontada, fundada no apropriadamente denominado "princípio da desconfiança"

\footnotetext{
${ }^{157}$ SILVA, José Afonso da, Orçamento Programa no Brasil. São Paulo: RT, 1973, p. 306-7.

${ }^{158}$ BOUVIER, M.; ESCLASSAN, M.-C.; LASSALE, J.-P. Finances Publiques. $7^{\mathrm{a}}$ ed. Paris: LGDJ, 2004, p. 371.
} 
(principe de la méfiance), em razão do excesso de procedimentos adotados a priori na execução da despesa, assegura o controle da regularidade formal, mas não fornece respostas adequadas à necessidade de eficiência e de desempenho da gestão pública, determinando procedimentos morosos, trabalhosos e excessivamente formalistas - o que pode ser em parte corrigido já pela informatização dos serviços de administração financeira e orçamentária ${ }^{159}$. A revisão deste sistema tem, como escopo mais evidente, dar maior liberdade à ação dos agentes, com máxima eficácia aos menores custos. Se eficiência, eficácia e efetividade são objetivos desejados para a Administração Pública, a "desconfiança", porém, é de alguma forma justificada quando se trata de agentes que cuidam do dinheiro alheio - pelo que, se há méritos inequívocos nas propostas de administração gerencial, o problema dos desvios no uso do dinheiro público precisa ser corrigido em várias frentes de atuação, e não apenas no procedimento de empenho e pagamento da despesa. E, ainda mais, não só quanto aos procedimentos administrativos, mas também quanto aos políticos. Começar as reformas unicamente por diminuir a responsabilidade do ordenador da despesa, que deve verificar sua regularidade, sem promover outras modificações mais amplas na transparência, na eficiência dos sistemas de controle interno e externo exercidos sobre o desempenho, e sem introduzir instrumentos de efetiva responsabilidade dos agentes públicos e de participação democrática no sistema orçamentário, significaria apenas a indesejável substituição do "princípio da desconfiança” pelo "princípio da ingenuidade”.

Quanto aos objetivos, em termos bastante abrangentes se pode considerar que a execução da lei orçamentária tem os mesmos objetivos da execução de qualquer lei: cabe ao Poder Executivo aplicar as leis aprovadas pelo Congresso, remetendo-se ao desenvolvido no item 2.1.6.1. O exercício da atividade administrativa encontra limites na inovação das providências políticas e legislativas, e o orçamento, por suas diversas características, se enquadra em ambas. No Brasil, tradicionalmente não se prevê a figura dos regulamentos autônomos ${ }^{160}$. O inciso IV do art. 84 da Constituição Federal dispõe que compete privativamente ao Presidente da República expedir decretos e regulamentos para a "fiel execução" da lei, pelo que há razão em afirmar que o poder conferido ao Executivo na execução das leis é um poder subordinado.

\footnotetext{
${ }^{159}$ BOUVIER, M.; ESCLASSAN, M.-C.; LASSALE, J.-P. Finances Publiques. $7^{\mathrm{a}}$ ed. Paris: LGDJ, 2004, p. 383.

160 Com exceção do art. 84, inciso VI, da Constituição, que prevê a expedição de decretos para organização e funcionamento da administração federal, quando não implicar aumento de despesa nem criação ou extinção de órgãos públicos.
} 
O orçamento provavelmente lidará com necessidades urgentes e imprevistas no decorrer de sua vigência, que demandarão a abertura de crédito específico a atendê-las. Ou enfrentará circunstâncias financeiras imperiosas que exigirão o bloqueio ou desbloqueio de créditos já votados e, muitas vezes, já empenhados. Qualquer que seja a circunstância imperiosa, não são meras hipóteses os casos em que o Poder Executivo se verá na iminência de tomar decisões executórias da lei de orçamento. Em sistemas mais confortáveis com a idéia de regulamentos autônomos, tais como o francês, vale mesmo a afirmação de Trotabas e Cotteret, segundo quem o atendimento destas necessidades poderia ocorrer até sem autorização legislativa para o pronto atendimento de necessidades públicas ${ }^{161}$.

No caso brasileiro, a afirmação de que a lei de orçamento é uma autorização de gasto para o Poder Executivo poderia produzir o entendimento, aqui anteriormente já contestado, de que não cabe ao Poder Legislativo atuar na fase de execução, que envolveria a produção de atos materialmente administrativos. Não se podem ignorar alguns dos escrúpulos existentes quanto à maior participação do Legislativo na execução, que fazem entender e repetir, como uma vulgata do direito orçamentário, que o Executivo é mais responsável.

Inegavelmente, o problema central que subjaz às atribuições do Poder Executivo é a dificuldade de conciliar as prerrogativas de controle parlamentar com maior flexibilidade da gestão orçamentária. Se, de um lado, o orçamento tem uma função jurídica, que enfatiza a conformidade de todas as despesas com as normas e critérios postos, tem também uma função político-econômica, que é a de servir como instrumento de governo. A despeito da aparência de obviedade destes aspectos, eles não são conciliáveis em todas as suas dimensões.

Veja-se que a função jurídica do orçamento, considerada no extremo de uma estrita obrigação de gastar, pode produzir um indefectível sistema de controle de regularidade dos gastos governamentais, perfeitamente condizente com a previsão inicial que foi aprovada pelo Poder Legislativo. Isto, porém, em detrimento da eficiência da realização de um programa econômico, que deve ser em alguma medida adaptável à conjuntura e aberto a revisões ocasionais. Tais necessidades de alteração,

${ }^{161}$ Cf. TROTABAS, L.; COTTERET, J. Droit Budgétaire et Comptabilité Publique. $5^{\mathrm{a}}$ ed. Paris: Dalloz, 1995, p. 102. 
sendo a expressão de um meio de atender ao interesse público em cumprimento de determinada política, necessitam encontrar o procedimento alterado para sua concretização. Uma forte rigidez da execução orçamentária. Pode-se verificar que uma restrita à aplicação técnica dos aspectos mais formais da realização da despesa, trouxe uma série de dificuldades ao sistema orçamentário italiano, até a década de 1990, e ao polonês, nos quais o poder do Ministério da Fazenda se restringia a considerações formais sobre o procedimento, sem a necessária consideração sobre os aspectos do ambiente em que se insere o orçamento ${ }^{162}$.

No mais das vezes, esse tipo de normatividade rígida, no mais das vezes forçando ao cumprimento do equilíbrio orçamentário por meio do controle das despesas, pode ter por resultado a limitação da capacidade de resposta eficiente do governo a situações imprevistas. Além disso, se esta rigidez é tantas vezes normatizada com a finalidade de conferir credibilidade a determinado país, pode-se chegar à situação contrária de perda de credibilidade se os parâmetros são tão intransigentes ${ }^{163}$.

De outro lado, é claro que um sistema de execução do orçamento demasiadamente flexível enfraquece qualquer controle que as normas atinentes exerçam sobre a conduta do agente encarregado de conduzir a implementação dos gastos públicos.

O importante trabalho de Jesse Burkhead sobre o orçamento público expõe claramente o desafio de conciliação entre as duas noções citadas, dizendo que a execução do orçamento deve preservar a intenção do legislador e, ao mesmo tempo, manter a flexibilidade. A definição ideal parece simples, mas difícil de atingir ${ }^{164}$. A grande questão da execução do Orçamento é reduzir a incompatibilidade que há na manutenção da vontade parlamentar expressa na lei aprovada e mantê-la, ao mesmo tempo, maleável. Reduzir, portanto, o tradeoff existente entre a rigidez normativa da lei orçamentária e a eficiência requerida para dar respostas a situações imprevistas.

\footnotetext{
${ }^{162}$ VON HAGEN, J. Budgeting Institutions for Better Fiscal Performance. In: SHAH. A. (ed.) Budgeting and Budgetary Institutions. Washington: The World Bank, 2007, p. 32.

${ }^{163}$ VON HAGEN, J. Budgeting Institutions for Better Fiscal Performance. In SHAH. A. (ed.) Budgeting and Budgetary Institutions. Washington, The World Bank, 2007, p. 32

${ }^{164}$ BURKHEAD, Jesse. Government Budgeting. New York: John Wiley \&Sons, 1956, p. 342.
} 
Esta dificuldade de conciliação dá o tom dos objetivos que devem ser perseguidos pela execução do orçamento, que é marcada por diferentes características. Resumiu Duverger ${ }^{165}$ que,

\begin{abstract}
[e]m definitivo, a execução do orçamento é sempre dominada essencialmente por três espécies de considerações. Considerações políticas, em primeiro lugar: assegurar o respeito às prerrogativas do Parlamento em matéria financeira, evitando ultrapassar as autorizações orçamentárias. Considerações financeiras, em seguida: impedir esbanjamento e malversação por parte dos agentes encarregados da execução do orçamento. Considerações administrativas, enfim: assegurar uma boa gestão dos serviços públicos.
\end{abstract}

Uma conclusão que se pode obter a esta altura é que cabe falar em flexibilidade na fase de execução do orçamento apenas quando ela encontra espaço de atuação. Não é possível entender, porém, que haja uma contradição entre flexibilidade e legalidade: se não à execução rigorosa dos montantes, as alterações devem se destinar à manutenção dos objetivos políticos contidos no orçamento. Tais objetivos, como já desenvolvido, subordinam decisões executórias do orçamento, e não se pode entender que haja uma irredutível oposição entre a política orçamentária do Poder Legislativo e a política orçamentária do Poder Executivo. As medidas de execução ficam adstritas à obtenção dos resultados previstos nos programas orçamentários, quer para isso seja necessário gastar todo o dinheiro previsto para ele ou não. A flexibilidade não opere num vácuo de princípios orçamentários, e tampouco os interesses do Poder Executivo em realizar determinada política fiscal pode se abstrair dos objetivos orçamentários. O sistema mostra-se de alguma forma complexo, mas a relação do orçamento com outras leis orçamentárias, com destaque para a LDO, acrescidos os dispositivos previstos na LRF, não permite dizer que o cumprimento dos objetivos do orçamento comprometeria a política econômica necessária ao melhor interesse do país, pois que o orçamento não é fechado à necessidade de adequações ao ambiente econômico. Entretanto, o Poder Legislativo não pode ser ignorado.

Para entender a flexibilidade, é necessário situá-la face a outros princípios, nomeadamente a transparência, a anualidade e a especificação.

\footnotetext{
${ }^{165}$ DUVERGER, M. Finances Publiques. Paris: Presses Universitaires de France, 1975, p. 304, tradução livre.
} 


\subsection{Limites jurídicos à flexibilidade da execução orçamentária}

\subsubsection{O princípio da transparência}

A flexibilidade se encontra em estreita conexão com o princípio da transparência. Ainda que este seja bastante amplo e abarque uma diversidade de situações e aspectos, por ele se indica que a projeção das receitas e das despesas deve ser estabelecida de acordo com circunstâncias reais, na medida em que estas se deixem prever $^{166}$. O objetivo é limitar a distância existente entre os resultados esperados e efetivos da conduta orçamentária.

Outras denominações são dadas ao princípio da transparência conforme sejam destacados alguns de seus aspectos mais específicos: fala-se em princípio da sinceridade, da exatidão, da veracidade e da honestidade da estimativa orçamentária. No Brasil, tem sido expresso mais consistentemente como princípio da transparência, propriamente, desenvolvendo-se notavelmente com a LRF. Diversas orientações internacionais o aconselham, inclusive quanto ao controle de subvenções e renúncias de receitas, que poderiam, de outra forma, ser facilmente ocultáveis ${ }^{167}$. Estabeleceu-se, em seu art. $1^{\circ}$, que a responsabilidade na gestão fiscal pressupõe ação planejada e transparente. A previsão da publicidade como princípio da administração pública pelo art. 37 igualmente o corrobora, mas há outros dispositivos específicos, tais como a previsão de que as contas dos Municípios devem ficar abertas, durante 60 dias, anualmente, à disposição de qualquer contribuinte, para exame e apreciação (art. 31, $\S 3^{\circ}$ ), e pela previsão de que a lei determinará medidas para que os consumidores sejam esclarecidos acerca dos impostos que incidem sobre mercadorias e serviços (art. 150, $\S 5^{\circ}$ ). É um princípio que vincula o Estado à Sociedade, consubstanciando-se "na clareza orçamentária, na responsabilidade fiscal, no respeito aos direitos do contribuinte no aperfeiçoamento da comunicação social e no combate à corrupção dos agentes públicos" ${ }^{\prime 68}$.

\footnotetext{
166 NEUMARK, F. Der Reichshaushaltplan: ein Beitrag zur Lehre vom öffentlichen Haushalt. Jena: Verlag von Gustav Fischer, 1929, p. 251-2.

167 INTERNATIONAL MONETARY FUND. Code of Good Practices on Fiscal Transparency. Washington: IMF, 2007.

168 TORRES, R. L. Tratado de Direito Constitucional, Financeiro e Tributário: Orçamento na Constituição. $2^{\mathrm{a}}$ ed. Rio de Janeiro: Renovar, 2000. v. 5, p. 209.
} 
A exatidão das informações contidas no orçamento é também expressão nítida do princípio da unidade orçamentária, previsto pelo art. $165, \S 5^{\circ}$, da Constituição, e que se presta fundamentalmente à transparência das informações financeiras. A inclusão das despesas e receitas no orçamento público manifesta-se pela sua perspectiva de completude. Um orçamento incompleto consiste habitualmente em estimativas imprecisas, do tipo que se observa em cálculos empurrados para baixo ou em receitas ou despesas simplesmente omitidas. Apesar desta conexão, porém, o princípio da transparência permite afirmar sua independência do princípio da unidade. Se, por exemplo, as dotações orçamentárias relativas a certas despesas forem estimadas em níveis significativamente mais altos do que as circunstâncias exigiriam, não haveria nenhuma violação ao princípio da unidade ou da completude, mas haveria nítida discordância com o princípio da transparência.

Este princípio tem grande importância para as funções que o orçamento deve cumprir. Sua inobservância compromete o equilíbrio orçamentário: as estimativas incompletas prejudicam uma relação harmônica duradoura entre receita e despesa, pois os resultados distintos obtidos na realidade provocam maior número de perturbações. De um ponto de vista político, ainda, a situação financeira ao tempo da aprovação do orçamento fica encoberta tanto ao Parlamento como à Sociedade. A Administração não apenas se retira, por meio da insinceridade, da esfera de controle parlamentar, mas também induz o Poder Legislativo a erro nas decisões políticas que precisem ser tomadas. Por exemplo, a subestimação de despesas pode convencer o parlamento da necessidade de realização de operações de crédito; de outra parte, sua superestimação pode conduzi-lo a abdicar da criação de um programa que corresponda à sua vontade, sob o argumento de que não há recursos, apenas por inconveniência à Administração.

O princípio tem consequências econômicas e políticas claras. Nunca teve dificuldades em se afirmar como uma necessidade prática, porém nem sempre encontrou reconhecimento teórico. Sua importância é, hoje, cada vez mais reconhecida em razão do desenvolvimento de novas técnicas de Administração gerencial do setor público, que valorizam conceitos como a accountability e a maior participação da sociedade em públicas públicas, o que a transparência pode estimular. ${ }^{169}$ A inexatidão

\footnotetext{
${ }^{169}$ ALMEIDA, C. O. F. O Planejamento Financeiro Responsável: boa governança e desenvolvimento no estado contemporâneo. In: CONTI, J. M.; SCAFF, F.F. Orçamentos Públicos e Direito Financeiro. São Paulo: RT, 2011, p. 595.
} 
da previsão orçamentária representa uma enorme dificuldade à prestação de contas, à análise de informações e ao controle de desempenho dos programas orçamentários.

Por meio da previsão reduzida das receitas ou de estimativa maior da despesa, a Administração abre espaço para a criação posterior de despesas adicionais suplementares ou completamente novas. Ainda, o governo deve recorrer ao contingenciamento de despesas já empenhadas caso a arrecadação se mostre insuficiente naquele determinado tempo.

Flexibilidade e transparência se implicam mutuamente, sem que haja entre elas contradição. Admitir a possibilidade de que os instrumentos de flexibilidade da execução orçamentária servissem para dar cobertura às consequências de uma previsão orçamentária insincera é incoerente com o princípio da transparência. A flexibilidade da execução orçamentária, traduzida em alterações no orçamento votado no curso do exercício financeiro em que vige, deve significar uma adaptação a situações que não puderam ser previstas ou que se fazem urgentes e imperiosas. O contrário significaria fazer da flexibilidade o salvo-conduto do administrador desonesto, ou ainda tornar a habilidade em manipular dados financeiros do Estado uma vantagem política competitiva. A flexibilidade não pode ser aí entendida como princípio oposto à transparência, mas como um instrumento de correção de erros técnicos, de adaptação à conjuntura para a realização do plano aprovado e de realização de despesas inevitáveis, no cumprimento estrito dos requisitos que a Constituição e a legislação orçamentária lhe impõem. A transparência orçamentária, além disso, permite saber com mais clareza a produtividade e a eficiência do gasto, podendo servir à sua redução. Pode indicar, portanto se acréscimos nas dotações durante a execução é realmente uma medida necessária. $^{170}$

\subsubsection{O princípio da especialidade}

O princípio da especialidade (ou da especificação, ou da especialização) do orçamento público é habitualmente tratado em seu aspecto material. Deve-se

\footnotetext{
${ }^{170}$ RUBINSTEIN, F. Notas Sobre a Transparência Fiscal no Direito Financeiro. CONTI, J. M.; SCAFF, F.F. Orçamentos Públicos e Direito Financeiro. São Paulo: RT, 2011, p. 880.
} 
reconhecer, entretanto, que o conceito de especialidade para o orçamento (em particular para a execução orçamentária) tem duplo desdobramento, tanto material como temporal.

A simples norma que estabelece que orçamento vale para um exercício financeiro já expressa um tipo de especialidade temporal que faz com que o orçamento seja intrinsecamente específico. Isto o reconheceu, em trabalho bastante antigo, Boiteau: "o orçamento é, em si mesmo, uma primeira especialidade"171. Ao lado deste aspecto temporal, encontra-se também especialidade material nos casos em que se deseja que as estimativas orçamentárias da imensa quantidade de operações financeiras de uma comunidade política adquiram articulação e ordem. No lugar da multiplicidade arbitrária, busca-se a escolha racional de fins; somente poderão ser executadas aquelas despesas que tiveram sua estimativa discriminada no orçamento. Os meios públicos devem ser empregados não em montantes aleatórios, mas de acordo com a maneira pela qual determinada quantidade de dinheiro foi alocada para um fim específico.

\subsubsection{A especialidade temporal: o exercício financeiro e atenuações ao} princípio da anualidade da despesa

Está disposto no art. $165, \S 9^{\circ}$, da Constituição, que lei federal disporá sobre o exercício financeiro. A Lei 4.320/64, posto que seja anterior ao texto constitucional vigente, disciplina o comando mencionado. Seu art. 34 estabelece que o exercício financeiro coincidirá com o ano civil.

Levantamento feito por James Giacomoni expõe detalhadamente as inúmeras alterações que sofreu o exercício financeiro no Brasil, nem sempre coincidindo com o ano civil. Sua superposição, porém, foi reafirmada pela Lei 4.320/64, a qual consolidou a regra prevista na lei anterior. ${ }^{172} \mathrm{O}$ percurso cronológico demonstra que a realização de operações de receita e despesa pode não seguir, e dificilmente segue, a previsão inicial contida na lei de orçamento. Esta margem de imprecisão levou a legislação financeira brasileira, em diversos momentos da sua história, a prolongar o exercício financeiro em relação ao ano civil para possibilitar que lançamentos retardatários de receita ou

\footnotetext{
${ }^{171}$ BOITEAU, P. Budget Général de l'Etat. In: SAYS, L. Dictionnaire des Finances. Paris: BergerLevrault, 1889. v. I, p. 611, tradução livre.

${ }^{172}$ GIACOMONI, J. Orçamento Público. $15^{\mathrm{a}}$ ed. São Paulo: Atlas, 2005, p. 296 e ss.
} 
despesas empenhadas, mas ainda não pagas, pudessem ocorrer posteriormente, num sistema contábil mantido em aberto por mais tempo. Atualmente, ainda que não se preveja a prorrogação do exercício, ocorre efeito parecido, na prática, mediante a inscrição de restos a pagar no orçamento do ano seguinte, conforme trata o art. 36 da Lei 4.320/64. Pelo princípio da continuidade dos serviços públicos, as obrigações ainda não pagas transferem-se ao exercício seguinte e oneram, em certa medida, o próximo orçamento. Isto do lado da despesa. No âmbito das receitas, também elas não se costumam comportar como o previsto, podendo ser lançadas, mas não recebidas, em determinado exercício financeiro. Neste caso, são inscritas como dívida ativa (art. 39, Lei 4320/64). Observa-se, assim, a característica flutuante do ambiente orçamentário, submetido às variações conjunturais da realidade econômica e à adaptação da programação administrativa a elas. Neste sentido, o princípio da anualidade também não é compreendido em termos absolutos, mas admite que receitas e despesas de um exercício tenham seus efeitos prolongados em outros. A inclusão dos restos a pagar e da dívida ativa no orçamento, porém, reforça a necessidade de que haja transparência quanto a tais informações, para que se saiba quanto do orçamento de um ano está comprometido pela inexecução do orçamento anterior: a flexibilidade existe aí, como se nota, para preservar o conhecimento e o controle parlamentares sobre a atividade financeira pública. Do contrário, caso o tema da execução fosse assunto restrito exclusivamente ao Poder Executivo, não seria necessário que despesas e receitas já aprovadas num ano fossem novamente conduzidas à apreciação parlamentar. Fosse o orçamento uma autorização conferida, problema algum haveria em seu não cumprimento.

\subsubsection{A especialidade material: aspectos quantitativo e qualitativo}

A partir destas considerações, pode-se definir que, no interesse da especialidade material do orçamento público, as previsões das despesas orçamentárias devem ser, tanto quanto ao tipo como quanto ao montante, observadas pelos órgãos encarregados de executar o orçamento. Qualitativamente, a especialidade significa a definição das finalidades. Quantitativamente, refere-se aos créditos orçamentários, isto é, às verbas estabelecidas para cada programa. 


\subsection{Especialidade qualitativa}

O princípio da especialidade qualitativa do orçamento público, ocasionalmente também referido como princípio da dotação, prescreve que os objetivos definidos pelo orçamento apenas podem receber os recursos a eles alocados. É inadmissível, por conseqüência, que um crédito orçamentário se destine, total ou parcialmente, a despesa não prevista, ou que tenha aplicações em finalidades diferentes daquelas às quais ele foi dotado.

Este princípio tem grande significado tanto em sentido financeiro como político. De nada adiantaria ser o orçamento completo e transparente, estimado com a maior precisão possível, aprovado regularmente e assim por diante, se os órgãos responsáveis por sua execução tivessem toda liberdade de empregar os meios previstos em programas diferentes daqueles aprovados, assim como mover livremente eventuais saldos e economias, ou de transferir sobras de despesas anuladas ou já suficientemente cobertas para outros títulos, como bem lhes aprouvesse. As chances de o orçamento atingir os fins para os quais ele foi aprovado estariam, neste caso, seriamente comprometidas e o rito de aprovação parlamentar não teria qualquer função. Politicamente, o Parlamento não teria influência sobre o orçamento. Sob o ponto de vista financeiro, este processo de sucessivas alterações arbitrárias teria a conseqüência de que o planejamento orçamentário seria substituído pela aleatoriedade e pelo arbítrio.

No que concerne às condições de realização deste princípio, tem-se que ele depende de condições objetivas e subjetivas, conforme exposto por Neumark ${ }^{173}$.

Como condição objetiva, os créditos orçamentários devem ser altamente delimitados. Dado que existe uma estreita conexão entre a especialidade qualitativa e a transparência, esta depende decisivamente do grau de aplicação daquela. Mas isso não significa que, no interesse da transparência, a exclusão de informações demasiadamente minuciosas deva ter até as últimas consequências para a execução orçamentária, ficando os agentes encarregados por ela impossibilitados de realizar os detalhes não previstos. Antes, o princípio significa que se tornam juridicamente vinculantes apenas as partes

173 NEUMARK, F. Der Reichshaushaltplan: ein Beitrag zur Lehre vom öffentlichen Haushalt. Jena: Verlag von Gustav Fischer, 1929, p. 299 e ss. 
dos créditos orçamentários que sejam suficientes para esclarecer, de maneira clara, sua finalidade.

Exigência subjetiva é que o Poder Executivo não se afaste da finalidade dos créditos orçamentários. O cumprimento voluntário desta condição é, na prática, raro, porque cada órgão da burocracia administrativa apresenta a tendência de querer agir tão autonomamente quanto possível ${ }^{174}$. Como as administrações dificilmente têm o poder de aprovar um orçamento apenas com dotações globais ou fundos conjuntos, sistemas de flexibilidade são, em alguns sistemas, pensados para permitir transferências entre programas, abrindo-se uma exceção ao princípio da especificação (tais como os tradicionais virements do direito orçamentário francês).

De qualquer maneira, a especialidade qualitativa apenas tem alguma utilidade prática se sua observação é garantida por instituições de controle. Sem normas e órgãos encarregados de verificar sua aplicação, a chance de que os recursos sejam aplicados da maneira como aprovados é quase nula.

\subsection{Especialidade quantitativa}

De acordo com o princípio da especialidade quantitativa do orçamento, as despesas apenas podem ser realizadas com o montante de recursos previstos para ela. Consequentemente, por este princípio não se admitem despesas nem que extrapolem nem que criem novas dotações orçamentárias. Conforme expressa Fritz Neumark, seria ilógico que esta formulação caracterizasse apenas o último ato do processo de realização da despesa, que é seu pagamento, como ilegítimo, se ela ultrapassasse ou se fizesse por dotação nova. Portanto, estende-se a todos os atos administrativos anteriores pelos quais se processo o dever jurídico de pagamento, tais como o empenho e a liquidação ${ }^{175}$, a seguir expostos.

Ao se abrirem créditos adicionais ao orçamento, sob a modalidade de suplementação ou de criação de novo programa, frequentemente os documentos

\footnotetext{
${ }^{174}$ Cf. item 2.1.5.3.

175 NEUMARK, F. Der Reichshaushaltplan: ein Beitrag zur Lehre vom öffentlichen Haushalt. Jena: Verlag von Gustav Fischer, 1929, p. 311.
} 
governamentais fazem referência a alterações "quantitativas" e "qualitativas", respectivamente. Deste modo, os créditos suplementares seriam alterações quantitativas, ao passo que os especiais seriam qualitativas. Esta diferenciação se baseia na ideia de que, no primeiro caso, somente a especialidade do montante de recursos dotados é afetada, ao passo que, no outro, trata-se de uma alteração na natureza da finalidade definida. Em obra aqui considerada, Neumark que o cerne desta separação conceitual é correto, mas a classificação não parece ser útil. Nos dois casos, será criada uma despesa adicional, representando sempre uma maior carga ao orçamento público ${ }^{176}$. Ocorre que esta não é uma consideração generalizável. Em sistemas jurídico-orçamentários tais como o brasileiro, que especificam não apenas a modalidade de crédito, mas também a origem dos recursos, nem sempre se pode afirmar que as despesas aumentam com a abertura de crédito adicional, pois que em alguns casos os recursos admitidos são aqueles provenientes da anulação de outras despesas. O mais provável é que o caso a que se refere o jurista alemão não seja exatamente aquele enquadrado no conceito de crédito adicional, mas de transferências, remanejamentos e transposições.

Este princípio tem significativa importância para a manutenção das prerrogativas parlamentares de aprovação do orçamento, também dependendo de significativo controle para sua concretização, para controlar as tentações de que sempre padece o Poder Executivo. Em razão disso, as alterações na quantidade dos créditos apenas podem ser feitas em conformidade com o que disciplinem as normas aplicáveis. No sistema brasileiro, há tanto normas constitucionais como legais a respeito. Se as próprias normas constitucionais, porém, estabelecem possibilidades tão largas de flexibilização, como a previsão de uma autorização prévia para aberturas de créditos adicionais em limites não definidos, não é possível esperar que o respeito democrático ao orçamento aprovado seja feito por boa vontade do administrador, quando lhe é dada a legítima possibilidade de lançar mão dos mais diversos expedientes de mudá-lo sem qualquer ameaça de devido contrapeso do Congresso. Neste caso, é de se esperar normas mais restritivas para contornar este quadro.

Uma das alternativas apontadas é que as necessidades impostergáveis de despesas adicionais sejam de alguma forma incorporadas ao orçamento, por exemplo

\footnotetext{
176 NEUMARK, F. Der Reichshaushaltplan: ein Beitrag zur Lehre vom öffentlichen Haushalt. Jena: Verlag von Gustav Fischer, 1929, p. 311.
} 
por meio da previsão de uma reserva de contingência. A finalidade não é apenas política, mas também econômica, pois permite maior comparação entre despesas e receitas. De um lado, é impossível planejar em cada caso concreto uma estimativa orçamentária para despesas imprevistas. Isto seria um grande encargo tanto ao Parlamento como à Administração, sem que se garantissem resultados palpáveis. Em vista destas considerações, as necessidades não previstas no orçamento original e que não podem esperar sua satisfação até o próximo exercício financeiro devem ser estimadas e aprovadas por lei. Para tanto, há principalmente duas alternativas à disposição de um sistema jurídico orçamentário, que são: a revisão completa do orçamento público no decorrer do exercício financeiro; ou alterações específicas, feitas caso a caso. À primeira denomina-se comumente orçamento retificativo; as outras correspondem aos créditos adicionais. Ambos são meios juridicamente legítimos na medida em que previstos pelas normas jurídicas de um dado sistema.

\subsection{A execução do orçamento brasileiro: do registro dos créditos ao pagamento}

Será feita, neste ponto, uma descrição das formas jurídicas mais relevantes para os procedimentos administrativos da execução da despesa pública, dando-se destaque para algumas etapas anteriores, referentes à especificação dos créditos orçamentários. A finalidade é estabelecer a relação prevista nas normas jurídicas entre a execução da despesa e o crédito que a prevê, assim como o caráter especial dos instrumentos de flexibilidade, que devem vir a ser adotados diante de circunstâncias específicas, e não pode, pois, ser vista como uma prerrogativa geral dos órgãos responsáveis pela execução.

\subsubsection{O orçamento analítico como expressão da especialidade orçamentária}

A expressão "orçamento analítico" costuma ser usada, no Brasil, para se referir à maneira de inclusão das receitas e despesas no orçamento e a seu grau de especialidade. Abrange, portanto, este princípio, embora não distinga, claramente, entre seus aspectos qualitativo e quantitativo acima apontados. Sob o ponto de vista jurídico, falar em orçamento analítico significa fazer referência às normas que determinam o 
detalhamento e a extensão do orçamento, conforme a legislação específica que discipline a matéria em cada unidade da Federação. A especificação e o modo de sua organização contábil são fundamentais para a execução, determinando o modo de seu exercício. Normalmente, também, diz respeito a quadros que discriminam, o quanto for possível e conveniente, a classificação das despesas e das receitas. Representada no art. $5^{\circ}$ da Lei 4.320/64, que repugna as despesas globais, esta ideia traduz, no sistema orçamentário brasileiro, ora a previsão de que as dotações se destinem apenas à finalidade para a qual foram previstas (aspecto qualitativo), ora a que apenas sejam executadas nos montantes autorizados (aspecto quantitativo). Embora não seja feita esta discriminação, o objetivo é inequívoco: que haja condições ideais de fiscalização pelo Parlamento, além do fato de que esta especificação inibe que as atividades governamentais se expandam muito além dos créditos detalhadamente aprovado ${ }^{177}$. O problema mais sério, já diagnosticou José Afonso da Silva ${ }^{178}$, é

saber qual o limite da discriminação, pois não deverá haver descrição minuciosa nem globalização. Na técnica do orçamento-programa, a especialização se traduz, em primeiro lugar, na classificação dos recursos e das despesas, e, depois, dentro de cada classe é que se realiza a discriminação.

Neste ponto, é relevante destacar a ressalva preocupação com uma especificação paralisante da execução orçamentária na doutrina orçamentária brasileira, apontada no excerto acima e desenvolvida por Giacomoni ${ }^{179}$ :

não cabe transformar as unidades executoras em reféns de uma programação orçamentária excessivamente detalhada, especialmente quando a retificação desta programação depende de demorados procedimentos burocráticos e legais.

A especialização se traduz, no orçamento-programa, pela classificação de receitas e das despesas, e estes são discriminados dentro de cada classe. $\mathrm{O}$ art. 11 da Lei 4.320/64 determina a classificação de receitas em correntes e de capital e o art. 12 o faz quanto às despesas, também classificadas em despesas correntes (despesas de custeio e transferências correntes) e despesas de capital (investimentos, inversões financeiras e transferências de capital). Cada um desses itens que constituem a respectiva classe encontra sua definição na legislação. Estas são as chamadas categorias econômicas de classificação. Dentro de cada uma dessas categorias é feita a discriminação da despesa

\footnotetext{
177 GIACOMONI, J. Orçamento Público. 13ª ed. São Paulo: Atlas, 2005, p. 82.

${ }^{178}$ SILVA, José Afonso da. Orçamento Programa no Brasil. São Paulo: RT, 1973, p. 255.

${ }^{179}$ GIACOMONI, J. Orçamento Público. $13^{\mathrm{a}}$ ed. São Paulo: Atlas, 2005, p. 263-4.
} 
"por elementos, em cada unidade administrativa ou órgão de Governo" (art. 13, Lei 4.320/64), conforme o extenso esquema delineado neste dispositivo. De acordo com o art. 15 da mesma lei, a discriminação deve ser feita, no mínimo, por elementos, admitindo-se, porém, especificações mais minuciosas.

Cumpre ressaltar que a classificação de receitas e despesas em categorias econômicas (correntes e de capital) não basta para que se atenda ao princípio da especificação, devendo-se discriminá-las dentro das instituições, no nível global das diversas categorias orçamentárias (Programa, Subprograma, Atividade, Projeto e Obra) e, em muitos casos, segundo uma distribuição geográfica ou regional.

Dizendo de maneira ampla, o conhecimento dos resultados da gestão patrimonial depende da classificação das contas. A classificação contribui à efetiva execução do orçamento, facilita a formulação de programas e a prestação de contas e torna possível a análise dos efeitos econômicos das atividades governamentais.

\subsubsection{Registro dos créditos e dotações}

O modelo analítico de orçamento se opera por meio registro dos créditos orçamentários e das dotações, para que se possa acompanhar o andamento de seus

saldos e, mais amplamente, da programação do governo. ${ }^{180}$ Aqui, também a disciplina do registro serve tanto a fins quantitativos (pois permite conhecer a classificação e o título apropriado em que cada despesa deve ser lançada) como qualitativos (com a possibilidade de que os montantes de cada uma das dotações fiquem evidenciados).

Como ressalva prévia ao tema, aponta-se uma comum confusão terminológica entre créditos orçamentários e dotações. Giacomoni ${ }^{181}$ e Machado Jr. e Heraldo Reis ${ }^{182}$ distinguem-nos, dizendo que dotação "deve ser a medida, ou quantificação monetária do recurso aportado a um programa, atividade, projeto, categoria econômica ou objeto de

\footnotetext{
${ }^{180}$ Cf. GIACOMONI, J. Orçamento Público. 13 $3^{\mathrm{a}}$ ed. São Paulo: Atlas, 2005, p. 265.

${ }^{181}$ GIACOMONI, J. Orçamento Público. 13a ed. São Paulo: Atlas, 2005, p. 265.

182 MACHADO Jr., José Teixeira; REIS, Heraldo da Costa. A Lei 4.320 comentada e a lei de responsabilidade fiscal. $31^{\mathrm{a}}$ ed. Rio de Janeiro: IBAM, 2002/2003, p. 20.
} 
despesa"183. O crédito orçamentário é "a autorização através da lei de orçamento ou de créditos adicionais para a execução de programa, projeto ou atividade ou para o desembolso de quantia aportada a objeto de despesa, vinculado a uma categoria econômica, e, pois, a um programa". Portanto, o crédito orçamentário contém uma dotação, em relação de continente e conteúdo.

A Lei 4.320/64 apresenta as seguintes categorias classificatórias que constituem o crédito orçamentário: Elemento, Subcategoria Econômica, Categoria Econômica, Projeto ou Atividade, Subprograma, Programa, Função, Unidade Orçamentária e Órgão. Dada a relevância da concepção de orçamento-programa para o sistema orçamentário vigente, convém destacar a incorporação, pela referida lei complementar, por meio de seu Anexo $\mathrm{n}^{\circ} 5$, da classificação funcional-programática, que já havia sido adotada pelo orçamento federal a partir de 1968. Esta classificação é o antecedente da classificação por programas, adotada nos orçamentos federais a partir de 1999. Absorvida pela lei complementar, a classificação funcional-programática valeu como norma geral que se deve aplicar aos orçamentos das diversas entidades federativas. São cinco as categorias por ela escorçadas: função, programa, subprograma, projeto e atividade, em ordem crescente de especialidade. A Portaria $n^{\circ}$ 9/74 (que acabou transformada no citado Anexo 5) define projeto e atividade. Projeto é o "instrumento de programação para alcançar os objetivos de um programa, envolvendo um conjunto de operações limitadas no tempo, das quais resulta um produto final que concorre para a expansão ou o aperfeiçoamento da ação do governo." De outro lado, a atividade é "um instrumento de programação para alcançar os objetivos de um programa, envolvendo um conjunto de operações que se realizam de modo contínuo e permanente, necessárias à manutenção da ação do governo". Daí se entende que, se o programa, que compreende projetos, atividades e operações especiais, é o objetivo a se atingir com a execução do orçamento, acaba sendo ele também definido como a categoria mais importante. Além disso, “funções são, então, constituídas pela divisão, em grandes linhas, das áreas de atuação do governo. Os subprogramas são partes dos programas; representam objetivos parciais buscados pelo governo por meio do orçamento" ${ }^{184}$.

\footnotetext{
183 MACHADO Jr., José Teixeira; REIS, Heraldo da Costa. A Lei 4.320 comentada e a lei de responsabilidade fiscal. $31^{\text {a }}$ ed. Rio de Janeiro: IBAM, 2002/2003, p. 20.

${ }^{184}$ GIACOMONI, J. Orçamento Público. 13 ${ }^{\mathrm{a}}$ ed. São Paulo: Atlas, 2005, p. 100.
} 
A partir desta orientação normativa, adotou-se a classificação por programas, que tem o objetivo de vincular as despesas aos resultados pretendidos. Esta classificação é exigência legal no Brasil desde que a Lei 4.320 determinou que a lei orçamentária “conterá a discriminação da receita e despesa, de forma a evidenciar a política econômico-financeira e o programa de trabalho do Governo" $\left(\operatorname{art.} 2^{\circ}\right.$ ), ainda que tenha levado certo tempo para sua efetivação mais aperfeiçoada.

A partir de 1990, conforme determinação da Lei de Diretrizes Orçamentárias então vigente, alterou-se a noção de classificação conforme a natureza da despesa, que envolvia a obrigatoriedade de discriminar a despesa até o nível de elementos. Tal determinação foi estendida a outras unidades da federação a partir do exercício de 2002, por meio de Portaria Interministerial, que pôde introduzir tal norma geral a partir do disposto no art. $50, \S 2^{\circ}$, da Lei Complementar 101/2000 ${ }^{185}$. Mantiveram-se as categorias econômicas E criaram-se grupos de despesa e o conceito de modalidade de aplicação. O art. $6^{\circ}$ da Portaria Interministerial STN/SOF 163/2001, entretanto, permitiu excluir o item "elementos" da lei orçamentária, dispondo que, nela, a discriminação da despesa será feita, quanto à sua natureza, no mínimo, por categoria econômica, grupo de natureza de despesa e modalidade de aplicação. Trata-se de norma cujo teor é claramente contrário ao art. 15 da Lei 4.320/64, que prevê a classificação da despesa, segundo sua natureza, no mínimo por elementos. Como esta é uma lei complementar, não é possível que seja alterada por portaria, mesmo que se trate do exercício de competência prevista pelo art. 50, $§ 2^{\circ}$, da LRF.

Este dispositivo da lei 4.320/64, embora ainda válido e não revogado por ato de hierarquia inferior, é um ponto crítico da lei geral do orçamento, exatamente por sua rigidez. Com um sistema classificatório que esmiúça a despesa no orçamento até o nível dos elementos, ficam estes indissociáveis da subcategoria econômica, item mais abrangente no qual se incluem, podendo-se vislumbrar dificuldades quanto à discriminação adequada na elaboração e no acompanhamento da execução orçamentária.

\footnotetext{
${ }^{185}$ Este artigo dispõe que "a edição de normas gerais para consolidação das contas públicas caberá ao órgão central de contabilidade da União, enquanto não implantado o conselho de que trata o art. 67". A STN exerce a competência temporária de "órgão central de contabilidade da União".
} 
A Portaria Interministerial STN/SOF 163/2001, modificada por sucessivas portarias, teve a finalidade de resolver dificuldades como estas, combinando categorias econômicas, grupos, modalidades de aplicação e elementos. Permitiu que estes últimos estivessem presentes em diversos grupos. Um problema, porém, permanece: despesas com pessoal devem ainda ser classificadas como Pessoal e Encargos Sociais, vinculando-se necessariamente às Despesas Correntes.

Relacionando o registro dos créditos com a ideia de orçamento analítico, ambos expressões do princípio da especificidade, o detalhamento orçamentário se costumava realizar por meio do Quadro de Detalhamento de Despesa (QDD), que cada Poder e o Ministério Público elaboravam no seu respectivo âmbito de atuação. Feita a citada reorganização da classificação da despesa conforme a natureza, adotando-se as categorias econômicas, grupo, modalidade de aplicação e elemento, apenas os grupos de despesa constavam da lei orçamentária. As demais vinham no QDD, o que conferia ao Executivo grande poder de disposição sobre os créditos orçamentários, já que a aprovação do orçamento pelo Congresso se dava em termos mais genéricos e era o Governo que elaborava o quadro de detalhamento. Por emendas à Lei 9.692/1998 (Lei de Diretrizes Orçamentárias para o exercício de 1999), o Congresso Nacional determinou que apenas a categoria "elementos" não constasse da lei orçamentária. Todas as outras devendo estar ali referidas. Há, assim, maior transparência na Lei Orçamentária, ainda que o Poder Executivo possa, por atos internos, promover alterações nas categorias.

Por outro lado, e antes da alteração citada acima, o QDD já apresentara certos inconvenientes ao Poder Executivo, que o alterou em alguns aspectos. Os inconvenientes alegados se resumem à falta de agilidade da execução da despesa quando se tem que elaborar e publicar constantemente o QDD, além de ser necessário fazer constar nele as alterações da classificação verificadas durante o exercício. Tentando afastar tais empecilhos, a LDO para o exercício de 1997 (Lei 9.293/96, art. 56, caput, e art. $3^{\circ}$ ) determina que apenas o QDD inicial seja publicado. As alterações necessárias devem ser feitas diretamente no Sistema Integrado de Administração Financeira (SIAFI), em que ocorre o procedimento de detalhamento do Orçamento.

Revela-se, por isso, que o registro dos créditos orçamentários, ainda que deva atender ao princípio da especificidade, classificando a despesa em diversas categorias e 
níveis de detalhamento, depara-se com certo grau de maleabilidade da classificação. É evidente, entretanto, que a necessidade de flexibilidade na fase de execução do orçamento se deve coadunar com o princípio da legalidade, bem como do controle parlamentar. O orçamento se sujeita à apreciação do Congresso Nacional, a quem obviamente não incumbe apenas a aprovação de créditos globais. Os créditos devem ser tão específicos quanto o possam. Por outro lado, não tão específicos a ponto de não admitir qualquer alteração. Le Gouvernment doit être lié mais non ligoté ${ }^{186}$. Neste sentido, a iniciativa do SIAFI é adequada por permitir que na lei orçamentária conste classificação suficiente, de maneira que chegue à cognição parlamentar o conteúdo correto da despesa apreciada, e, ao mesmo tempo, por possibilitar que detalhamentos maiores, no patamar de elementos, sub-elementos e itens, dispensáveis de tomar grande tempo do processo político de aprovação do orçamento, sejam feitos diretamente num sistema ágil e, afinal, de toda forma transparente e aberto ao controle.

\subsubsection{Programação financeira e cronograma de desembolso}

A previsão orçamentária das receitas e despesas, de acordo com o princípio da anterioridade, não tem por consequência que a execução das operações de arrecadação e dispêndio fique submetida a uma obrigação de conformidade absoluta, o que seria impossível. Esta obrigação é mais restritiva quanto às receitas, mas não por força da previsão orçamentária, já que há muito não vige o princípio da anualidade tributária, e, sim, por decorrência do princípio da legalidade: o ato de arrecadação que não encontre seu fundamento em norma válida é reputado nulo. Além disso, como a instituição de tributo é matéria de competência legislativa, a administração não pode, no momento da execução, modificar a lei tributária ou apreciar a conveniência e a oportunidade da arrecadação, pelo que o tributo, conforme a dicção do art. $3^{\circ}$ do Código Tributário Nacional, é cobrado mediante atividade administrativa plenamente vinculada. No que concerne não ao tipo, mas ao montante da previsão do tributo, o orçamento fornece uma estimativa. Neste ponto, a autorização orçamentária é ainda menos constritiva, porque é uma autorização ilimitada: o Estado pode arrecadar mais do que o volume previsto, desde que exerça suas competências nos termos das normas em vigor.

\footnotetext{
${ }^{186}$ GAUDEMET, P.-M.; MOLINIER, J. Finances Publiques. $7^{\mathrm{a}}$ ed. Paris: Montchrestien, 1996. v. 1, p.
} 100 . 
Em relação à estrita obrigação de execução que prevalece quanto às receitas, a qual, repita-se, não decorre da previsão orçamentária, mas de outras normas jurídicas, a execução da despesa tem uma margem de apreciação significativamente maior. A lei orçamentária institui faculdades de utilização de créditos, estabelecendo limites máximos nas suas dotações, visto que a Constituição proíbe a concessão de créditos ilimitados (art. 167, inciso VII). A inscrição de créditos na lei orçamentária é uma condição necessária para que a despesa seja regularmente executada, mas como já se mencionou que o orçamento não opera no vácuo, é necessário relacionar a despesa à arrecadação.

Especificadas as despesas que deverão ser executadas no exercício financeiro posterior àquele de sua inclusão na proposta orçamentária, a Administração se depara, porém, com outra questão essencial para a adequada gestão dos recursos: o ritmo em que estes deverão ser pagos. O planejamento do tempo de liberação do dinheiro público é instrumentalizado pela programação financeira e pelo cronograma do desembolso, que será estabelecida pelo Poder Executivo, nos termos do art. $8^{\circ}$ da Lei Complementar 101/2000, após 30 dias da publicação dos orçamentos, de acordo com o que disponha a LDO. Trata-se de disposição paralela às quotas trimestrais da despesa previstas pela regra anterior, contida nos arts. 47 a 50 da Lei 4.320/64. O Decreto-Lei 200/67, no art. $7^{\circ}, d$, trata a programação financeira do desembolso como instrumento básico do planejamento da ação governamental.

Esta programação tem a função de "ajustar o ritmo de execução do orçamentoprograma ao fluxo provável de recursos", de maneira a "assegurar a liberação automática e oportuna dos recursos necessários à execução dos programas anuais de trabalho" (art. 17, Dec.-Lei 200/67). Somente em consonância com a programação financeira do desembolso é que compromissos financeiros poderão ser assumidos (art. 18 , idem).

Em linhas gerais, a programação de desembolso existe porque a entrada de receitas e o pagamento das despesas não ocorrem nem ao mesmo tempo, nem no volume necessário para as diferentes ocasiões. Cabe ao governo planejar seus gastos de acordo com o fluxo dos recursos que ingressam em sua contabilidade. É um importante instrumento de racionalização da liberação dos recursos às unidades orçamentárias 
necessários à execução de seus programas de trabalho. Esta programação se caracteriza por três objetivos fundamentais:

\begin{abstract}
ajustar o ritmo de execução do orçamento ao fluxo provável de recursos, assegurar a entrega automática às unidades orçamentárias, em tempo hábil e dentro dos limites previamente estabelecidos, da soma de recursos financeiros necessários e suficientes à execução dos seus programas, e manter, durante o exercício, na medida do possível, o equilíbrio entre a receita e a despesa realizada, de modo a reduzir ao mínimo eventuais insuficiências de tesouraria ${ }^{187}$.
\end{abstract}

O desembolso de dinheiro público necessário à execução de programas deve ocorrer de forma a considerar o fluxo das receitas. Cabe ao Poder Executivo elaborar o cronograma mensal de desembolsos (art. 8º, LC 101/2000), incluindo, na fixação das quotas mensais, também os créditos adicionais e as operações extra-orçamentárias, particularmente os restos a pagar (art. 49, Lei 4.320/64). Com este dispositivo de inclusão na programação de outras operações de natureza financeira,procurou-se disciplinar o fluxo de caixa tomando em consideração

as disponibilidades existentes; a afluência provável da receita própria e de receitas transferidas; o orçamento aprovado, com a discriminação por unidades orçamentárias; outros débitos ou compromissos, como os oriundos de créditos especiais abertos nos últimos quatro meses do exercício recémencerrado; os restos a pagar; os compromissos da dívida pública e outros dessa natureza; e outros compromissos e circunstâncias que possam influir no comportamento efetivo das receitas e na realização da despesa" ${ }^{188}$.

Com esta extensão se refere o dispositivo legal aos créditos adicionais e operações extra-orçamentárias.

É ínsita a este dispositivo legal a ideia de que a programação é um processo contínuo da Administração. Feita a programação inicial no Orçamento, que é aprovada como determinado plano de trabalho, ela deve começar a ser executada também de forma planejada. Para evitar que a Administração atue de modo a concentrar todas as despesas nos primeiros meses do ano, quando a tesouraria arrecadou apenas pequena parte dos recursos, adotava-se anteriormente o regime dos duodécimos como medida central para planejar o ritmo da execução, pelo qual a despesa era dividida em doze partes iguais, correspondentes a cada mês do ano. Em cada período mensal se poderia utilizar $1 / 12$ da dotação prevista. Distribuía-se a despesa ao longo do ano. É o modo de

\footnotetext{
${ }^{187}$ SILVA, José Afonso da. Orçamento Programa no Brasil. São Paulo: RT, 1973.

188 MACHADO Jr., José Teixeira; REIS, Heraldo da Costa. A Lei 4.320 comentada e a lei de responsabilidade fiscal. $31^{\text {a }}$ ed. Rio de Janeiro: IBAM, 2002/2003, p. 126.
} 
execução atualmente vigente, por exemplo, em Portugal ${ }^{189}$. Este tipo de programação, todavia, é problemático por estabelecer limites mensais para a execução do programa da Administração: o sistema funciona bem com relação às despesas fixas, notadamente de pessoal, mas é inoportuno para, por exemplo, a compra de materiais ou outra despesas que não se executam de forma uniformemente distribuída no tempo ${ }^{190}$. É mais adequado que as cotas mensais sejam estabelecidas conforme um programa, atendendo-se à peculiaridade de cada tipo de despesa.

$\mathrm{O}$ art. 13 da LRF prescreve, ainda, que no prazo de 30 dias após a publicação dos Orçamentos, as receitas previstas serão desdobradas, pelo Poder Executivo, em metas bimestrais de arrecadação, com a especificação, em separado e quando cabível, das medidas de combate a sonegação e à evasão, da quantidade e valores de ações ajuizadas para cobrança da dívida ativa, bem como da evolução do montante dos créditos tributários passíveis de cobrança administrativa.

Em suma, a programação é flexível. Pode ser alterada durante o exercício financeiro, o que, demais, se prevê no art. 50 da Lei 4.320/64. As cotas mensais poderão ser alteradas durante o exercício, desde que observados o limite da dotação e o comportamento da execução orçamentária. De modo a contornar os problemas do rígido sistema dos duodécimos, preparou-se, então, um sistema flexível de execução apto a atender às circunstâncias reais que se apresentem conforme o desenvolvimento da relação entre receita e despesa.

Vê-se que as cotas de desembolso são fixadas conforme evolua a arrecadação de receitas, o que é elemento variável. É necessário que exista a possibilidade, então, de alterar a programação financeira estabelecida, como menciona José Afonso da Silva ${ }^{191}$. E não é apenas o comportamento da entrada de recursos que pode justificar a alteração da programação, senão, também, as modificações nas prioridades que a Administração julgue adequado fazer, conforme novas necessidades surjam, em nome do interesse público ${ }^{192}$. Ademais, o art. $9^{\circ}$ da Lei de Responsabilidade Fiscal dá comandos para a revisão da programação do desembolso, que deve ocorrer: no caso de restabelecimento

\footnotetext{
189 RIBEIRO, José Joaquim Teixeira. Lições de Finanças Públicas. $5^{\mathrm{a}}$ ed. Coimbra: Coimbra Editora, 1997, p. 117.

${ }^{190}$ Cf. MACHADO Jr., José Teixeira; REIS, Heraldo da Costa. A Lei 4.320 comentada e a lei de responsabilidade fiscal. 31 a ed. Rio de Janeiro: IBAM, 2002/2003, p. 122.

${ }^{191}$ SILVA, José Afonso da. Orçamento Programa no Brasil. São Paulo: RT, 1973, p. 328.

192 SILVA, José Afonso da. Orçamento Programa no Brasil. São Paulo: RT, 1973, p. 265.
} 
da receita prevista, ainda que parcial, recompondo-se as dotações cujos empenhos foram limitados de forma proporcional às reduções efetivadas; e ao final do bimestre, se for verificado que a realização da receita poderá não comportar o cumprimento das metas de resultado primário ou nominal estabelecidas no Anexo de Metas Fiscais. Neste caso, os Poderes do Estado e o Ministério Público promoverão por ato próprio e nos montantes necessários, nos 30 dias subseqüentes, limitação de empenho e movimentação de receita (o chamado contingenciamento de recursos), segundo critérios fixados pela LDO.

\subsubsection{Estágios da despesa: empenho, liquidação e pagamento}

Definido o empenho no art. 58 da Lei 4.320/64 como o ato emanado de autoridade competente que cria para o Estado obrigação de pagamento pendente ou não de implemento de condição, há algumas outras funções por ele cumpridas no controle da execução do orçamento. Trata-se do ato administrativo ao qual cabe enquadrar a despesa em determinado crédito orçamentário, deduzindo-a. Funciona, além disso, como uma garantia ao credor de que os valores empenhados têm respaldo orçamentário. 193

Como ato cuja finalidade principal é reservar recursos para posterior pagamento, o empenho se mostra uma das etapas mais importantes pela qual passa a despesa pública. Ele evita que o pagamento seja frustrado por falta de verba, e ao mesmo tempo possibilita aos diversos órgãos do Governo conhecer as diversas parcelas empenhadas da despesa. Ressalte-se, todavia, que a prática administrativa brasileira muitas vezes adota o empenho a posteriori, apenas a pretexto de se cumprir formalmente a legislação pertinente. Trata-se de um problema de planejamento e de deficiências de programação. $^{194}$

Por outro lado, o art. 68 estabelece o chamado regime de adiantamento, ao qual o art. 65 já se referira como aplicável a casos excepcionais. Conforme o art. 68, o

\footnotetext{
${ }^{193}$ GIACOMONI, J. Orçamento Público. 13ª ed. São Paulo: Atlas, 2005, p. 270.

${ }^{194}$ MACHADO Jr., José Teixeira; REIS, Heraldo da Costa. A Lei 4.320 comentada e a lei de responsabilidade fiscal. $31^{\mathrm{a}}$ ed. Rio de Janeiro: IBAM, 2002/2003, p. 144.
} 
regime de adiantamento é aplicável aos casos expressamente definidos em lei e consiste na entrega de numerário a servidor, sempre precedida de empenho na dotação própria, para o fim de realizar despesas que não possam subordinar-se ao processo normal de aplicação. Há casos em que os recursos destinados a determinada despesa são empenhados antes que a própria despesa seja pactuada, desde que haja previsão expressa em lei. A previsão deste regime em caráter de exceção confirma, porém, a necessidade de empenho ex ante, mesmo em casos de despesas especiais.

Processado o empenho, segue-se à liquidação. De acordo com o art. 63 da lei 4.320/64, a liquidação consiste na verificação do direito adquirido pelo credor, tendo por base os títulos e documentos comprobatórios do respectivo crédito. É a verificação de que a despesa anteriormente empenhada é legítima, com a finalidade de apurar a origem e o objeto do que se deve pagar, a importância exata e a quem se deve pagar a importância, para extinguir a obrigação (art. 63, § $1^{\circ}$, incisos I, II e III).

Se a liquidação é ato de verificação do direito adquirido pelo credor ao recebimento da prestação, não se pode falar, ainda, que é com este ato que se cria à Administração a obrigação de pagar. As cláusulas contratuais devem ter se verificado cumpridas ${ }^{195}$. Por este motivo, contratos de obras e de prestação de serviços em que se estipula o adiantamento de pagamentos devem ser feitos com cuidado, de modo a evitar que a obra ou o serviço sejam implementados fora das condições exigidas ou que, simplesmente, não sejam realizados de modo algum.

Deve-se considerar sobre a liquidação, também, que não é simplesmente ato formal de verificação do direito adquirido pelo credor, mas deve refletir o que se verificar na realidade, como bem expresso por Machado Jr.:

[h]á um ponto central a considerar: é [a liquidação] a verificação objetiva do
cumprimento contratual. A fase de liquidação deve comportar a verificação
in loco do cumprimento da obrigação por parte do contratante. Foi a obra, por
exemplo, construída dentro das especificações contratadas? Foi o material
entregue dentro das especificações estabelecidas no edital de concorrência ou
de outra forma de licitação? Foi o serviço executado dentro das
especificações? O móvel entregue corresponde ao pedido? E assim por
diante. Trata-se de uma espécie de auditoria de obras e serviços, a fim de

${ }^{195}$ SILVA, José Afonso. Orçamento Programa no Brasil. São Paulo: RT, 1973, p. 342. 
evitar obras e serviços fantasmas. (...) O documento de liquidação, portanto, deve refletir uma realidade objetiva. ${ }^{196}$

Desta feita, as condições previstas na licitação, no contrato, no empenho ou em outro ato administrativo fundamental da relação jurídica em questão, devem restar observadas.

Verificado, pela liquidação, o direito adquirido pelo credor, a autoridade competente exara, por despacho, a ordem de pagamento. Por este determina-se que a despesa seja paga (art.64, Lei 4.320/64). Apenas documentos processados pelos serviços de contabilidade podem exarar a ordem de pagamento (parágrafo unido do art. $64)$.

A execução da despesa encerra-se com o pagamento. Este só será efetuado quando ordenado após sua regular liquidação (art. 62, Lei 4.320/64). O ar. 74 do Decreto-Lei 200 estabelece que o pagamento se fará mediante ordem bancária ou cheque nominativo contabilizado pelo órgão competente, e obrigatoriamente assinado pelo ordenador da despesa e pelo encarregado do setor financeiro. Este dispositivo legal derroga, assim, o art. 65 da Lei 4.320/64, que estabelecia ser efetuado o pagamento por tesouraria ou pagadoria regularmente instituídas, por estabelecimentos bancários credenciados e, em casos excepcionais, por meio de adiantamento.

\subsection{Conclusões parciais}

A aparente aridez com que se apresenta a contabilidade pública no que toca o registro dos créditos e dotações, como desdobramento técnico do princípio da legalidade, não deve obscurecer uma preocupação de índole político-constitucional: se há alguma incompatibilidade entre o cumprimento do orçamento votado pelo parlamento e a necessidade de sua adaptação às circunstâncias que se apresentem no momento da execução, ela é aparente. Os objetivos de eficiência da execução não podem ser compreendidos como uma etapa extra-normativa ou alheia à legalidade do ciclo orçamentário. Com o perdão do truísmo, executa-se o orçamento para cumprir o

\footnotetext{
196 MACHADO Jr., José Teixeira; REIS, Heraldo da Costa. A Lei 4.320 comentada e a lei de responsabilidade fiscal. $31^{\mathrm{a}}$ ed. Rio de Janeiro: IBAM, 2002/2003, p. 149-150.
} 
orçamento. Da mesma forma, muda-se o orçamento para que se torne possível cumprir seus objetivos.

De certa forma, a classificação das despesas apenas até um ponto em que não comprometa a eficiência administrativa, evitando previsões detalhadíssimas e tolhedoras da discricionariedade administrativa, mostra que o orçamento público já concede ao Poder Executivo margem para promover a adaptação do orçamento às necessidades mais específicas da Administração. Contudo, ajustes maiores, que atinjam níveis mais amplos da classificação da despesa, devem retornar à apreciação parlamentar - o que já é feito, na fase de execução, pela submissão de propostas de lei que criam créditos adicionais ou transferem recursos de uma dotação para outra.

Nota-se a preocupação da ordem jurídica com a manutenção de certo grau de flexibilidade também nas fases técnicas de execução da despesa, em que se procura ajustar o ritmo do empenho à existência de recursos suficientes. O contraste entre empenho e dotação orçamentária já mostra, por si, que o sistema orçamentário reconhece a necessidade de cumprimento do orçamento aprovado, por meio da obediência ao que foi ali especificado. Esta é a lógica que deve presidir o regime de execução da despesa. A programação financeira e o cronograma do desembolso destinam-se a objetivos específicos: ajustar o ritmo da execução à conjuntura. De modo algum é um instrumento de planejamento descolado do sistema orçamentário, com prerrogativas autônomas à decisão parlamentar.

Se é possível identificar na flexibilidade da execução orçamentária o objetivo de permitir a realização dos programas orçamentários por meio de indispensáveis adaptações que surjam do ambiente econômico e social, é também possível supor que os instrumentos de flexibilização devam atender a tais objetivos. E caso surja necessidade de novo programa, não previsto, que se siga o processo legislativo. Há alguns meios de alteração dos créditos orçamentários, todavia, que parecem fugir a esta orientação. 


\section{A HETEROGENEIDADE DOS INSTRUMENTOS DE FLEXIBILIDADE ORÇAMENTÁRIA}

Se o propósito específico deste trabalho é identificar dessemelhanças de racionalidades entre os instrumentos de flexibilidade da execução orçamentária, convém iniciar sua análise jurídica a partir de uma distinção que leva em conta o grau de participação do Poder Legislativo em sua aprovação. Há, assim, instrumentos de flexibilidade em que a intensidade da participação parlamentar é, potencialmente:

a) forte: créditos suplementares que ultrapassam os limites de autorização prévia da lei orçamentária; créditos especiais; transferências, transposições e remanejamentos;

b) fraca: créditos suplementares abertos dentro dos limites de autorização prévia da lei orçamentária; créditos extraordinários; e

c) fraquíssima: limitação de empenho e movimentação financeira.

Chama-se aqui de forte a aprovação de medidas de flexibilização da execução que dependem de aprovação prévia e específica do Poder Legislativo. De outra parte, pode ser considerada fraca se esta aprovação ou não é prévia, como no caso dos créditos extraordinários, ou não é específica, como no caso dos créditos suplementares cuja abertura é previamente autorizada pela lei orçamentária anual. Há, ainda, os instrumentos de flexibilidade em que não há, ainda que pudesse haver, participação parlamentar, como na limitação de empenho e movimentação financeira. ${ }^{197}$

Se a execução orçamentária tem por finalidade cumprir os objetivos da lei orçamentária aprovada pelo Poder Legislativo, seria de se supor que a utilização de instrumentos de flexibilidade por parte do Poder Executivo tivesse igualmente que se submeter, por paralelismo, à aprovação do Parlamento. Há casos, conforme exposto nesta classificação, que escapam a tais fundamentos da execução orçamentária, com insuficiente controle parlamentar. Estes instrumentos serão caracterizados a seguir.

\footnotetext{
197 Optou-se, aqui, pela denominação que a legislação dá a cada uma destes casos, ainda que o uso do jargão político ou jornalístico pudesse facilitar a compreensão. Estes termos, porém, serão introduzidos nos itens respectivos.
} 


\subsection{Controle parlamentar forte}

Conforme exposto acima, o tópico exporá os mecanismos de aprovação de algumas modalidades de créditos adicionais, bem como alguns outros instrumentos de menor relevância. Sob um mesmo gênero de créditos adicionais, portanto, se encontram formas variadas de exercício de controle parlamentar. As considerações inicialmente feitas sobre créditos adicionais não devem, deste modo, implicar que haja alguma uniformidade entre tais créditos. Será procedida unicamente com o propósito de delimitar melhor suas espécies para partir às distinções necessárias.

\subsubsection{Créditos adicionais suplementares e especiais}

Uma das alternativas possíveis para modificar o orçamento seria alterá-lo em bloco, no curso do próprio exercício financeiro. Tais orçamentos retificativos são instrumentos adicionais à realização da transparência. Esta vantagem, entretanto, é acompanhada de outras desvantagens que surgem principalmente do fato de que a elaboração de um orçamento retificativo no curso da execução orçamentária faz com que o orçamento original não seja levado tão a sério nem pelo Executivo nem pelo Legislativo. $O$ governo, ao apresentar o projeto de orçamento, sente-se livre da pressão de realizar estimativas precisas, contando com a possibilidade de realizar as correções posteriormente, e o corpo legislativo encarregado de aprová-lo dedicará à atividade de apreciação da proposta apenas uma atenção superficial.

Se os orçamentos retificativos, a princípio, servem para garantir o princípio da especialidade quantitativa do orçamento, assim como o fazem os créditos adicionais regularmente aprovados, e se têm a virtude de não afetar a unidade e a transparência orçamentárias, grande parte dos Estados decidiram evitar os efeitos negativos de leis orçamentárias de retificação. Para isso, é comum que os Estados que adotam este sistema façam com que o orçamento retificativo substitua o orçamento inicial não in toto, mas apenas o complete.

Tais orçamentos retificativos não estão previstos no Brasil, que preferiu adotar um sistema de alterações específicas, principalmente por meio de créditos adicionais. 
Em muitos casos, porém, a distinção não é tão clara, visto que um mesmo ato normativo de abertura de crédito adicional contém alterações de inúmeras dotações orçamentárias.

As referências históricas aos créditos adicionais não são elogiosas. Frequentemente foram apontados como os piores inimigos do equilíbrio orçamentário, em razão do abuso em sua utilização. A legislação do Império procurou sempre reduzir a competência do Executivo em seu uso e houve ministros que aconselharam sua extinção - e foram por isso elogiados como ministros que "desarmaram a si próprios". 198

Foi a Lei de 9 de setembro de 1850 a primeira a regular o uso de créditos adicionais. Antes deste diploma, sua abertura não era autorizada sequer no caso de ausência de Parlamento. A prática, contudo, destoava da previsão jurídica. Para o exercício de 1828, o governo pediu suplementação de despesas destinadas à Corte do Rio de Janeiro (o único orçamento que havia sido votado pelo Parlamento até 1830) e sofreu, por isso, forte oposição entre os políticos e juristas da época, pois esta seria medida "capaz de inutilizar o orçamento, a principal arma do povo contra os excessos do poder"199. O art. $4^{\circ}$ da lei regulamentadora dispunha, então, que os créditos suplementares poderiam ser abertos apenas para atender a despesas variáveis e flutuantes, devendo o ministro da Fazenda juntar à proposta de orçamento da despesa uma tabela com a nomenclatura dos serviços suplementáveis. Este anexo ao orçamento anual ficou conhecido como Tabela B, forma pela qual ela será adiante referida. Esta tabela, antecedente histórico das atuais margens de remanejamento, acompanhava o orçamento com a enumeração das dotações para as quais o governo poderia abrir créditos suplementares. Além disso, a lei de 1850 estabeleceu que os créditos suplementares somente poderiam ser utilizados pelo Executivo enquanto as Câmaras não estivessem funcionando e no caso de despesa tão urgente que não pudesse esperar nova reunião do Parlamento.

\footnotetext{
${ }^{198}$ Cf. extensa referência ao tema em ROURE, Agenor. Formação do Direito Orçamentário Brasileiro. Rio de Janeiro: Jornal do Commercio, 1916.

${ }^{199}$ VEIGA FILHO, J. Manual da Sciencia das Finanças. $3^{\mathrm{a}}$ ed. São Paulo: Secção de Obras d’O Estado, 1917, p. 287.
} 
Algumas leis orçamentárias posteriores ${ }^{200}$ trouxeram, também, uma limitação temporal, que se tornou tradicional nas legislações referentes do período e que constitui prática relativamente incomum no direito orçamentário comparado, que é a limitação temporal de abertura de crédito adicional. Nenhum crédito suplementar poderia ser aberto antes do nono mês do exercício financeiro, como uma medida para que o governo se cingisse às dotações orçamentárias aprovadas e tivesse que ao menos esperar que as consequências de deficiências na arrecadação efetivamente se sentissem antes de modificar o orçamento. Ademais, previram um limite quantitativo de 4 mil contos às suplementações.

A República manteve, inicialmente, a exigência de que se esperasse até o nono mês para modificar os créditos orçamentários. Na verdade, criou ainda uma condição: a de que o presidente do Tribunal de Contas se manifestasse sobre a legalidade da proposta de crédito suplementar (Lei de 12 de dezembro de 1892). As manifestações do presidente do Tribunal de Contas, porém, acabaram por se dar no sentido de que a abertura de créditos poderia ocorrer em qualquer mês.

A apreciação deste tema sempre foi crítica, tanto na doutrina como em setores do meio político. Em 1862, o visconde do Rio Branco, ministro da Fazenda, afirmou que os créditos suplementares poderiam ser dispensados ou reduzidos, se os serviços fossem convenientemente dotados. Apontou que o que impulsionava o alto volume de modificações no orçamento era a falta de sinceridade orçamentária. Nesta esteira, outro ministro da Fazenda, Silveira Martins, organizou proposta supressora da malfadada Tabela B, que "concorria para alterar os orçamentos e nulificar a fiscalização do Parlamento"201. Nesta ocasião, Silveira Martins defendeu as prerrogativas do Parlamento, num movimento contrário ao que posteriormente se verificaria de concentração de poderes orçamentários no Executivo.

Os créditos suplementares não funcionaram senão como um corolário da falta de transparência, clareza e sinceridade da proposta orçamentária, notando-se seu crescimento constante ao longo do tempo. Tudo em razão de verbas insuficientemente dotadas, despesas irrefletidamente cortadas pelo parlamento, ou propostas fictícias

\footnotetext{
${ }^{200}$ Leis de 9 de setembro de 1962 , de 20 de outubro de 1877, de 30 de outubro de 1882 e de 3 de setembro de 1884 .

${ }^{201}$ SILVEIRA MARTINS apud ROURE, Agenor. Formação do Direito Orçamentário Brasileiro. Rio de Janeiro: Jornal do Commercio, 1916, p. 167-8.
} 
elaboradas pela Administração. Problema ainda grave se tornou outra tabela, a Tabela A: contendo a relação dos créditos suplementares abertos no exercício anterior, servia de base para a elaboração da Tabela $\mathrm{B}$, num processo incremental que pouco observava as características conjunturais que efetivamente demandavam alterações orçamentárias. O procedimento supunha descaso com a importância do orçamento público. Verificouse, igualmente, que os créditos suplementares funcionavam, neste ciclo de incrementalismo, como motor do aumento das despesas, em razão do impacto que tinham em orçamentos futuros. Não eram os únicos responsáveis, é verdade; para isso concorriam também os créditos extraordinários, criados para os serviços novos.

As tentativas de limitação desta conduta vieram expressas em importantes documentos do direito orçamentário do início do período republicano, nomeadamente o Projeto do Código de Contabilidade de Didimo da Veiga, de 1903, apresentado como substitutivo ao projeto de Código do deputado Alfredo Varela. Apontavam-se como casos justificadores da suplementação aqueles em que:

a) as rubricas orçamentárias não fossem suficientes para prover às despesas a que se destinavam;

b) houvesse inadiável necessidade;

c) a rubrica estivesse compreendida na tabela de verbas suplementáveis (Tabela B);

d) a cifra não excedesse a 8.000 contos durante o exercício;

e) a utilização do crédito suplementar não importasse ampliação do serviço dotado no orçamento;

f) houvesse manifestação do presidente do Tribunal de Contas por sua legalidade; e

g) o Congresso não estivesse reunido.

Nota-se, aí, a exclusão do limite temporal do nono mês para o pedido do crédito. O Projeto de Didimo da Veiga tinha, neste aspecto, poucas diferenças do anterior, do deputado Alfredo Varela: este, diferentemente daquele, apontava à necessidade de 
prévio assentimento do ministro da Fazenda, determinava a observância do prazo de nove meses e traçava limite quantitativo de 2.000 contos (ampliado para 10.000 em caso de guerra).

O conjunto destes expedientes teve suas consequências expressas por Agenor de Roure: "o perigo e o mal do crédito suplementar está exatamente nisto - na certeza que tem o Executivo de ver atendidos os seus pedidos de suplementação de créditos para verbas fixas, originando abusos na aplicação dos dinheiros públicos."202 Para promover um equilíbrio orçamentário fictício na proposta orçamentária, recorria-se às alterações da lei, criando volume tal de créditos adicionais que se falava em "orçamento paralelo". Sendo, porém, utópico esperar que um governo administre sem recorrer a créditos adicionais, o desafio seria extinguir a "mentira orçamentária"203.

Parece ainda prevalecer a certeza do Executivo de ver aprovadas suas propostas de créditos adicionais. Este traço político do sistema orçamentário brasileiro contrasta com amplas prerrogativas parlamentares conferidas para sua abertura.

\subsubsection{Classificação}

Há três tipos de créditos adicionais: suplementares, especiais e extraordinários.

Suplementares são aqueles abertos para o reforço de dotações orçamentárias que, ao longo da execução, se mostraram insuficientes. Na dicção simples do art. 41, I, da Lei 4.320/64, são créditos suplementares os "destinados a reforço de dotação orçamentária". Suprem as deficiências de créditos orçamentários, mas também de créditos especiais, se a lei que os autorizou contiver autorização expressa neste sentido.

Rigorosamente, a suplementação não é dos programas orçamentários em si, mas dos recursos financeiros que os atenderão. Neste sentido, considerando-se que cada programa é o resultado de uma decisão política aprovada pelo Parlamento, melhor seria que não fosse possível a anulação de um programa para o reforço de outro, mas tão

\footnotetext{
202 ROURE, Agenor. Formação do Direito Orçamentário Brasileiro. Rio de Janeiro: Jornal do Commercio, 1916, p. 172.

203 ROURE, Agenor. Formação do Direito Orçamentário Brasileiro. Rio de Janeiro: Jornal do Commercio, 1916, p. 172.
} 
somente a anulação de determinados objetos de custo de cada programa, transferindo-se seus recursos para outra categoria prioritária. Isto num cenário de orçamento-programa tecnicamente adequado.

A seu turno, créditos especiais são aqueles que atendem a despesas que não tenham dotação orçamentária específica (art. 41, II, Lei 4.320/64). São abertos para um novo programa, projeto ou atividade, servindo para destinar-lhe os recursos para finalidades tais como pessoal, material e outras, que possibilitarão a concretização de seu produto, e também para a despesa propriamente dita. Desta forma, presta-se esta espécie ao aprimoramento do planejamento estatal inicialmente realizado.

Ainda, conforme o art. 167, $\S 1^{\circ}$, da Constituição Federal, se o programa tiver duração superior a um exercício financeiro, é necessária a inclusão deste crédito no Plano Plurianual, por lei específica, sob pena de crime de responsabilidade.

Os créditos extraordinários, de acordo com o art. 167, §3º da Constituição, têm sua abertura admitida para atender a despesas imprevisíveis e urgentes, como as decorrentes de guerra, comoção interna ou calamidade pública. Como o processo legislativo de sua criação é diferente dos demais, serão tratados em tópico apartado. Isto porque, conquanto as três modalidades de crédito adicional atendem a despesas não previstas, o crédito extraordinário é cabível em relação a fatos imprevisíveis, pelo texto constitucional. Isto é, aqueles que não podem ser previstos de acordo com os meios e as técnicas disponíveis, do que posteriormente se tratará. Ressalte-se que a Constituição fala em imprevisibilidade e urgência, sendo estes dois requisitos indispensáveis para caracterizar a extraordinariedade da medida. Não basta, deste modo, que a situação seja urgente, porém pudesse ter sido prevista. Por esta razão, sua abertura é autorizada por meio de medida provisória.

\subsubsection{Recursos disponíveis}

Os recursos dos créditos suplementares e especiais devem ser indicados na lei que os autoriza. Além disso, "a abertura de créditos suplementares e especiais depende da existência de recursos disponíveis para ocorrer à despesa e será precedida de exposição justificativa" (art. 43, Lei 4.320/64). 
Assinale-se que o caput do art. 43 da Lei 4.320/64 diz ser necessário haver recursos disponíveis. Isso significa que, no momento de efetivação da despesa, deve existir a possibilidade de já serem dispostos pela Administração. ${ }^{204} \mathrm{E}$, de acordo com o $\S 1^{\circ}$ deste artigo, os recursos que atendam às finalidades do caput não podem estar comprometidos, pois, evidentemente, neste caso não são recursos disponíveis. Assim,

\begin{abstract}
por recursos comprometidos, deve-se entender aqueles que em razão de contratos, convênios ou leis atenderão a despesas obrigatórias, tais como pessoal, amortizações de empréstimos, juros, inativos (aposentados) e pensionistas, bem como receitas vinculadas a caixas especiais (fundos especiais) institucionalizados para o atendimento de obrigações resultantes da execução de programas especiais de trabalho, que têm, assim, receitas e despesas comprometidas com os respectivos objetivos específicos. ${ }^{205}$
\end{abstract}

Os recursos que cobrirão os créditos adicionais, segundo os incisos do art. 43, $\S 1^{\circ}$, são, pois: o superávit financeiro apurado em balanço patrimonial do exercício anterior; os provenientes de excesso de arrecadação; os resultantes de anulação parcial ou total de dotações orçamentárias ou de créditos adicionais autorizados em lei; e o produto de operações de crédito autorizadas, em forma que juridicamente possibilite ao Poder Executivo realizá-las. Fica claro que estas espécies de recursos são numerus clausus, vedando-se que sejam apontados outros tipos.

\title{
4.1.1.2.1. Superávit financeiro
}

$\mathrm{O}$ art. $43, \S 2^{\circ}$, da lei 4.320/64, entende por superávit financeiro a diferença positiva entre o ativo financeiro e o passivo financeiro, conjugando-se, ainda, os saldos dos créditos adicionais transferidos e as operações de crédito a eles vinculadas.

Ativo financeiro e passivo financeiro são elementos constitutivos do patrimônio financeiro, devendo conjugar-se a eles os saldos de créditos adicionais transferidos e as operações de créditos vinculadas para que se possa apurar um superávit líquido. $\mathrm{O}$ art. $105, \S 1^{\circ}$, da Lei $4.320 / 64$ define que o ativo financeiro é composto dos créditos e valores realizáveis independentemente de autorização orçamentária e os valores numerários, ao passo que o passivo financeiro (art. 105, $\$ 3^{\circ}$ ) compreenderá as dívidas

\footnotetext{
${ }^{204}$ MACHADO Jr., José Teixeira; REIS, Heraldo da Costa. A Lei 4.320 comentada e a lei de responsabilidade fiscal. 31 $1^{\mathrm{a}}$ ed. Rio de Janeiro: IBAM, 2002/2003, p. 114.

${ }^{205}$ MACHADO Jr., José Teixeira; REIS, Heraldo da Costa. A Lei 4.320 comentada e a lei de responsabilidade fiscal. $31^{\mathrm{a}}$ ed. Rio de Janeiro: IBAM, 2002/2003, p. 114.
} 
fundadas e outros pagamentos independentes de autorização orçamentária. Havendo saldo neste balanço, poderão os recursos ser utilizados para cobrir créditos adicionais.

A apuração da existência de superávit financeiro é feita com o balanço patrimonial, no dia 31 de dezembro de cada ano. É aí que se verifica sua existência, que nada mais é que uma sobra líquida, totalmente disponível.

A Lei Complementar 101/2000, no art. $1^{\circ}, \S 1^{\circ}$, estabelece como um de seus objetivos a busca do equilíbrio das contas públicas, portanto uma compensação entre receitas e despesas. Também o art. $4^{\circ}$, I, a, desta lei dispõe que a Lei de Diretrizes Orçamentárias trate do equilíbrio entre receitas e despesas. No geral, os recursos utilizados para abertura de créditos adicionais provêm de situações que envolvem as receitas (por exemplo, excesso de arrecadação e operações de crédito), ou então a diminuição de outras despesas (anulação de dotações). Aumenta-se, pois, a despesa, através de uma contrapartida da receita ou da diminuição de ouras despesas, mantendose o equilíbrio. Pode-se diagnosticar, entretanto, que aqueles créditos adicionais abertos com recursos do superávit financeiro autorizam novas despesas sem alterar as receitas. Por este motivo, tais créditos tendem a produzir o déficit orçamentário, o que exigiria, tanto por parte do Governo como do Parlamento, esforço adicional para demonstrar, na justificativa e na apreciação do projeto, que a utilização do superávit financeiro será suficiente para evitá-lo.

\subsection{Excesso de arrecadação}

Pelo art. 43, $\S 3^{\circ}$, da Lei 4.320/64, “entende-se por excesso de arrecadação, para os fins deste artigo, o saldo positivo das diferenças, acumuladas mês a mês, entre a arrecadação prevista e a realizada, considerando-se, ainda, a tendência do exercício." Exige-se, desta forma, o acompanhamento do comportamento das receitas, evitando-se a má prática de subestimar a previsão das entradas justamente para obter mais facilmente este excesso. Os métodos dos órgãos encarregados da contabilidade devem ser criteriosos para que, ao apurar este excesso, não seja ele distorcido. Cálculos subestimados ocasionam o déficit no final do exercício financeiro. ${ }^{206}$ Naturalmente que,

\footnotetext{
${ }^{206}$ GIACOMONI, James. Orçamento Público. 13a ed. São Paulo: Atlas, 2005, p. 274.
} 
quanto mais aperfeiçoado o sistema de orçamento-programa, maior a tendência de que esta fonte de recursos tenha sua importância diminuída. ${ }^{207}$

Permite-se considerar, ainda, a "tendência do exercício" para apurar o excesso de arrecadação, o que deve ser entendido em consonância com o que dispõe o art. $4^{\circ}$, $\S 1^{\circ}$, da LC 101/2000, segundo o qual o Anexo de Metas Fiscais estabelecerá as metas anuais, em valores correntes e constantes, das receitas. De qualquer forma, não é possível vedar a utilização da tendência para apurar o excesso. Se assim não fosse, isto é, se fosse necessário o efetivo recebimento do excesso nos cofres do Tesouro, os créditos adicionais com estes recursos só poderiam ser abertos no final do exercício financeiro. Por outro lado, a justificativa da tendência do exercício requer maior cuidado na sua elaboração, demonstrando a possibilidade efetiva de sua ocorrência, não só em termos estatísticos, mas também apreciando-se os vários fatores que podem influenciála.

Estabelece, ainda, o $\S 4^{\circ}$ do art. 43, que, "para o fim de apurar os recursos utilizáveis, provenientes de excesso de arrecadação, deduzir-se-á a importância dos créditos extraordinários abertos no exercício."

É importante a ressalva de que o excesso deve ser apurado no conjunto das receitas, e não com relação a uma delas, isoladamente. Se as demais receitas estão se comportando aquém do previsto, não faria sentido usar-se o excesso de apenas uma delas para abrir o crédito adicional.

\subsection{Anulação parcial ou total de dotações}

Se determinadas dotações são parcial ou totalmente anuladas, o recurso restante pode ser utilizado para modificar outras dotações, incrementando-as ou criando outras novas. Neste caso, não há aumento da importância das despesas totais do orçamento, não sendo afetado, portanto, seu equilíbrio. Note-se que o art. $43, \S 1^{\circ}$, III, refere-se à possibilidade de utilização dos recursos da anulação de créditos orçamentários ou adicionais autorizados por lei. Não sendo o crédito extraordinário autorizado por lei, sua

\footnotetext{
${ }^{207}$ MACHADO Jr., José Teixeira; REIS, Heraldo da Costa. A Lei 4.320 comentada e a lei de responsabilidade fiscal. $31^{\mathrm{a}}$ ed. Rio de Janeiro: IBAM, 2002/2003, p. 116.
} 
anulação não pode fazer com que seus recursos sejam usados para cobrir outros créditos adicionais.

A escolha das despesas que serão abandonadas, como uma escolha política, deve levar em consideração que de nada adianta anularem-se "dotações consignadas para despesas essenciais, somente com o fito de criar recursos. Seria cobrir um santo, descobrindo outro.",208

\subsection{Operações de crédito}

As operações de crédito compõem as receitas de capital (art. 11, $4^{\circ}$, da Lei 4.320/64, com redação dada pelo Decreto-Lei 1.939/1982). São operações rigorosamente controladas pela Lei de Responsabilidade Fiscal. Seu art. 29, inciso III, as define como o

compromisso financeiro assumido em razão de mútuo, abertura de crédito, emissão e aceite de título, aquisição financiada de bens, recebimento antecipado de valores provenientes da venda a termo de bens e serviços, arrendamento mercantil e outras operações assemelhadas, inclusive com o uso de derivativos financeiros.

$\mathrm{O}$ art. 43, IV, da Lei 4.320/64 é expresso ao prescrever que os recursos provenientes de operações de crédito somente possam ser utilizados para a abertura de créditos adicionais "em forma que juridicamente possibilite ao Poder Executivo realizálas", evitando-se a utilização de operações de crédito sem base legal, econômica ou financeira. Nesse sentido, é preciso que as operações de crédito sejam autorizadas de tal modo que os compromissos possam ser satisfeitos sem que o crédito público fique abalado.

Uma questão que se coloca é se o produto da operação de crédito já precisa ter sido obtido no momento da abertura do crédito adicional. A respeito, o art. $7^{\circ}, \S 2^{\circ}$, da Lei 4.320/64, diz que

o produto estimado de operações de crédito e de alienação de bens imóveis somente se incluirá na receita quando umas e outras forem especificamente

\footnotetext{
208 MACHADO Jr., José Teixeira; REIS, Heraldo da Costa. A Lei 4.320 comentada e a lei de responsabilidade fiscal. $31^{\text {a }}$ ed. Rio de Janeiro: IBAM, 2002/2003, p. 115.
} 
autorizadas pelo Poder Legislativo em forma que juridicamente possibilite ao Poder Executivo realizá-las no exercício.

A operação deve ser, portanto, viável e a realização possível no exercício, realizando-se naquele ano. Outros impedimentos, por exemplo, que inviabilizariam as operações de crédito, são aqueles trazidos pela Resolução 43/01 do Senado Federal, a respeito do endividamento dos Estados e Municípios. A expectativa de recursos provenientes destas operações inviáveis não ensejaria a abertura dos créditos adicionais, ainda que não se exija, categoricamente, que primeiro deve haver o recurso para depois abrir o crédito.

\subsubsection{Compatibilidade dos créditos adicionais com as leis orçamentárias}

A necessária compatibilidade entre todas as leis orçamentárias e os créditos adicionais se destina a evitar a criação de orçamentos paralelos, alheios a um contexto de planejamento anterior e à decisiva manifestação da vontade parlamentar. A participação dos diferentes órgãos administrativos e legislativos se submete às determinações das leis orçamentárias, que geram efeitos à Administração. A elaboração da proposta é decidida em diferentes níveis hierárquicos administrativos, que devem ter por norte a consecução da decisão expressa no plano de médio prazo (Plano Plurianual), nas diretrizes específicas para o orçamento (Lei de Diretrizes Orçamentárias) e na Lei Orçamentária Anual.

$\mathrm{Na}$ organização dos orçamentos públicos no Brasil, os programas orçamentários devem ser compatíveis com o Plano Plurianual (art. 165, $\S 7^{\circ}$, da Constituição). Com isso, pode haver interesse não apenas em alterar a lei orçamentária, mas também alguma das metas, objetivos ou diretrizes do próprio plano plurianual. Neste caso não se tratará de crédito adicional, porque o PPA não quantifica dotações orçamentárias. É possível, contudo, que, em hipótese específica, a lei que abra crédito adicional preveja alteração do plano plurianual, além do fato de que uma alteração em algum dispositivo deste plano muito provavelmente acarretará a necessidade futura de alteração da lei orçamentária - e seja feita exclusivamente com tal propósito. Todas estas ações orçamentárias estão, portanto, mutuamente implicadas. 
As leis que instituem os planos plurianuais costumam prever hipóteses de sua modificação, que pode acontecer pela via legislativa ou por decreto do chefe do Poder Executivo, nas hipóteses em que estabeleça. Sendo por lei, a alteração por ocorrer por duas vias principais: projeto de lei de revisão anual do plano ou lei específica, ambos de iniciativa do chefe do Poder Executivo. ${ }^{209}$ Está aí reconhecida a possibilidade de alteração em bloco ou caso a caso do Plano Plurianual.

Na hipótese de lei de revisão anual, sua proposta deve ser encaminhada ao Congresso até o dia 31 de agosto e pode ter três finalidades distintas: incluir, alterar ou excluir um programa.

Para incluir um programa, tem-se tornado recorrente nos planos plurianuais a exigência de que haja diagnóstico sobre a situação do problema que se deseja enfrentar ou sobre a demanda da sociedade que se deseja atender e a indicação dos recursos que financiarão o programa proposto. Ao passo que, tratando-se de alteração ou exclusão, devem-se expor as razões que motivam a proposta.

É no caso de alteração e de inclusão de programa do PPA que as relações desta lei com a dos créditos adicionais fica mais clara. alteração, entende-se: a modificação da denominação, do objetivo ou do público-alvo do programa; a inclusão ou exclusão de ações orçamentárias; e alteração do título, do produto e da unidade de medida das ações orçamentárias. Nesta última situação (alteração do título, do produto e da unidade de medida das ações orçamentárias), a lei orçamentária anual ou leis que abram créditos adicionais podem promover a modificação do programa do PPA, desde que não modifiquem a finalidade da ação ou sua abrangência geográfica e mantenham a mesma codificação ( $\$ 4^{\circ}$ do art. 15 da Lei 11.653 , de 7 de abril de 2008). Por sua vez, a inclusão de um programa pode ser realizada mediante lei de abertura de crédito especial desde que ela apresente, em anexo específico, as informações referentes às projeções plurianuais e aos atributos constantes do Plano.

Fica o Poder Executivo autorizado, ainda, a modificar o PPA por ato próprio nos casos de: alteração do órgão responsável por programas e ações; alteração dos indicadores dos programas e seus respectivos índices; inclusão, exclusão ou alteração de

\footnotetext{
${ }^{209}$ Para exemplificar aquilo que, daqui por diante, for tratado sobre as alterações do PPA, cf. art. 15 da Lei 11.653, de 7 de abril de 2008 (PPA 2008-2011).
} 
ações e respectivas metas, no caso de ações não- orçamentárias; adequação da meta física de ação orçamentária para compatibilizá-la com alterações no seu valor, produto, ou unidade de medida, efetivadas pelas leis orçamentárias anuais e seus créditos adicionais ou por leis que alterem o Plano Plurianual; incorporação das alterações decorrentes da lei orçamentária; e incorporação da relação de obras inacabadas, observando as decisões do Tribunal de Contas da União sobre o assunto.

A LDO traz diretrizes específicas sobre as alterações orçamentárias, sendo as principais delas:

- é necessário informar o número de beneficiados nas respectivas metas quando for necessário incluir recursos na LOA e em seus créditos adicionais para atender a despesas com auxílio-alimentação ou refeição, assistência pré-escolar e assistência médica e odontológica, inclusive das entidades da administração indireta;

- os recursos aprovados na LOA e em seus créditos adicionais para contrapartida nacional de empréstimos internos e externos, bem como para o pagamento de amortização, juros e outros encargos, somente poderão ser remanejados para outras categorias de programação por meio da abertura de créditos adicionais propostos por intermédio de projetos de lei, com a exceção de poderem sê-lo por meio de decreto se estiverem contidos nos limites de créditos suplementares da LOA, desde que mantida a mesma finalidade;

- os recursos alocados na LOA, destinados ao pagamento de precatórios judiciários e de débitos judiciais periódicos vincendos e ao cumprimento de débitos judiciais transitados em julgado considerados de pequeno valor, incluídos os decorrentes dos Juizados Especiais Federais, somente poderão ser cancelados para a abertura de créditos adicionais com outra finalidade mediante autorização específica do Congresso Nacional;

- na abertura de créditos extraordinários, é vedada a criação de novo código e título para ação existente;

- a reabertura dos créditos especiais e extraordinários, conforme disposto no art. $167, \S 2^{\circ}$, da CF, será efetivada, se necessária, mediante ato próprio de cada Poder e do Ministério Público da União, até 31 de janeiro de 2011; 
- na estimativa das receitas do projeto de lei orçamentária anual e da respectiva Lei, poderão ser considerados os efeitos de propostas de alterações na legislação tributária e das contribuições, inclusive quando se tratar de desvinculação de receitas, que sejam objeto de proposta de emenda constitucional, de projeto de lei ou de medida provisória que esteja em tramitação no Congresso Nacional. Caso as alterações propostas não sejam aprovadas, ou o sejam parcialmente, até 60 dias após a publicação da LOA, de forma a não permitir a integralização dos recursos esperados, as dotações à conta das referidas receitas serão canceladas, em função da aplicação de diferentes percentuais sobre determinadas dotações, mediante decreto, nos 30 dias subseqüentes; e

- a elaboração e a execução da LOA 2011 e de seus créditos adicionais obedecerão aos princípios constitucionais da impessoalidade, da moralidade, da publicidade e da eficiência na Administração Pública, não podendo ser utilizadas para influir na apreciação de proposições legislativas em tramitação no Congresso Nacional $^{210}$.

A Lei Orçamentária Anual, por sua vez, é mais diretamente afetada pela abertura de créditos adicionais, em razão de sua função específica de reforçar ou criar novos programas. Entretanto, em razão do art. $165, \S 8^{\circ}$, da Constituição, não está vedada pelo princípio da exclusividade orçamentária a prévia autorização, na própria lei de orçamento, para abertura de créditos suplementares, nos limites percentuais que forem ali traçados. É o que se chama de margem de remanejamento - assunto a ser mais explorado posteriormente. Os orçamentos anuais, corriqueiramente, dispõem que esta abertura, feita por decreto presidencial, no âmbito federal, é autorizada desde que as alterações promovidas na programação orçamentária sejam compatíveis com a obtenção da meta de resultado primário estabelecida para o exercício fiscal referente, e que corram à conta dos recursos de excesso de arrecadação, estabelecendo destinações específicas $^{211}$.

\subsubsection{Fases administrativa e legislativa dos créditos adicionais}

\footnotetext{
${ }^{210}$ BRASIL. Ministério do Planejamento. Manual Técnico Orçamentário 2011. Brasília: Secretaria de Orçamento Federal, 2011 ( $5^{\mathrm{a}}$ versão), p. 91-2.

${ }^{211}$ Cf. arts. $4^{\circ}$ e $5^{\circ}$ da Lei 12.214 de 26 de janeiro de 2010.
} 
O estudo do processo orçamentário tende a levar em consideração, predominantemente, o processo legislativo orçamentário. Boa parte dele, porém, tende a se passar antes que as alterações sejam levadas ao Congresso Nacional, e nos respectivos órgãos legislativos estaduais e municipais, pelo que é de grande relevância observar também a fase administrativa de elaboração das propostas de abertura de créditos adicionais.

Uma primeira distinção é, porém, fundamental. Os créditos adicionais alteram uma situação jurídica pré-existente: ou dão nova quantificação a créditos orçamentários anteriormente previstos, ou criam novos programas e ações. Ou seja, trata-se da modificação de uma lei já em vigor (a lei orçamentária anual). Deste modo, a fase legislativa dos créditos adicionais não se confunde com a fase legislativa dos créditos orçamentários, ainda que esta tenha grande influência sobre aquela (assim como o tem a lei de diretrizes orçamentárias), porque a regulamentação do procedimento de modificação do orçamento pelo órgão competente, no plano administrativo, tem como base a legislação orçamentária vigente. A fase administrativa dos créditos adicionais encontra-se entre estas duas fases legislativas, que não hão de confundir-se, tendo por fundamento a lei orçamentária naquele exercício financeiro vigente, com vistas a iniciar outro processo legislativo, agora distinto, para alterá-la.

Esta sequência de procedimentos significa que a abertura de créditos adicionais é um conjunto articulado de ações - e por isso mostra-se tarefa bastante complexa. Assim é que se torna possível falar aqui, verdadeiramente, em "processo" de criação de tais créditos, pois se trata de uma sequência encadeada de atos que se concluem com um resultado final $^{212}$. Este resultado final é a elaboração do decreto de abertura de créditos suplementares, no caso daqueles previstos em prévia autorização da lei orçamentária anual, de medida provisória sobre créditos extraordinários, ou de projeto de lei, apto a cada uma das espécies de créditos adicionais.

Ao ser iniciado o processo legislativo de abertura de crédito adicional, não se está diante de uma extensão ou prorrogação da fase de elaboração do orçamento. Esta já se encerrou, seguindo os prazos constitucionais. A particularidade da aprovação dos créditos adicionais está em que ocorre na fase de execução orçamentária, da qual o

\footnotetext{
${ }^{212}$ Utilizam-se aqui as noções sobre processo administrativo expostas por Celso Antônio Bandeira de Mello (Curso de Direito Administrativo. 26ª ed. São Paulo: Malheiros, 2009, p. 480).
} 
Poder Legislativo é chamado a participar. Conquanto a decisão parlamentar não seja de execução da despesa em si, mas de autorização para execução de determinada dotação acima dos montantes anteriormente previstos, trata-se de uma participação constitucionalmente indispensável. Isto por si só indica que o Parlamento continua ativo durante a fase de execução, não havendo qualquer forma de hibernação entre as fases de aprovação e de controle, nas quais comumente as explicações sobre o ciclo orçamentário costumam restringir suas competências.

\subsection{Fase administrativa: alterações quantitativas e qualitativas}

Esta fase desenvolve-se, num primeiro momento, em três planos: o órgão central, os órgãos setoriais e as unidades orçamentárias ${ }^{213}$. O órgão central é, na esfera federal, a Secretaria de Orçamento Federal (SOF) do Ministério do Planejamento, Orçamento e Gestão, e a matéria é normatizada anualmente em atos administrativos, que regulamentam os procedimentos e os prazos.

As alterações propostas podem ser qualitativas ou quantitativas. Serão qualitativas se envolverem a criação de um novo programa. Esta alteração significa o surgimento de uma nova ação, com a consequência de ser necessário um novo subtítulo no orçamento. A proposta desta alteração pode partir tanto das unidades orçamentárias como dos órgãos setoriais ou da própria SOF. Caso não parta do órgão central (isto é, se provier das unidades orçamentárias ou dos órgãos setoriais), a solicitação deve seguir o procedimento explicado abaixo, no que couber: cada unidade menor encaminha-a à instância superior, que a apreciará nos limites de suas atribuições. No caso de alterações qualitativas, porém, as propostas federais não são encaminhadas apenas à SOF, mas também à Secretaria de Planejamento e Investimentos (SPI) do Ministério do Planejamento, Orçamento e Gestão. Se ambas então estiverem de acordo, o novo programa de trabalho será criado e disponibilizado no Sistema Integrado de Dados Orçamentários (Sidor) para, posteriormente, atender a suas necessidades específicas.

\footnotetext{
${ }^{213} \mathrm{O}$ mesmo foi observado por CONTI a respeito da fase administrativa de elaboração da lei orçamentária anual. Cf. CONTI, J. M. A Autonomia Financeira do Poder Judiciário. São Paulo: MP Editora, 2006, p. 77.
} 
Por serem quantitativas, tais alterações destinam-se a possibilitar a efetiva realização dos programas orçamentários por meio da alocação de recursos, cuja correta identificação é uma responsabilidade comum das unidades orçamentárias, dos órgãos setoriais e do órgão central. A primeira identificação da necessidade pode partir de qualquer um destes órgãos. Em qualquer caso, iniciando-se nas unidades orçamentárias ou nos órgãos setoriais, devem cumprir os objetivos, procedimentos e prazos estabelecidos nas Portarias da SOF, mediante acesso ao Sidor. Porém, caso a alteração quantitativa proceda a uma alteração qualitativa (isto é, se envolver a abertura de crédito especial ou extraordinário), é necessário utilizar, antes, o Processo de Proposta e Análise de Alterações Orçamentárias, no qual será cadastrado o novo Programa de Trabalho e obtido seu código ${ }^{214}$.

Por sua vez, no menor dos três planos administrativos mencionados, as unidades orçamentárias desempenham importante papel na identificação de exigências de suplementação de verbas ou de criação de novas dotações orçamentárias porque são elas que fazem as primeiras solicitações. Elas veiculam, em seu âmbito, as necessidades ali presentes. São as menores unidades responsáveis pela administração de recursos públicos, às quais o orçamento designa verbas específicas para seus programas ${ }^{215}$, ainda que não sejam as menores unidades administrativas. Revela-se, nesta tendência, um processo de elaboração administrativa das propostas de créditos adicionais "de baixo para cima".

A função que as unidades orçamentárias assumem é a de coordenação do processo de alterações orçamentárias no seu âmbito de atuação, articulando as necessidades das unidades administrativas que as compõem ${ }^{216}$. As propostas apresentadas referem-se às alterações vistas como necessárias tanto em termos qualitativos (criando um novo programa) como quantitativos (viabilizando a execução de um programa já existente).

\footnotetext{
${ }^{214}$ BRASIL. Ministério do Planejamento. Manual Técnico Orçamentário 2011. Brasília: Secretaria de

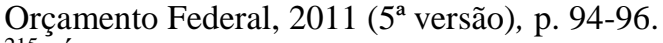

${ }^{215}$ É o que estatui o art. 14 da Lei 4.320/64, segundo o qual "constitui unidade orçamentária o agrupamento de serviços subordinados ao mesmo órgão ou repartição a que serão consignadas dotações próprias."

${ }_{216}$ BRASIL. Ministério do Planejamento. Manual Técnico Orçamentário 2011. Brasília: Secretaria de Orçamento Federal, 2011 (5 $5^{\mathrm{a}}$ versão), p. 93.
} 
Como já é possível perceber, o início desta fase se mostra complexo, pois cada uma das unidades orçamentárias já terá realizado um longo trabalho de averiguação das necessidades em seu âmbito de atuação (a partir das requisições das unidades administrativas), cada uma delas estabelecendo as suas próprias diretrizes. O início desta fase é, portanto, altamente atomizado e diversificado. Compete às unidades orçamentárias, além de fixar estas diretrizes, realizar estudos de adequação da estrutura programática do exercício. Igualmente, devem formalizar a sua proposta, a ser enviada ao devido órgão setorial, coordenar o processo de atualização e aperfeiçoamento das informações constantes do cadastro de atualizações orçamentárias, e analisar e validar as solicitações das respectivas unidades administrativas ${ }^{217}$.

Mas esta tendência "de baixo para cima" não é absoluta porque as propostas elaboradas pelas unidades orçamentárias devem ser compatíveis com os objetivos de médio e longo prazo das demais leis orçamentárias. Em razão disso, costumam as portarias da SOF estabelecer uma tabela em que constam diversos tipos de alterações do orçamento, nos quais se identificam tanto o fundamento legal da alteração como a forma (a espécie normativa adequada) para sua abertura, além da fonte dos recursos. Este processo de tipificação, que submete as alterações orçamentárias às determinações anteriormente feitas, com suas diretrizes já especificadas, também permite identificar no processo administrativo dos créditos adicionais momentos "de cima para baixo", embora, até aí, estes funcionem apenas como um limite dentro do qual podem ser feitas livremente as sugestões "de baixo para cima" ${ }^{218}$. Cabe, além disso, aos órgãos setoriais verificar a exatidão das informações que lhe são enviadas pelas unidades orçamentárias $^{219}$.

Os órgãos setoriais têm funções bastante semelhantes àquelas das unidades orçamentárias, coordenando e articulando as propostas em seu âmbito, analisando-as e validando-as. Também estabelecem diretrizes, avaliam a adequação das alterações aos

\footnotetext{
217 BRASIL. Ministério do Planejamento. Manual Técnico Orçamentário 2011. Brasília: Secretaria de

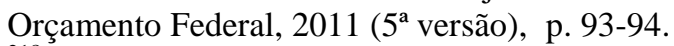

${ }^{218}$ Há outros momentos "de cima para baixo" na formação dos créditos adicionais, como quando, por exemplo, exigências conjunturais exigem alterações orçamentárias. O tema será desenvolvido, porém, em tópico específico, dispensando-se seu maior aclaramento nesta etapa.

${ }^{219}$ Foram analisadas as seguintes Portarias da SOF: $n .^{\circ}$ 07, de 01 de março de $2011 ;$ n. ${ }^{\circ}$, de 12 de janeiro de 2009; n. ${ }^{\circ}$ 7, de 28 de março de 2008; n. ${ }^{\circ}$, de 02 de fevereiro de 2007; n. ${ }^{\circ}$ 06, de 29 de maio de 2006; e n. ${ }^{\circ}$, de 16 de março de 2005. Estas portarias, embora se renovem anualmente (afinal, as leis de diretrizes orçamentárias e as leis orçamentárias são anuais), costumam apresentar sempre teor semelhante, identificando-se aí a constância do método de encaminhamento das propostas de alteração orçamentária.
} 
programas, formalizam ao órgão central do Ministério do Planejamento as propostas de sua área, coordenam e atualizam seu cadastro de programas e ações e definem suas instruções ${ }^{220}$.

Esta etapa do ciclo orçamentário é realizada por meio de sistema informatizado (o Sistema Integrado de Planejamento e Orçamento - SIOP), mediante o qual se encaminham as propostas, feitas por acesso online, ao órgão setorial do Sistema de Planejamento e de Orçamento Federal, ou equivalente, dos respectivos órgãos.

Os pedidos feitos pelas unidades orçamentárias interessadas são analisados pelos órgãos setoriais aos quais foram encaminhadas, que, então, avaliam globalmente a necessidade dos créditos solicitados e a possibilidade de compensação de recursos que serão utilizados em sua cobertura, incluindo-se esta análise na solicitação iniciada na unidade orçamentária.

Como já dito, as unidades orçamentárias devem enquadrar seus pedidos em uma das modalidades admitidas de créditos adicionais, de acordo com o art. 41 da Lei 4.320/64 - suplementares, especiais ou extraordinários. Não há, porém, um processo legislativo comum para a abertura destes créditos, cada qual passível de ser introduzido no sistema jurídico por espécies normativas diferentes, conforme o caso: decretos, leis ou medidas provisórias. Este tema será tratado com maior pormenorização em tópico posterior, mas nesta fase administrativa ele já é relevante em razão dos prazos estabelecidos para os órgãos setoriais encaminharem as propostas ao órgão central.

Conforme o veículo introdutor admitido para cada tipo de crédito adicional, estabelece-se um prazo distinto para que os órgãos centrais enviem a consolidação de suas propostas ao órgão central. No exercício de seu poder de coordenação, os órgãos setoriais podem estabelecer prazos específicos para as unidades orçamentárias de seu âmbito. Ainda, as portarias da SOF que regulam a matéria não raro trazem prazos especiais para determinadas despesas. Entende-se que a dilatação do prazo seria necessária para despesas imprevistas que podem surgir em qualquer período do ano, e que não poderiam ser calculadas senão por grosseira estimativa, ou então outras despesas que não podem deixar de ser feitas por imposição legal. Admite-se, então, que

\footnotetext{
${ }^{220}$ BRASIL. Ministério do Planejamento. Manual Técnico Orçamentário 2011. Brasília: Secretaria de Orçamento Federal, 2011 ( $5^{\mathrm{a}}$ versão), p. 93.
} 
os créditos adicionais previstos na LOA possam ser encaminhados até data bem próxima do final do exercício financeiro (comumente em fins de novembro), destinando-se, por exemplo, a despesas decorrentes de sentenças judiciais, de concessão de benefícios da seguridade social, ou de encargos e despesas com pessoal ${ }^{221}$. Ressaltese que, a partir de 2008, a SOF passou a incluir, nestes prazos especiais, as despesas com anistiados políticos, dando mais flexibilidade à sua cobertura, que com habitualidade vê a abertura de créditos suplementares que a elas se destinam autorizada pelas sucessivas leis orçamentárias anuais nos limites da margem de remanejamento mediante decreto, portanto.

O órgão central, além de definir as diretrizes para o processo de alterações orçamentárias, assume posição de comando, supervisão e orientação técnica dos órgãos setoriais e unidades orçamentárias. Compete-lhe, também, consolidar e formalizar as propostas de alterações orçamentárias da União. Isto significa que a SOF prepara, com definitividade, os atos destinados a abrir créditos adicionais. Estes atos podem ser decreto do Poder Executivo para os créditos suplementares previstos na lei orçamentária anual, projeto de lei para os créditos suplementares dependentes de autorização legislativa e para os créditos especiais, medida provisória para os créditos extraordinários e portaria da própria SOF quando se tratar de alterações de fontes de recursos, de identificador de uso ou de identificador de resultado primário.

Nota-se, pois, que muitas as alterações orçamentárias resolvem-se já nesta fase administrativa, desde que contenham autorização legal para tanto.

A abertura de créditos suplementares por decreto do Poder Executivo se dá nos limites da autorização prevista na Lei Orçamentária Anual, com fundamento no art. 165, $\S 8^{\circ}$, da Constituição. Uma apreciação crítica deste tópico será feita em item posterior, mas vê-se, já, que os decretos preparados pela SOF ocupam grande parte das normas administrativas referentes a créditos adicionais. Nos limites traçados pela Lei n. ${ }^{\circ}$ 12.381, de 9 de fevereiro de 2011 (Orçamento para 2011), nota-se, a título exemplificativo, que são 32 as modalidades de eventos (algumas das quais se desdobram em outras) cuja suplementação é autorizada por decreto do Executivo. Além

\footnotetext{
${ }^{221}$ Cf. Portarias da SOF n. ${ }^{\circ} 07$, de 01 de março de 2011; n. ${ }^{\circ}$, de 12 de janeiro de 2009; n. ${ }^{\circ} 7$, de 28 de março de 2008; n. ${ }^{\circ} 4$, de 02 de fevereiro de 2007; n..$^{\circ} 06$, de 29 de maio de 2006; e n. ${ }^{\circ} 3$, de 16 de março de 2005
} 
daquelas incluídas na margem de remanejamento normalmente de 10\% (descrita como Tipo 100 nas Portarias da SOF), há outras tantas em que o limite é bem maior, tais como a autorização para anulação de até $50 \%$ das dotações de mesmo Grupo de Natureza de Despesa (GND), que podem ser dentro deste limite remanejadas, por exemplo, nas dotações do Instituto Nacional de Educação dos Surdos e do Colégio Pedro II (LOA 2011, art. 4, XII, alínea “a”, item 1).

Mas muitas destas alterações sequer chegam a ser feitas pelo Presidente da República. Basta, para elas, portaria do Ministro do Planejamento ou do próprio Secretário do Orçamento Federal, o que mostra o grau de importância de órgãos do Executivo na execução orçamentária. Estas alterações, que não se incluem entre os créditos adicionais, destinam-se a alterar as fontes de financiamento do Orçamento de Investimento e as fontes de recursos, as modalidades de aplicação e os identificadores de uso e de resultado primário, as metas, os produtos, as unidades de medida e as esferas orçamentárias das ações constantes da lei de orçamento e dos créditos adicionais, inclusive os reabertos no exercício. O ato do Ministro do Planejamento, Orçamento e Gestão destina-se às alterações das fontes de recursos, indicadores de uso e modalidades de aplicação do Orçamento de Investimentos, ao passo que as outras são realizadas por ato da SOF. A LDO para 2011 (art. 66), ainda exemplificativamente, autoriza que decreto do Poder Executivo transponha dotações orçamentárias de uma unidade orçamentária para outra, no caso de reestruturação organizacional do Poder Executivo ou de transferência de atribuições de unidade, órgão ou entidade extintos, transformados, transferidos, incorporados ou desmembrados. Chama a atenção, ainda, que os recursos abertos por crédito extraordinário também podem, atualmente, ser remanejados por decreto, caso se destinem a outras despesas decorrentes de calamidades públicas (LDO 2011, art. 58, $\S 2^{\circ}$ ).

Após a publicação destes atos no Diário Oficial da União, a SOF procederá à efetivação dos créditos publicados no SIDOR e transmitirá as informações à Secretaria do Tesouro Nacional (STN), que as disponibilizará no SIAFI e gerará as notas de dotação para as unidades gestoras que poderão utilizar os créditos adicionais. 


\subsection{Iniciativa da fase legislativa}

A expressão processo legislativo refere-se ao "conjunto de atos (iniciativa, emenda, votação, sanção, veto) realizados pelos órgãos legislativos visando a formação das leis constitucionais, complementares e ordinárias, resoluções e decretos legislativos" ${ }^{222}$. A elaboração de leis financeiras (planos plurianuais, leis de diretrizes orçamentárias, leis orçamentárias anuais e créditos adicionais) segue procedimento legislativo especial, conforme enuncia o art. 166 da Constituição Federal.

O art. 42 da Le 4.320/64 dispõe que "os créditos suplementares e especiais serão autorizados por lei e abertos por decreto executivo." Faz parte das competências do Congresso Nacional analisar projetos de lei relativos a créditos adicionais, conforme o art. 166 da Constituição Federal. Cabe a uma comissão mista permanente de Senadores e Deputados "examinar e emitir parecer sobre os projetos referidos neste artigo [o que inclui aqueles sobre créditos adicionais] e sobre as contas anualmente apresentadas pelo Presidente da Republica" (art. 166, § $1^{\circ}, \mathrm{I}, \mathrm{CF}$ ).

A Constituição, porém, não define expressamente a competência para iniciar o processo legislativo de créditos suplementares e especiais. A questão da iniciativa legislativa em matéria financeira tem se mostrado mais complexa do que a tendência geral de imaginar o orçamento como atividade material do Executivo permitiria supor. Em vista da primazia do Poder Legislativo na atividade legiferante, a falta de previsão expressa de competência do Poder Executivo nesta matéria apenas pode conduzir à conclusão, bem expressa por Conti, de que a iniciativa legislativa nos projetos de lei de créditos suplementares e especiais não é reservada ao Chefe do Poder Executivo. Seguem a iniciativa geral do Poder Legislativo nos casos em que não há expressa disposição constitucional em contrário $^{223}$. Todavia, uma interpretação constitucional sistemática não deve permitir que o Poder Legislativo possa alterar dotações orçamentárias, na fase de execução, em casos nos quais não poderia fazê-lo na fase de elaboração. As limitações materiais às emendas parlamentares previstas no art. $166, \S 3^{\circ}$, da Constituição, se aplicam, portanto, também aos créditos suplementares e especiais, que devem ser compatíveis com o PPA e a LDO e indicar os recursos necessários,

\footnotetext{
${ }^{222}$ SILVA, José Afonso da. Curso de Direito Constitucional. 30ª ed. São Paulo: Malheiros, 2008, p. 524.

${ }^{223}$ CONTI, J. M. Iniciativa Legislativa em Matéria Financeira. In: CONTI, J. M.; SCAFF, F.F. (coords.). Orçamentos Públicos e Direito Financeiro. São Paulo: RT, 2011, p. 296.
} 
admissíveis aqueles provenientes da anulação de despesas. Evita-se, desta maneira, que surjam iniciativas desarticuladas de créditos adicionais, comprometedoras do equilíbrio orçamentário e do planejamento.

\subsubsection{Período de vigência}

A vigência dos créditos adicionais fica adstrita ao exercício financeiro em que foram abertos, salva expressa disposição legal em contrário a respeito dos especiais e extraordinários (art. 45, Lei 4.320/64). A expressa disposição em contrário, todavia, ocorre no plano constitucional: de acordo com o art. 167, §2 , da Constituição, "os créditos especiais e extraordinários terão vigência no exercício financeiro em que forem autorizados, salvo se o ato de autorização for promulgado nos últimos quatro meses daquele exercício, caso em que, reabertos nos limites de seus saldos, serão incorporados ao Orçamento do exercício financeiro subseqüente."

Vê-se, então, que a vigência dos créditos suplementares vai até o dia 31 de dezembro do respectivo exercício financeiro, independentemente da data em que tenham sido abertos; os créditos especiais e extraordinários poderão ter vigência superior à do exercício financeiro se o ato de sua autorização (lei, no caso dos especiais, e medida provisória, no caso dos extraordinários) for promulgado durante os últimos quatro meses do exercício. Serão, portanto, incorporados à execução orçamentária do exercício financeiro subseqüente.

Esta vigência plurianual do crédito especial é justificada pelo fato do projeto de Lei Orçamentária Anual ser encaminhado ao Congresso quatro meses antes do fim do exercício financeiro (art. 35, $\S 2^{\circ}$, III, ADCT). Abrindo-se crédito especial neste período, que vai de agosto e dezembro, fica claro que a despesa imprevista que se pretende criar não encontra dotação no orçamento subseqüente, já enviado ao Congresso e em tramitação. Para garantir sua execução, portanto, admite-se sua reabertura. 


\subsubsection{Transferências, remanejamentos e transposições}

O gênero das transferências de verbas dentro do próprio orçamento foi introduzido no Brasil, com inspiração francesa, para limitar o uso de créditos suplementares. Tanto na monarquia como na república previu-se que as leis de orçamento poderiam ser retificadas por decretos que tratassem de erros de redação. Esgotado o crédito previsto para cada exercício, os orçamentos anuais continham a chamada Tabela B, que previa uma lista com autorização prévia para abertura de créditos suplementares (antecessora das atuais "margens de remanejamento", das quais posteriormente se tratará). Caso também estas suplementações não fossem suficientes, o governo ficava proibido de abrir créditos suplementares, embora pudesse, de início, recorrer ao estorno de verbas, isto é, à transferência entre os recursos orçamentários. A prática foi, depois, vedada ${ }^{224}$.

O estorno existiu como um recurso legalmente previsto, permitido na execução orçamentária, para aplicação das verbas de uns serviços em outros, quando houvesse sobra. O Parlamento brasileiro, historicamente, acostumou-se a consentir com as propostas do Poder Executivo, embora em movimentos cíclicos de abolição e restabelecimento do instituto, até que fosse definitivamente suprimido da legislação em 1878. ${ }^{225}$ A França já proibira o virement de crédit em 1871. O estorno existiu no país, porém, mesmo depois de aperfeiçoado o sistema de classificação e especialização da despesa, mas a evolução destes sistemas de detalhamento foi dificultando a prática daquele. Castro Carreira datou a existência do estorno em lei de 8 de outubro de 1843, do que discorda Agenor de Roure ao constatar que o orçamento para o exercício de 1833-1834 já previa as transferências de recursos utilizando as sobras ${ }^{226}$.

Quando o sistema orçamentário brasileiro admitia largamente despesas globais, o estorno podia ser livremente feito pelo governo, independentemente de previsão legislativa, porque o responsável pela execução da despesa dificilmente transbordava o limite de recursos que lhe havia sido em largas linhas traçado. Tão largas que mal eram

\footnotetext{
${ }^{224}$ ROURE, Agenor. Formação do Direito Orçamentário Brasileiro. Rio de Janeiro: Jornal do Commercio, 1916, p. 203.

${ }^{225}$ ROURE, Agenor. Formação do Direito Orçamentário Brasileiro. Rio de Janeiro: Jornal do Commercio, 1916, p. 203.

${ }^{226}$ ROURE, Agenor. Formação do Direito Orçamentário Brasileiro. Rio de Janeiro: Jornal do Commercio, 1916, p. 204.
} 
limites. De fato, as dotações orçamentárias podiam ser vagas a ponto de possibilitar o atendimento das mais diferentes finalidades sob uma mesma rubrica.

O problema é antigo. O recurso ilimitado ao estorno desapareceu em 1878, mas permaneceram os créditos suplementares depois de então. Acreditava-se, tanto no Brasil como na França, que a possibilidade de estornar verbas evitaria o uso de créditos adicionais e manteria o Executivo nos limites da dotação aprovada. Quando os virements de crédit se introduziram na legislação francesa, tinham semelhante finalidade de proibir o uso de créditos suplementares para cobrir despesas variáveis, mas em poucas décadas viu-se que a prática não funcionava desta maneira. O Brasil manteve-se crédulo por mais tempo a respeito desta tese. $\mathrm{O}$ fracasso do estorno na França fez, lá, surgir o recurso aos orçamentos de retificação, criados por lei de 31 de Maio de 1862. Tratava-se de um segundo orçamento que modificava, de acordo com as necessidades, as previsões e autorizações contidas na lei orçamentária anual. Nova tentativa de substituir o abuso aos créditos suplementares, ficando em recurso na França até o fim do império de Napoleão III. Adotava-se este sistema de retificação também na Itália sob a denominação de orçamento definitivo ${ }^{227}$. Diversos foram os remédios, assim, para substituir os créditos suplementares. $\mathrm{O}$ uso do estorno sem autorização legal passou a ser, no Brasil, considerado crime contra a lei orçamentária, de acordo com o art. 10 da Lei $\mathrm{n} .^{\circ} 1.079$, de 10 de abril de 1950, que tipifica os crimes de responsabilidade do Presidente da República.

A atual Constituição deixou de prever, dentre as vedações orçamentárias, a proibição do estorno de verbas, ao menos explicitamente. Incluiu entre elas, entretanto, a vedação da transposição, do remanejamento e das transferências de uma categoria da programação para outra ou de um órgão para outro, sem prévia autorização legislativa (art. 167, VI). Em muitos sentidos não fica claro se estes instrumentos de flexibilidade têm natureza distinta dos créditos adicionais. Como a Constituição, porém, os tratou em item específico, separados das normas que regulam aqueles créditos, é necessário perquirir se há finalidades específicas, diferentes daquelas abrangidas pelos créditos adicionais, que devem ser por eles atendidas.

227 ROURE, Agenor. Formação do Direito Orçamentário Brasileiro. Rio de Janeiro: Jornal do Commercio, 1916, p. 204. 
Para Machado Jr. e Teixeira Reis, algumas necessidades de alteração orçamentária não ensejam a abertura de créditos adicionais, mas a utilização de outros meios de flexibilização do orçamento. Reforma administrativa, repriorização das ações governamentais e repriorização de gastos produzem a necessidade de transposição, transferência ou remanejamento de recursos, respectivamente, e não provocam a alteração orçamentária por meio de créditos adicionais. Estes autores justificam sua posição argumentando que a ocorrência dos referidos fatos provoca alterações nos três níveis da programação orçamentária: institucional, programático e de gastos. No âmbito da organização (plano de programação institucional) há possibilidade de remanejamento de recursos. Assim, por exemplo, se ocorre reforma administrativa que extingue um órgão e cria outro em seu lugar, remanejam-se os recursos remanescentes daquele para este. No plano programático podem ocorrer transposições, repriorizando-se programas de trabalho e deslocando-se recursos de programas entre si. Em termos de gastos, podem-se transferir recursos da categoria das despesas, no caso da prioridade destas ser revista. São alterações orçamentárias, como se nota, que ocorrem por mudanças significativas no planejamento orçamentário ${ }^{228}$. A diferença central entre os dois institutos estaria, portanto, no fato de que os créditos adicionais são abertos porque há necessidade de recursos até então inexistentes; no caso da transposição, do remanejamento e da transferência, está em realce a reprogramação por repriorização das ações.

É preciso esclarecer a que se refere a locução "categoria da programação" trazida pelo referido art. 167, VI, da Constituição. Trata-se, segundo a Portaria $n^{\circ} 42$, de 14/04/1999, do Ministério do Planejamento, Orçamento e Gestão, da função, da subfunção, do programa, do projeto/atividade/operação especial e das categorias econômicas de despesas. Vedando-se a transposição, o remanejamento ou a transferência de recursos de uma categoria da programação para outra ou de um órgão para o outro, realiza-se o princípio da vedação do estorno de verbas, ao qual Constituições anteriores se referiam.

A diferença entre as três categorias estaria, portanto, na extensão da alteração que promovem: para alterações no nível institucional, remanejamentos; no nível da programação, transposições; no nível dos gastos, transferências. E estas formas jurídicas

\footnotetext{
228 MACHADO Jr., José Teixeira; REIS, Heraldo da Costa. A Lei 4.320 comentada e a lei de responsabilidade fiscal. $31^{\text {a }}$ ed. Rio de Janeiro: IBAM, 2002/2003, p. 108.
} 
seriam diferentes dos créditos adicionais porque estes, ao contrário daquelas, não produzem alterações de maior relevância e impacto. Por isso é que deveriam ser utilizados com menos freqüência e ser sempre precedidos de exposição justificativa ${ }^{229}$.

$\mathrm{O}$ argumento de que a diferença entre os créditos adicionais e as transferências aqui consideradas (para utilizar genericamente o termo, abrangendo também os remanejamentos e transposições) está no fato de que apenas estas últimas alteram significativamente o planejamento parece extrair conclusões demais. Ainda que as suplementações de verbas fossem fato de menor importância e impacto no orçamento, não fica claro em que a suplementação decorrente da anulação de outras dotações orçamentárias se diferenciaria das transferências em sentido estrito - aquelas que procedidas no plano dos gastos. A própria perspectiva de que alterar montantes orçamentários não é medida de maior relevância deve ser repensada: a especialidade do orçamento desdobra-se não apenas na definição dos programas, mas também em seus montantes, que são a medida da consecução daquele objetivo.

Ademais, ao tentar distinguir estes institutos dos créditos adicionais, os critérios adotados se preocupam em fazer comparações com as suplementações, isto é, com os créditos suplementares; não abordam, entretanto, o aspecto dos créditos especiais, que fazem despesa nova. Criam, portanto, novo programa. Não se trata aí, obviamente, de mero incremento na dotação (o que, repita-se, não é medida de impacto tão desprezível assim no planejamento), mas de criação de nova despesa. E isso não é decorrência necessária de emergências, calamidades, comoções etc., que ensejariam a abertura de créditos extraordinários, mas da própria repriorização de ações, de programas e de gastos, com atribuição de novos encargos a determinados órgãos incumbidos de realizar a despesa nova.

As margens de remanejamento orçamentárias, além disso, indicam frequentemente a possibilidade de usar recursos de outras dotações para cobrir as suplementações, que serão feitas por decreto do chefe do Executivo ${ }^{230}$.

\footnotetext{
${ }^{229}$ Cf. Consulta n. ${ }^{\circ}$ 742.472/ TC-MG. Rel. Min. Wanderley Ávila, 07/05/2008.

${ }^{230} \mathrm{Cf}$. as tabelas indicadoras dos recursos das portarias da SOF que regulam a abertura de créditos adicionais (Portarias n..$^{\circ}$ 07, de 01 de março de 2011; n..$^{\circ}$, de 12 de janeiro de 2009; n. ${ }^{\circ}$ 7, de 28 de março de 2008; n. ${ }^{\circ}$ 4, de 02 de fevereiro de 2007; n. ${ }^{\circ}$ 06, de 29 de maio de 2006; e n. ${ }^{\circ} 3$, de 16 de março de 2005).
} 
Por tudo isso, a diferença entre transposições, remanejamentos e transferências e créditos adicionais não é substancial. Há, na realidade, dois institutos admitidos para atingir o mesmo objetivo: cobrir despesas não previstas no orçamento, ou por meio da criação de novo programa, ou mediante o reforço da dotação anterior. Parece igualmente lógico que transferir, remanejar ou transpor recursos de uma dotação para outra necessariamente significará a diminuição de uma dotação para o aumento de outra: esta dotação incrementada poderia perfeitamente sê-lo por crédito adicional. Isto se reforça pelo argumento histórico: sua introdução no ordenamento jurídico brasileiro foi justificada com o fim de restringir o uso de créditos adicionais por meio da permissão de que despesas variáveis fossem atendidas pelas transferências, ou pelo estorno. Atualmente, porém, esta restrição às despesas variáveis não encontra mais fundamento normativo.

Da mesma forma, tão idêntica é a finalidade entre ambos os instrumentos de flexibilidade do orçamento que para eles se prevê o mesmo trâmite legislativo: é preciso que haja autorização legislativa específica tanto para a abertura de créditos suplementares e especiais como para as transferências, remanejamentos e transposições.

Um comentário de lege ferenda merece ainda ser feito. Já há muito se desviando da finalidade de atender exclusivamente despesas variáveis, encontram-se hoje procedimentos técnicos de estimativa e execução adequados ao seu bom atendimento, sem que sejam permitidas dotações globais ou créditos ilimitados. É, portanto, de se perguntar sobre a necessidade de permanência de institutos diversos dos créditos adicionais, visto que as necessidades de reprogramação mais profundas podem ser atendidas por estes sem prejuízo para a transparência das contas. Isto já vem sido dito há algum tempo, e a conclusão não é nem nova nem original. Aproveitando-se de uma sugestiva ilustração, Agenor de Roure observava que, inseridos o sistema das transferências autorizadas por lei no sistema orçamentário para diminuir os créditos adicionais, ocorreu o mesmo que quando se colocou no país a formiga cuiabana para combater a saúva. Postas umas, ficaram todas ${ }^{231}$.

\footnotetext{
231 ROURE, Agenor. Formação do Direito Orçamentário Brasileiro. Rio de Janeiro: Jornal do
} Commercio, 1916, p. 204. 


\subsection{Controle parlamentar fraco}

\subsubsection{Créditos extraordinários}

Conquanto a Constituição vede a edição de medidas provisórias sobre matérias relativas a orçamento e a "créditos adicionais e suplementares",232 (art. 62, §1, alínea “d”), seu art. $167, \S 3^{\circ}$, aponta ser aquela espécie normativa a adequada para a abertura de créditos extraordinários, que são aqueles destinados a despesas imprevisíveis e urgentes. $\mathrm{O}$ uso de medida provisória em matéria orçamentária exige, pois, além dos característicos de urgência e relevância desta espécie, o requisito da imprevisibilidade que justifica a ação excepcional por crédito extraordinário. Neste sentido, a norma constitucional de 1988 revogou o art. 44 da Lei 4.320/64, que previa o decreto do Poder Executivo para sua abertura. A edição de ato administrativo próprio do chefe do Poder Executivo fazia parte da tradição orçamentária brasileira referente à matéria. A nova norma parece vir num contexto de valorização do Poder Legislativo no processo orçamentário, pelo que este deve se manifestar, ainda que posteriormente, mas de maneira definitiva, sobre norma introdutora de créditos extraordinários.

Embora a referência à submissão dos créditos extraordinários à forma e ao procedimento de medida provisória seja, no art. $167, \S 3^{\circ}$, da Constituição, feita em redação confusa $^{233}$, sem referência direta a esta espécie normativa, não há como prosperar a posição de que a interpretação que vem sendo feita do dispositivo é equivocada. ${ }^{234} \mathrm{O}$ art. $62, \S 1^{\circ}$, alínea "d", ao vedar medida provisória em matéria de créditos adicionais, ressalva explicitamente o disposto no art. $167, \S 3^{\circ}$, que se refere aos créditos extraordinários. Não bastasse, seria necessário indicar que outra espécie normativa ou ato administrativo seriam adequados para abrir este tipo de crédito, no caso de ser inapta a medida provisória. O retorno ao sistema dos decretos não encontra mais respaldo no texto constitucional - contraria o esquema de prerrogativas parlamentares na aprovação de mudanças no orçamento público. Em nenhum momento a Constituição autoriza o decreto em matéria orçamentária, que se assemelharia a um

\footnotetext{
${ }^{232}$ Note-se a imprecisão terminológica do legislador constituinte neste dispositivo, como se os créditos suplementares não fossem espécies de créditos adicionais.

${ }^{233}$ Art. 167, $\S 3^{\circ}$ : A abertura de crédito extraordinário somente será admitida para atender a despesas imprevisíveis e urgentes, como as decorrentes de guerra, comoção interna ou calamidade pública, observado o disposto no art. 62. (grifo nosso)

${ }^{234}$ Para negar a possibilidade de abertura por medida provisória, cf. SANCHES, Osvaldo M., Processo orçamentário federal: problemas, causas e indicativos de solução. Revista de Administração Pública, Rio de Janeiro, v. 29, n. 3, p. 146-7, jul./set. 1995.
} 
decreto autônomo por inovar a lei. É indispensável, portanto, a autorização legislativa, ainda que, neste caso, se dê apenas em momento posterior. Por tudo isso, a medida provisória é medida cabível.

A necessidade de fazer com que necessidades públicas urgentes possam ser dispensadas da aprovação por lei, mais demorada, para seu pronto atendimento, existe também em outros sistemas constitucionais. A Constituição alemã foi mais detalhada em seu art. 112 ao admitir a adoção de despesas que ultrapassem ou estejam fora do orçamento, com o requisito de que se trate de uma necessidade imprevista (unvorhergesehen) e inevitável (unabweisbar). O Tribunal Constitucional Federal, em decisão de 25 de maio de $1977^{235}$, determinou que a imprevisibilidade não pode ser exclusivamente interpretada em seu sentido objetivo. Assim, imprevista não é apenas a necessidade objetivamente imprevisível, mas também aquela que, de fato e independentemente do motivo, não foi prevista pelo governo ou pelo parlamento na aprovação do orçamento. Ou então aquela despesa cuja crescente urgência, que entrementes se originou de mudanças nas circunstâncias, tampouco foi prevista. ${ }^{236}$ Ainda que por erro do planejamento do governo, ou desatenção do legislativo, ou menosprezo do risco de mudanças conjunturais, é admitida a adoção destas alterações orçamentárias (über- und außerplanmäßige Ausgabe, art. 112, GG). Combinadas, porém, com o outro requisito: o da inevitabilidade.

$\mathrm{Na}$ mesma decisão da corte constitucional alemã, definiu-se o requisito da inevitabilidade em função da urgência da despesa, tanto em termos materiais (a relevância da matéria) como temporais (sua impostergabilidade). Somente se qualifica como inevitável o gasto que não possa ser deixado para frente sem prejuízo de sérios interesses políticos, econômicos e sociais do Estado. Esta barreira à competência do ministro das Finanças significa que apenas abre-se espaço para a observação da inevitabilidade se a despesa adicional for tão urgente que não possa aguardar um orçamento adicional ou um orçamento complementar ou simplesmente sua inclusão no

\footnotetext{
${ }^{235}$ BVerGE 45, 1 (1977).

${ }^{236}$ No original: "Unvorhergesehen ist nicht nur ein objektiv unvorhersehbares Bedürfnis, sondern jedes Bedürfnis, das tatsächlich, gleich aus welchen Gründen, vom Bundesminister der Finanzen oder der Bundesregierung bei der Aufstellung des Haushaltsplans oder vom Gesetzgeber bei dessen Beratung und Feststellung nicht vorhergesehen wurde oder dessen gesteigerte Dringlichkeit, die es durch Veränderung der Sachlage inzwischen gewonnen hat, nicht vorhergesehen worden ist." (BVerGE 45,1[98])
} 
orçamento do próprio exercício financeiro subsequente. ${ }^{237}$ Com base neste entendimento, o Tribunal Constitucional Federal alemão não tem se furtado a declarar nulas estas despesas não contidas no orçamento e mesmo orçamentos adicionais inteiros (Nachtragshaushaltsgesetze), nos quais as incompletudes e insuficiências nas estimativas iniciais tornem inaplicáveis os princípios constitucionais da transparência, da exatidão e da sinceridade orçamentárias, destinando-se os orçamentos do meio de exercício a promover o endividamento público em limites significativamente maiores que aqueles informados no orçamento inicial ${ }^{238}$.

Ambas as definições reforçam que os instrumentos de flexibilidade orçamentária não estão à disposição do chefe do Executivo para mudar o orçamento quando e como ele quiser; está autorizado a alterá-lo em razão de necessidades circunstanciais imprevistas, urgentes e impostergáveis.

Inobstante a participação do Poder Legislativo, ela se dá em momento posterior, seguindo os prazos para aprovação de medida provisória, quando uma ocasional rejeição pode ser inócua: a despesa pode já ter sido realizada, criando-se um fato consumado. Isto é agravado pela falta de clareza quanto às hipóteses em que é cabível a abertura do crédito extraordinário.

A disciplina constitucional dos créditos extraordinários, que o direito brasileiro não tratou a questão das alterações orçamentárias da mesma maneira como é feito na Alemanha, cuja Constituição Financeira serviu de modelo à organização das leis orçamentárias brasileiras. A diferença está na interpretação do que significa a imprevisibilidade. No direito germânico, como visto, a norma constitucional não se cinge à imprevisibilidade objetiva, podendo ser cobertas por créditos extraordinários mesmo aquelas despesas que podiam ser perfeitamente previstas, mas não o foram, independentemente do motivo. A Constituição brasileira, porém, fornece elementos para que se entenda a imprevisibilidade em termos mais objetivos, embora não o diga expressamente. Isto porque o art. $167, \S 3^{\circ}$, exemplifica situações que serão atendidas

\footnotetext{
237 No original: "Nur wenn eine Ausgabe ohne Beeinträchtigung schwerwiegender politischer, wirtschaftlicher oder sozialer Staatsinteressen nicht mehr zeitlich aufgeschoben werden kann, besteht für sie ein unabweisbares Bedürfnis. Diese Schranke für die Kompetenz des Bundesministers der Finanzen bedeutet: Erst wenn eine Mehrausgabe so eilbedürftig ist, dass die Einbringung eines Nachtragshaushaltsplans oder eines Ergänzungshaushaltsplans oder schließlich ihre Verschiebung bis zum nächsten regelmäßigen Haushalt bei vernünftiger Beurteilung der jeweiligen Lage als nicht mehr vertretbar anerkannt werden kann, liegt ein Fall der Unabweisbarkeit vor." (BVerGE 45,1[102])

${ }^{238}$ BVerfG, 2 BvF 1/04, de 9.7.2007, parágrafos 1-220.
} 
por esta medida orçamentária emergencial. Fala em situações "como as decorrentes de guerra, comoção interna ou calamidade pública”. A Carta indica sua preferência por situações graves, marcadas pela imperiosidade de seu atendimento. Pelo que urgência e imprevisibilidade se tornam requisitos mutuamente dependentes para caracterizar a legitimidade constitucional da abertura de créditos extraordinários, não podendo ser atendidos por este instrumento aqueles casos em que a despesa não prevista está despida da nota da emergência. Os exemplos constitucionais não permitem que se equipare o erro de planejamento do governo, que não previu despesas corriqueiras, a casos de relevante magnitude e comoção social. Por isso, a imprevisibilidade não é uma medida em si, mas qualificada pela urgência.

O abuso no uso dos créditos extraordinários tem suscitado o interesse da jurisprudência constitucional, chamada a se pronunciar sobre a inconstitucionalidade destas medidas provisórias. O controle de constitucionalidade dos requisitos dos créditos extraordinários não encontrou, senão recentemente, guarida no Supremo Tribunal Federal. Uma série de decisões negava a possibilidade deste controle, escorando-se em argumentos que reforçavam a execução orçamentária como competência exclusiva do Poder Executivo. Repetia-se que os atos orçamentários têm a natureza meramente de lei formal, de efeitos concretos e limitados, portadores de normas individuais (ADI 1.716/DF, rel. Min. Sepúlveda Pertence); que o requisito da previsibilidade não decorre objetivamente do ato atacado, isto é, do crédito extraordinário aberto por medida provisória, mas de outra lei - a lei orçamentária anual, cujo exame seria indispensável, mas impossível (ADI 1.496/DF, rel. Min. Moreira Alves); que a jurisprudência da corte já estava suficientemente consolidada no sentido das leis orçamentárias serem atos administrativos revestidos simplesmente da forma de lei (ADI 2.925/DF, rel. Min. Ellen Gracie); que o art. 21, $\S 1^{\circ}$, do Regimento Interno do Supremo Tribunal Federal diz ser impróprio o controle abstrato de constitucionalidade sobre matéria desprovida de generalidade, abstração e impessoalidade (ADI 3.487/DF, rel. Min. Ellen Gracie); e que não caberia ao STF, por obediência ao princípio da separação de poderes, aferir a substância mesma da despesa, o que é indispensável para verificar sua imprevisibilidade (ADI 3.709/DF, rel. Min. Celso Peluzo; ADI 3.712/DF, idem). 
A Corte experimentou, recentemente, uma alteração nestes paradigmas de controle de constitucionalidade de medidas provisórias e de matéria orçamentária. De início, na ADI 3.891/DF, cujo relator foi o ministro Ricardo Lewandowski, caminhavase à aplicação da jurisprudência da Casa, num caso em que a Medida Provisória n. ${ }^{\text {o } 364,}$ de 18 de abril de 2007, abriu crédito extraordinário em favor de diversos ministérios (Educação, Justiça, Transportes, Esportes, Integração Nacional e Cidades) no valor de R\$ 1.717.041.026,00, destinado ao apoio ao desenvolvimento da educação básica, complementação ao FUNDEF, obras de infraestrutura para os Jogos Pan-americanos de 2007, conservação de rodovias federais, construção da Ferrovia Norte-Sul, entre outros. Mais se assemelhava a um orçamento retificativo que a um crédito extraordinário, em razão da diversidade de seus objetivos. O Partido Popular Socialista (PPS), autor da ação, alegou inexistência do binômio urgência-imprevisibilidade, denunciando a falta de planejamento. Segundo o Min. Gilmar Mendes, a reiteração de decisões pretéritas do STF estava colocando a salvo do controle de constitucionalidade um sem-número de leis, o que provocava enorme insegurança jurídica. Afirmou, ainda, que não se discute a impossibilidade de que atos sem caráter de generalidade se submetam ao controle abstrato das normas, mas situação diversa é a de atos editados sob a forma de lei. A Constituição não fez distinção entre leis conformadas com ou sem o atributo da generalidade e da abstração. Assim, se o constituinte preferiu que determinados atos, ainda que de efeitos concretos, fossem submetidos à forma de lei, não cabe ao intérprete debilitar a garantia constitucional e isentar inúmeras leis do controle de constitucionalidade. Confirmou entendimento já exposto pela doutrina constitucional, e que se lê em Manoel Gonçalves Ferreira Filho ${ }^{239}$,

[a] lei ordinária é um ato legislativo típico. É um ato normativo primário. Em regra, edita normas gerais e abstratas, motivo por que, na lição usual, é conceituada em função da generalidade e da abstração. Não raro, porém, edita normas particulares, caso em que a doutrina tradicional a designa por lei formal, para sublinhar que lei propriamente dita só é aquela, a que tem matéria de lei, por isso chamada de "lei material". Essa distinção, contudo, não traz vantagens, além de não ser, muita vez, fácil de marcar. De fato, quanto ao momento de sua instauração e, sobretudo, quanto à eficácia (que é o mais importante), a lei dita material e a lei dita formal estão num só e mesmo plano.

\footnotetext{
${ }^{239}$ FERREIRA FILHO, Manoel Gonçalves. Do processo legislativo. $5^{\mathrm{a}}$. ed. São Paulo: Saraiva, 2002, p.
} 204. 
Não se pode deixar de dizer que o encaminhamento desta questão já encontrava eco na $\mathrm{ADI} 2.925$, anteriormente citada, em que não se acompanhou o voto da relatora, ministra Ellen Gracie. Aí, embora se afirmasse a impossibilidade do controle concentrado em normas de efeitos concretos, permitiu-se o controle da parte da Lei de Diretrizes Orçamentárias que contivesse dispositivo genérico. Com este caráter entendeu-se a regulação, prevista na LDO, dos limites para abertura de créditos suplementares previamente autorizados pela LOA, especificamente quanto ao remanejamento de recursos da CIDE-Combustíveis. Haveria, então, um desvio das finalidades traçadas pelo art. $177, \S 4^{\circ}$, da Constituição, para esta espécie tributária. No limite, a indenidade das margens de remanejamento ao controle de constitucionalidade estaria a permitir o afastamento das vinculações constitucionais de recursos públicos, livremente transitáveis dentro do orçamento.

Decisão paradigmática, ainda, foi proferida na ADI 4.048/DF, de relatoria do Min. Gilmar Mendes, proposta pelo Partido da Social Democracia Brasileira (PSDB), contra a Medida Provisória $n^{\circ} 405 / 07$, que abriu crédito extraordinário, em favor da Justiça Eleitoral e de diversos órgãos do Poder Executivo, no valor global de R\$ 5.455.677.660,00. Embora não seja um elemento juridicamente relevante para tornar admissível o controle de constitucionalidade, o crédito impressionava pelo volume, contribuindo para que aquele exercício de 2007 alcançasse o maior montante de recursos abertos por créditos extraordinários numa série de 10 anos (cf. Gráfico 1). Afirma o relator que o requisito da imprevisibilidade não se submete apenas ao juízo político, mas apresenta, na Constituição, feição de maior objetividade que os elementos de relevância e urgência, reconhecendo a tese da característica objetiva da imprevisibilidade. Da análise da exposição de motivos da Medida Provisória 405/2007, porém, não se depreende serem as despesas que se pretendem atender imprevisíveis e urgentes. Ainda que se reconheça a intenção de evitar situações de crise decorrentes dos problemas apontados, não se pode dizer que estas circunstâncias eram imprevisíveis. Ademais, em muitos dos casos, trata-se de requerer despesas para prevenir situações, o que indica, por si só, sua previsibilidade. Outro aspecto relevante, segundo o relator ${ }^{240}$, é que

[i]mpressiona a quantidade elevada de medidas provisórias editadas, no último ano, pelo Presidente da República, para abertura de créditos

${ }^{240}$ ADI - MC/DF, rel. Min. Gilmar Mendes, de 15/05/2008, p. 88. 
suplementares ou especiais travestidos de créditos extraordinários. Desde o início do ano de 2007, já se podem contar mais de 20 medidas provisórias destinadas à abertura de créditos de duvidosa natureza extraordinária.

A análise destas ações levadas ao STF e a nova orientação imprimida a tais casos pela Corte têm demonstrado que os requisitos constitucionais para a abertura de créditos extraordinários não são cumpridos e que a discriminação estabelecida entre créditos suplementares, especiais e extraordinários não tem assumido grande significação na prática, tomando-se um pelo outro de acordo com a conveniência e a ocasião. Não menos importante é que tais decisões mostraram que estes vícios podem ser arguidos em controle concentrado de constitucionalidade.

Outro aspecto a ser analisado a respeito dos créditos extraordinários é que, sendo eles próprios instrumentos de flexibilidade, são também passíveis de flexibilização pelo contingenciamento de recursos. Isto demonstra uma incongruência entre os diversos instrumentos de flexibilidade orçamentária: se o crédito extraordinário foi aberto para atender a uma despesa urgente, que sentido faz suspender sua execução? Nota-se que em alguns exercícios financeiros há uma cunha entre os créditos extraordinários previstos e sua quantia executada, notadamente a partir de 2004.

Percebe-se que o índice mais baixo de execução em determinados intervalos de tempo (de 2004 a 2008) traz ao menos duas delicadas questões. De um lado, é altamente questionável a obediência ao requisito da urgência para os créditos extraordinários, visto que os montantes previstos não foram gastos. De outro, podem-se supor deficiências do atual sistema de planejamento orçamentário, pois, sendo apenas em pequena parte executada, é duvidoso que a despesa fosse tão relevante que não pudesse esperar sua inclusão no orçamento do próximo ano. Estes dados quantitativos podem apontar para o descumprimento do requisito constitucional da imprevisibilidade - e o insuficiente controle que vem sendo exercido pelo Poder Legislativo a este respeito. 


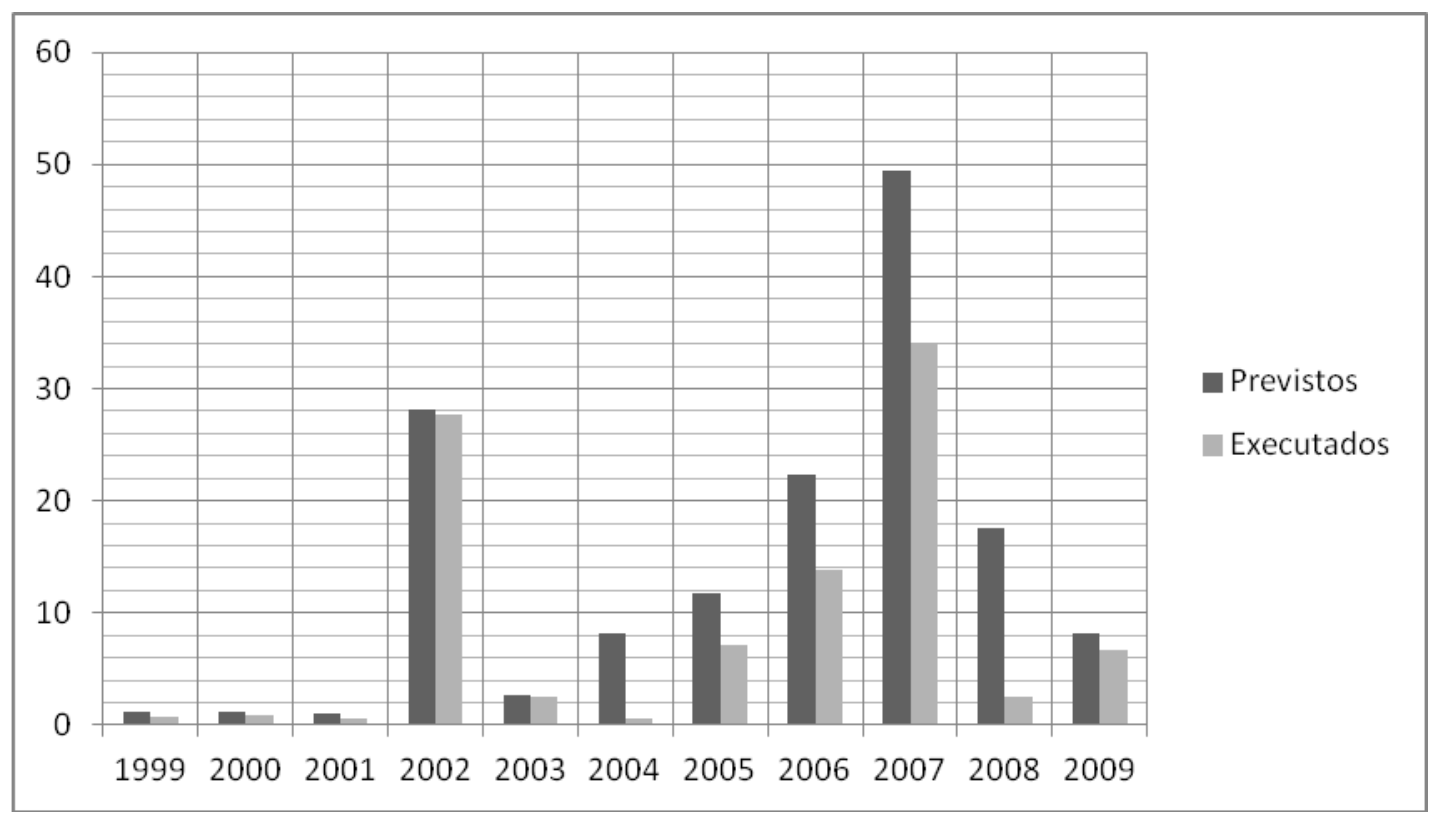

Figura 1 - Créditos Extraordinários Autorizados e Executados de 1999 a 2009

\subsubsection{Créditos suplementares autorizados na LOA}

O Parlamento tem fracas condições de participar da abertura de créditos extraordinários, pois isso é feito em momento posterior em que o gasto pode até mesmo já se ter efetuado. Torna-se prejudicial, portanto, a previsão de que este controle não seja prévio. Em outros casos de créditos adicionais, porém, o problema está em que a atuação do Poder Legislativo, além de não ser prévia, sequer é específica. Trata-se dos créditos suplementares cuja abertura é autorizada previamente na lei orçamentária anual, por decreto do Poder Executivo.

O comando do artigo $165, \S 8^{\circ}$, da Constituição, repetiu, sem alteração do texto, preceito que ininterruptamente tem feito parte das constituições brasileiras desde a Reforma Constitucional de 1926, que acrescentou $\S 1^{\circ}$ ao art. 34 da Constituição de 1891. Esta reforma destinava-se a eliminar as chamadas caudas orçamentárias, afirmando o princípio da exclusividade de modo a evitar que dispositivos sem conteúdo orçamentário fossem incluídos na lei de orçamento. Disso se extrai a existência de um conceito constitucional de matéria orçamentária: se isto for aquilo que pode constar da lei de orçamento, matéria orçamentária, no seu sentido constitucional, apenas pode ser a previsão de receitas e a fixação de despesa. A vedação, entretanto, não é absoluta, e o texto constitucional previu duas exceções: além da matéria orçamentária propriamente 
dita, a lei orçamentária poderá conter autorização prévia para a abertura de créditos suplementares, no jargão denominada de margem de remanejamento, e a autorização para contratação de operações de crédito. São duas exceções que, como visto, não inovam a tradição orçamentária brasileira: a previsão da autorização para abertura de créditos suplementares reaviva a velha Tabela B dos primeiros orçamentos brasileiros. Embora as atuais margens de remanejamento não contenham exatamente uma lista específica de serviços cujas dotações são suplementáveis, elas trazem hipóteses bastante detalhadas de sua utilização, apontando suas fontes de recursos e os limites percentuais remanejáveis de diferentes dotações. Pode-se dizer, assim, que a atual Seção III da lei de orçamento substitui a tão atacada e debatida Tabela B, com algumas diferenças.

O propósito da reforma de 1926 tinha um propósito, porém, específico: que os créditos suplementares previamente autorizados se destinassem apenas às despesas variáveis, que não puderam ser exatamente quantificadas. Sua finalidade seria somente autorizar que serviços passíveis de estimação aproximativa não necessitassem de autorizações legislativas para cada caso, e o governo poderia atender às diferenças transferindo recursos dentro do próprio orçamento. Pontes de Miranda, ao comentar dispositivo idêntico da Constituição de 1934, manifestou-se favoravelmente a tais margens por esta razão: eram medidas afins "às verbas orçamentárias e à economia dos orçamentos". Ressalvou, entretanto, que "[t]udo aconselha que, no caso dos créditos suplementares, se determinem de antemão os serviços para os quais podem ser abertos e a quanto podem montar de per si e em quais condições." ${ }^{241}$, reforçando a necessidade de alguma tipificação para evitar abusos da parte do Poder Executivo.

A prática tem se sofisticado nas sucessivas leis orçamentárias federais e se tornado um poderoso instrumento para alterar a lei orçamentária. É também na prática que se tem colocado tal instrumento à disposição do governo. Esta sofisticação decorre do detalhamento cada vez maior das hipóteses em que a administração pública federal pode utilizar-se dos recursos previstos para a abertura de créditos suplementares para atender às hipóteses previstas para esta modalidade, que seriam aquelas provenientes da necessidade de reforço da dotação prevista.

\footnotetext{
${ }^{241}$ PONTES DE MIRANDA. Comentários à Constituição da República dos Estados Unidos do Brasil. Rio de Janeiro: ed. Guanabara, 1936. Tomo 1, p. 547-8.
} 
A importância de tais margens de remanejamento para a gestão orçamentária pode ser indicada pela atenção cada vez maior que as leis orçamentárias dão ao assunto, criando cada vez mais hipóteses de sua aplicação e reforçando a plena institucionalização do procedimento na prática política orçamentária. Habitualmente fixada em 10\% do valor de cada subtítulo, o orçamento de 2011 foi pródigo em expandir a abrangência da autorização, que passou a ser de $25 \%$ para investimentos (art. $4^{\circ}$, II, da Lei 12.381, de 9 de fevereiro de 2011), o que é abertamente medida destinada a conferir maior maleabilidade à gestão do Plano de Aceleração do Crescimento (PAC). O percentual proposto pelo governo era ainda maior, de 30\%, mas as negociações para aprovação deste orçamento o reduziram. ${ }^{242}$ Pelo caput do art. $4^{\circ}$ da lei orçamentária para 2011, não é difícil antever um dos itens desta pauta de negociação entre parlamentares e governo, pois ficaram expressamente excluídos da margem de remanejamento os recursos destinados ao atendimento de emendas parlamentares individuais e coletivas.

Esta situação denota as deficiências do sistema de planejamento, que fazem ser interesse estratégico da Administração Pública incluir espaços de livre disposição no orçamento, os quais chegam a um quarto das verbas de investimentos no caso federal. De outra parte, demonstra também que a atuação política parlamentar tende a ignorar as questões públicas gerais de planejamento e políticas públicas, atendo-se ao que efetivamente lhe interessa: a aprovação de emendas que lhe tragam as vantagens político-eleitorais que a discussão abstrata sobre programas de governo e condições macro-estruturais do país não traz.

A situação pareceria menos grave não houvesse países nos quais a execução orçamentária tem sido inegavelmente entregue apenas ao Executivo numa intensidade ainda mais forte que a brasileira. $\mathrm{Na}$ Argentina, a margem de remanejamento orçamentária constitui instrumento tão usual que, para sua utilização, não é sequer necessário decreto presidencial. Neste país, tem-se operado um processo de delegação das competências orçamentárias do próprio chefe do Executivo para outros órgãos

\footnotetext{
${ }^{242}$ Informações divulgadas pelo órgão oficial de comunicação do Senado Federal dão conta de que o acordo partidário que permitiu a aprovação do referido orçamento teve como um dos pontos de negociação a redução desta margem de remanejamento ("Orçamento assegura ao governo flexibilidade para usar verba do PAC". Jornal do Senado, Brasília, 23 de dezembro de 2010, p. 3).
} 
administrativos e é suficiente ato do chefe do gabinete de ministros para modificar dotações orçamentárias ${ }^{243}$.

Chama a atenção, também, que a competência para autorizar genérica e anteriormente a abertura de créditos suplementares é do Poder Legislativo, mas os termos desta autorização já vêm colocados pelo Executivo - que tem determinado o modo de exercício da competência privativa de outro Poder. Embora o mesmo ocorra quanto às leis orçamentárias, não se pode esquecer que a margem de remanejamento é um acréscimo ao orçamento, uma "cauda". Como tal, não contém previsão de receita nem fixa despesa, não sendo, por isso, matéria orçamentária. É, antes, uma autorização para modificar o orçamento, que adere à LOA como um rabilongo, um rider, Bepackung ou cavalier budgetaire, tais como denominados em outros sistemas.

A posição proeminente do Poder Legislativo no quadro da separação da funções orçamentárias, contudo, leva a questionar, novamente, a forma como lhe cabe participar da execução orçamentária na hipótese aqui considerada. Pois compondo apenas formalmente a lei orçamentária, visto que não prevê receitas nem fixa despesas, trata-se tão somente de um acréscimo cuja inclusão naquela lei a Constituição autorizou, por razões de celeridade e de uma certa aproximação de conteúdo. Se pode estar ali incluída (e claro está tratar-se de uma permissão, e não de um dever), nada impede que não esteja. E no caso de se optar por veicular tais margens de remanejamento por outra espécie normativa que não a lei orçamentária, cabe indagar qual seria ela.

Sinteticamente, trata-se de uma autorização prevista em lei para que esta mesma lei possa ser alterada por decreto. Ocorre uma autorização genérica do Poder Legislativo ao Executivo para que este regule situações orçamentárias específicas de utilização de recursos para fins diversos daqueles aprovados, por ato próprio e sem consulta ao Congresso. Não se coloca possível, porém, dizer que se trata de um caso de delegação constitucionalmente autorizada (por norma constitucional originária) de competência legislativa, como propôs o ministro Nelson Jobim, obiter dictum, na discussão da ADI 2925-8/DF. ${ }^{244}$ A única hipótese expressamente prevista para delegação de competência

\footnotetext{
243 ARGENTINA. Ministerio de Economía y Finanzas Públicas. El Sistema Presupuestario en la Administración Nacional de la República Argentina. Buenos Aires: Gobierno Federal, 2008, p. 150.

${ }^{244}$ Cf. STF. ADI 2925-8/DF. Relator: Min. Ellen Gracie. Julgamento em: 11/12/2003, publicado no DJ em 04/03/2005, p. 157. Acessado em 12/02/2012. Disponível em http://redir.stf.jus.br/paginadorpub/paginador.jsp?docTP=AC\&docID=266953
} 
legislativa é a das leis delegadas, de raro uso na prática constitucional brasileira. Da mesma forma, seu procedimento é significativamente diverso daquele previsto para as margens de remanejamento. Conforme estatui o art. 68 da Constituição, a delegação é solicitada pelo Presidente da República ao Congresso, que a outorga por meio de resolução que especifica seu conteúdo e os termos de seu exercício. Os créditos suplementares previstos na margem de remanejamento são abertos, por sua vez, não por lei delegada, mas por decreto do Presidente da República. É patente a inadequação de enquadrar as autorizações prévias de abertura de créditos suplementares como hipótese de delegação legislativa, prevista pelas normas constitucionais que regulam o processo legislativo federal.

Cabe, em primeiro lugar, indagar da competência para autorizar previamente a abertura de créditos suplementares. Esta só pode ser do Poder Legislativo, do contrário sequer necessitariam ser previstas na lei de orçamento: bastaria ato do chefe do Poder Executivo. Seria, neste sentido, um contra-senso que o Presidente da República, no caso federal, necessitasse autorizar a si próprio. Logicamente, portanto, trata-se de competência parlamentar. Mais do que isso, tem-se que tal autorização constitui competência exclusiva do Poder Legislativo, que não a poderia delegar a outro Poder sob pena de renunciar a suas prerrogativas constitucionais. Sua veiculação se pode dar, portanto, por meio de decreto legislativo, pois é esta a espécie normativa destinada a veicular matéria de competência exclusivamente parlamentar. Embora os temas a ele sujeitos estejam basicamente previstos no art. 49 da Constituição, este rol não é exaustivo.

A lei orçamentária frequentemente contém, assim, matéria de decreto legislativo jungida a outros preceitos orçamentários, aderindo à lei e seguindo seu procedimento, como verdadeira "cauda orçamentária". Isto implica que eventual veto aposto pelo Presidente da República ao orçamento não se estende também à margem de remanejamento, pois não há participação do Executivo na edição de decretos legislativos. Estes se incluem no orçamento não como dispositivo orçamentário, mas como acessório àquela lei. É o que já percebeu Aureliano Leal, talvez um dos poucos constitucionalistas a se dedicar mais profundamente ao tema, a respeito de dispositivo idêntico da Constituição de 1891, a ela adicionado em 1926. Ao discorrer sobre a natureza jurídica da lei de orçamento, observou que ela continha diversos dispositivos 
de conteúdo material (entenda-se, com sentido de lei material), dentre os quais este de conteúdo não orçamentário: a autorização prévia para a abertura de créditos suplementares. E, por se tratar de competência exclusiva do Congresso autorizá-la, "a autorização para abrir créditos suplementares também não pode deixar de ser considerada um decreto legislativo."245

Uma conseqüência importante desta ideia para as negociações entre o governo e parlamento, além de reforçar a extensão das competências parlamentares na fase de execução orçamentária, é que as dificuldades para atingir um acordo sobre os limites da margem de remanejamento não devem, necessariamente, impedir a aprovação da lei orçamentária em si, permitindo evitar o prejuízo de uma lei orçamentária tardia. A solução é destacar a Seção de seu texto referente a tais autorizações, que podem ser concedidas posteriormente por decreto legislativo, pois esta é seu veículo próprio.

O problema da qualificação jurídica da margem de remanejamento não esgota, porém, a discussão sobre a necessidade de sua permanência no sistema constitucional orçamentário. Hipótese rara de encontrar no direito orçamentário comparado, a autorização prévia para ampla suplementação de receitas é exceção ao princípio da especificação (à medida em que se autoriza a transferência de recursos entre programas sem autorização legislativa específica) que compromete o controle parlamentar e confere poucos incentivos ao planejamento da ação governamental. Isto é feito sem que muitas vezes se dê conta de outras possibilidades interpretativas presentes no texto constitucional, decorrentes de uma sistemática apreciação das possibilidades de participação parlamentar na execução do orçamento.

\subsection{Controle parlamentar fraquíssimo: limitação de empenho e} movimentação financeira

A Lei de Responsabilidade Fiscal (Lei Complementar n. ${ }^{\circ}$ 101/2000) atribuiu novas funções à Lei de Diretrizes Orçamentárias, dentre as quais a necessidade de que ela confira parâmetros à programação financeira e ao cronograma de execução mensal de desembolso. Isto é previsto em seu artigo $8^{\circ}$.

\footnotetext{
${ }^{245}$ LEAL, Aureliano. Theoria e Prática da Constituição Federal Brasileira. Rio de Janeiro: F. Briguiet e
} Cia. Editores, 1925, p. 501. 
Esta programação é instrumento de planejamento, como já visto, por meio da qual se ajusta o ritmo de execução orçamentária ao fluxo de recursos financeiros disponíveis. Compete-lhe permitir a liberação de recursos aos programas orçamentários. Para tanto, o cronograma opera de acordo com as metas do Anexo de Metas Fiscais, outra inovação trazida pela Lei de Responsabilidade Fiscal e incorporada à Lei de Diretrizes Orçamentárias $\left(\operatorname{art.} 9^{\circ}\right.$ ). A medida tem o objetivo claro de vincular a Administração a maior controle sobre os gastos públicos, indicando tanto o equilíbrio orçamentário como a transparência dos compromissos governamentais com a dívida pública. $^{246}$

O monitoramento do cumprimento das metas fiscais primárias e nominais previstas no Anexo de Metas Fiscais é feito de forma contínua, durante todo o processo de execução orçamentária. O cálculo das Necessidades de Financiamento do Governo Central (NFGC) serve como referência para evidenciar a trajetória das receitas e das despesas. Os fatos supervenientes que impliquem alteração nas alocações orçamentárias têm repercussão sobre todo o processo de execução, tornando necessária a revisão dos limites orçamentários e da programação financeira.

Diante de limitações ao poder de gastar, o governo deixa de executar parte do orçamento, promovendo o chamado contingenciamento das despesas empenhadas. Cabe ao chefe de cada Poder publicar ato que contenha o montante indisponível, estabelecendo quanto seus órgãos terão como limite de movimentação financeira e empenho, nos termos do art. $9^{\circ}$. O Poder Executivo também comunicará estes limites aos Poderes Legislativo e Judiciário e ao Ministério Público. $\mathrm{O} \$ 3^{\circ}$ do citado artigo estatui que, no caso destas três esferas não promoverem a limitação no prazo estabelecido, o Poder Executivo fica autorizado a limitar os valores financeiros segundo os critérios fixados pela LDO.

Como a finalidade da limitação de empenho é ajustar o ritmo de execução da despesa à arrecadação, assim que for restabelecida a receita prevista, mesmo que de maneira parcial, as dotações contingenciadas devem ser recompostas proporcionalmente àquilo que foi reduzido em face dos critérios estabelecidos pela LDO.

\footnotetext{
246 BRASIL. Ministério do Planejamento. Manual Técnico Orçamentário para 2011 (MTO 2011). Brasília: Governo Federal, 2011, p. 83.
} 
Algumas despesas, porém, não se submetem a estas regras. São aquelas que configuram obrigações legais e constitucionais de responsabilidade dos entes federativos, assim como aquelas destinadas ao pagamento do serviço da dívida pública e outras expressamente ressalvadas na lei de diretrizes, conforme a opção do legislador.

Nota-se que este quadro normativo prevê a limitação de empenho como recurso para não comprometer a política fiscal e garantir a formação de superávit primário ou nominal, cumprindo os objetivos do Anexo de Metas Fiscais. O deferimento do pagamento da despesa, porém, está longe de cumprir apenas estes objetivos.

Esta disciplina normativa poderia vir a indicar que a Lei de Responsabilidade Fiscal expandiu as possibilidades de que o Executivo contingencia recursos - tanto mais que estabeleceu até mesmo a possibilidade de limitação de empenho realizado por outros poderes. As possibilidades ainda são amplas, mas algo parece indicar que a referida lei, ao tratar do assunto, acabou por reprimir, e não por expandir, as possibilidades de que o Poder Executivo lance mão deste recurso.

Antes da previsão normativa, a decisão governamental de não gastar se fundamentava, evidentemente, no caráter autorizador da lei de orçamento. Como o orçamento estabelece tetos, e executar a despesa é uma decisão administrativa tomada apenas e tão somente pelo governo, deixar de realizar despesas não obrigatórias não constituía senão uma faculdade inerente aos poderes do Executivo. Se o Executivo se visse na iminência de realizar determinada política fiscal restritiva dos gastos, bastavalhe bloquear a liberação dos recursos com fundamento nestas prerrogativas. O que a Lei de Responsabilidade Fiscal fez, porém, foi introduzir o dever de promover a limitação de empenho conforme a programação da execução financeira, referindo-se apenas a esta possibilidade. Negados tais poderes governamentais imanentes, a limitação de empenho afigura-se impossível fora dos casos de ajuste fiscal, porque não expressamente autorizada, na atual sistemática legal.

Sempre se poderia argumentar, a este respeito, que tal restrição comprometeria o interesse público, por inviabilizar a necessária agilidade da parte do Executivo para responder a pressões contingentes do ambiente econômico. Confrontado com passivos contingentes, porém, nada impede que o governo adote as medidas necessárias para conter gastos: isto é o que lhe impõe a Lei de Responsabilidade Fiscal. O que não se 
justifica, porém, é a decisão imotivada de deixar de cumprir os objetivos orçamentários sem que se tenha evidenciado algum risco à estabilidade econômica.

A questão que se depreende, então, é: a quem tal necessidade deve ser evidenciada? A qual crivo deve ser submetido a decisão do Executivo? Parece que exatamente ao Poder Legislativo, que aprovou não apenas a lei orçamentária, mas também a Lei de Diretrizes Orçamentárias e os Anexos nela contidos. Não obstante, este controle fica reduzido a quase nada se tudo que o Poder Legislativo pode fazer é esperar o relatório da execução orçamentária para averiguar a decisão tomada pelo Poder Executivo. Em razão desta dificuldade, são diversas as propostas que vêm abrigadas no rótulo do "orçamento impositivo".

\subsubsection{Novamente dois casos: Alemanha e Estados Unidos da América}

A possibilidade de que o Parlamento participe de decisões na fase de execução orçamentária não é, de modo algum, desconhecida, e se observa tanto em sistemas parlamentaristas como presidencialistas. O notável é que se trata de provisão encontrada em regimes orçamentários tão diversos como aqueles da Alemanha e dos Estados Unidos da América, em que por tantas vezes se observou a defesa mais consolidada das prerrogativas governamentais na execução orçamentária, ainda que estas formas de participação se apresentem com significativas distinções.

É comum que em orçamentos alemães se encontre o seguinte dispositivo em diversas dotações: "[a] anulação do bloqueio requer o consentimento da Comissão de Orçamento do Parlamento Alemão"247. Se, na lei de orçamento enviada pelo governo, algumas das despesas foram anotadas como suspensas (Spervermerke), em alguns casos qualificados na própria lei é necessário o consentimento da Comissão de Orçamento do Parlamento para seu desbloqueio. $O$ mecanismo se denomina contingenciamento qualificado (qualifizierte Sperrvermerke). Em outros casos, ainda, é preciso que haja duplo consentimento, tanto da Comissão de Orçamento como de outro

\footnotetext{
247 "Die Aufhebung der Sperre bedarf der Einwilligung des Haushaltsausschusses des Deutschen Bundestages" (cf. ALEMANHA. Entwurf eines Gesetzes über die Feststellung des Bundeshaushaltsplanes für das Haushaltsjahr 2011. Dispõe sobre o orçamento do exercício de 2011).
} 
comitê técnico parlamentar (doppelt qualifizierte Sperrvermerke). ${ }^{248} \mathrm{O}$ contingencimanto qualificado (e também o duplamente qualificado) conduz a que o Executivo, antes da liberação de recursos consentida pela Comissão de Orçamento, tenha que obter seu parecer e negociar politicamente. Tem-se, então, que um comitê parlamentar deve amparar decisões governamentais técnicas, o que faz cair por terra o argumento puramente formal de que, como o orçamento constitui uma autorização, a decisão de gastar ou não gastar pertence à livre disposição do Executivo. ${ }^{249}$ Cabe, deste modo, à própria lei orçamentária definir quais as despesas que, por determinadas razões, não poderão ser conduzidas ou cuja execução não é obrigatória, especificando os casos em que se exigirá autorização de um ou mais comitês parlamentares para o levantamento da suspensão. ${ }^{250}$

Há, também, instituto semelhante ao da limitação de empenho brasileira: o contingenciamento por razões econômicas (hauswirtschaftliche Sperre) ${ }^{251}$, segundo o qual, se o comportamento das receitas ou das despesas assim o exigirem, cabe ao Ministério das Finanças, com o consentimento do ministro competente pela despesa, definir se o gasto pode ser executado. A Lei de Estabilidade, em vigor desde 1967, ainda define outra forma de bloqueio de recursos, de caráter conjuntural, para situações de aumento na demanda proveniente de superaquecimento econômico. Esta circunstância permite que o Ministro das Finanças, com autorização do governo, tenha livre disposição sobre alguns recursos previstos no orçamento, o que quer dizer, especialmente, que o início de obras e a inclusão de futuras despesas obrigatórias em orçamentos seguintes dependam de seu consentimento. ${ }^{252}$ Embora, neste caso, não se preveja a necessidade de autorização parlamentar, a prática estabeleceu que estes contingenciamentos político-conjunturais devem ser autorizados pela Comissão de Orçamento. $^{253}$

\footnotetext{
${ }^{248}$ Cf. MANDELARTZ, H. Das Zusammenwirken von Parlament und Regierung beim Haushaltsvollzug: ein Beitrag zum parlamentarischen Regierungssystem der Bundesrepublick Deutschland. Frankfurt a.M.: Peter D. Lang, 1980, p. 32-3.

${ }^{249}$ MANDELARTZ, H. Das Zusammenwirken von Parlament und Regierung beim Haushaltsvollzug: ein Beitrag zum parlamentarischen Regierungssystem der Bundesrepublick Deutschland. Frankfurt a.M.: Peter D. Lang, 1980, p. 34.

${ }_{250} \S 22$ BHO (Bundeshaushaltsordnung).

${ }^{251} \S 41$ BHO.

$252 \S 1$ StabG (Stabilitätsgesetz)

${ }^{253}$ MANDELARTZ, H. Das Zusammenwirken von Parlament und Regierung beim Haushaltsvollzug: ein Beitrag zum parlamentarischen Regierungssystem der Bundesrepublick Deutschland. Frankfurt a.M.: Peter D. Lang, 1980, p. 36.
} 
Finalmente, preveem-se também outras possibilidades de suspensão do gasto para obras em que as fundações ainda não foram concluídas. Interessante notar que, também nestes casos, a legislação faz referência apenas ao necessário consentimento do Ministro das Finanças. Não obstante, a atuação da comissão parlamentar de orçamento tem sido mantida. ${ }^{254}$

Há fundamentações diversas para a previsão normativa de que o Parlamento, ainda que já tenha aprovado o orçamento, entenda que esta autorização não foi suficiente e é necessário que se manifeste novamente. A opinião esposada por Kewenig, de que o contingenciamento qualificado é previsto para os casos de relevantes implicações políticas, indica indubitavelmente um fator relevante. ${ }^{255}$ Entretanto, importante também é o fator temporal. Muitas decisões relativas ao orçamento precisam ser tomadas em curto espaço de tempo. O projeto de orçamento precisa ser aprovado com relativa urgência, e decide-se postergar a discussão sobre determinadas dotações, levando-a a um momento futuro em que o orçamento já está aprovado e vigente para outras matérias relevantes. O Parlamento pode, então, discutir com mais calma casos específicos de despesas, e para isso se prevê o contingenciamento qualificado. ${ }^{256} \mathrm{~A}$ aprovação orçamentária não significa, por si só, um laissez dépenser generosamente concedido ao governo, à medida que as matérias não completamente debatidas pela pressão do tempo têm sua discussão transferida para depois, marcando-se, assim, gastos que ainda merecem atenção e debate. O sistema parece bastante interessante em situações nas quais os parlamentares discutem efetivamente todas as políticas orçamentárias, e não apenas a parte relativa aos gastos para suas zonas eleitorais, ao mesmo tempo em que se preocupam com a viabilidade da política econômica ao não atrasar a entrada em vigor do orçamento em razão de dúvidas sobre dotações específicas. O contingenciamento é, portanto, uma decisão parlamentar, e a divisão do ciclo orçamentário em duas fases para o Poder Executivo e duas fases para o Poder Legislativo se mostra de pouco valor elucidativo.

\footnotetext{
${ }^{254} \S 24$ Abs. 3 Satz 3 BHO.

255 KEWENIG, W. Staatsrechtliche Probleme parlamentarischer Mitregierung am Beispiel der Arbeit der Bundestagsausschüsse. Bad Homburg v.d.H.: Gehlen, 1970, p. 35.

${ }^{256}$ MANDELARTZ, H. Das Zusammenwirken von Parlament und Regierung beim Haushaltsvollzug: ein Beitrag zum parlamentarischen Regierungssystem der Bundesrepublick Deutschland. Frankfurt a.M.: Peter D. Lang, 1980, p. 37.
} 
O caso alemão indica a participação parlamentar na fase de execução orçamentária por meio da necessidade específica de que consinta, prévia e especificamente, com o pagamento de algumas despesas já depois do orçamento aprovado. O fato de o governo decorrer do Parlamento, e, portanto, a execução orçamentária ser, no limite, o exercício de uma competência conferida pelo Poder Legislativo, poderia indicar que essa forma de participação parlamentar na execução seria própria de sistemas parlamentaristas. O caso dos Estados Unidos da América, paradigma de sistema presidencialista, o desmente: mesmo a força da tradição do orçamento do Executivo culminou, após o governo Nixon, na necessidade de que o Congresso aprove mesmo a decisão de não gastar. Isto é, a decisão de executar uma despesa abaixo do teto orçamentário.

Se o Presidente dos Estados Unidos da América decide gastar menos do que foi aprovado pelo Congresso para uma despesa específica, há dois caminhos a seguir: ou estes gastos são cancelados ou atrasados. Tais ações, denominadas impoundments e que se assemelham aos contingenciamentos, eram tipicamente uma maneira de expressar a insatisfação presidencial com o trabalho do Legislativo ${ }^{257}$. Isto mudou desde o Control Act de 1974, quando Presidente e Congresso passaram a ter atribuições conjuntas na decisão de não gastar.

O contingenciamento orçamentário, nos Estados Unidos, representava um modo de contenção de recursos, nas situações em que não fosse necessário gastar todo o volume de recursos previstos para determinada finalidade. Traduzia uma prática com a economia de recursos e a eficiência do gasto. Esta tradição, que tinha o significado profundo de um acordo tácito entre Executivo e Legislativo a propósito da inutilidade de se ter de recorrer a um moroso processo legislativo para tomar uma decisão positiva para as finanças públicas, começou a ser alterada durante o governo Nixon. Este presidente tentou mudar esta tradição de entendimentos informais, esforçando-se por inserir o contingenciamento no campo de prerrogativas presidenciais, que poderia gastar

\footnotetext{
${ }^{257}$ WLEZIEN, C. The Politics of Impoundments. Political Research Quarterly, v. 47, n. 1, mar. 1994, p. 59.
} 
somente onde quisesse. ${ }^{258}$ Procedeu-se, a partir de então, a um massivo bloqueio de recursos. Schick ${ }^{259}$ formula-o com clareza:

[1]onge de ser uma rotina administrativa, os contingenciamentos no final de 1972 e 1973 foram concebidos para reescrever a política nacional às custas dos poderes e intentos parlamentares. Em vez de postergar despesas, o objetivo de Nixon era o cancelamento de programas indesejados. (...) Quando Nixon realizou contingenciamentos por objetivos políticos, ele, na verdade, disse ao Congresso: "Eu não me importo com as suas dotações; Eu decidirei o que será gasto".

Wildavsky e Caiden analisam que nenhum outro presidente havia tão diretamente ignorado as competências parlamentares sobre o orçamento, a não ser em casos emergenciais de guerra. Formularam, então, aquelas que parecem ser as mais decisivas questões sobre a execução orçamentária em qualquer sistema ou regime de governo: se o chefe do governo pode passar impune depois de contingenciamentos massivos, o que ele não pode fazer? Se o power of the purse for tão abertamente desafiado, o que sobra para o Congresso? ${ }^{260}$

Nos Estados Unidos da América, as prerrogativas parlamentares sobre o orçamento tiveram que ser tão defendidas em 1974 como o foram em 1774. Mas pela razão oposta: duzentos anos antes, o Congresso conquistara suas competências orçamentárias para se contrapor às ameaças de um Executivo que poderia gastar demais. O desafio contemporâneo, porém, se tornou criar condições de contrabalançar o poder de um chefe de governo que quer gastar pouco e que desafia o Poder Legislativo (ou, como diriam os próprios parlamentares, o povo por ele representado). Os remédios, portanto, teriam que ser diferentes. A ênfase passaria a ser dada nos instrumentos parlamentares de participação na execução do orçamento, e não apenas na fase de elaboração, o que criou uma nova divisão de funções no ciclo orçamentário. $O$ instrumento de tal alteração foi o Congressional Budget and Impoundment Act de 1974, que seguiu a tradição política americana de fazer uma espécie de "bricolagem"

${ }^{258}$ WILDAVSKY, Aaron; CAIDEN, Naomi. The New Politics of the Budgetary Process. $5^{\mathrm{a}}$ ed. New York: Pearson Longman, 2004, p. 74.

${ }^{259}$ SCHICK, A. Congress and Money. Washington D.C.: The Urban Institute, 1980, p. 46-8. No original: "[f]ar from administrative routine, Nixon's impoudments in late 1972 and 1973 were designed to rewrite national policy at the expense of congressional power and intent. Rather than the deferment of expenses, Nixon's aim was the cancellation of unwanted programs. (...) When Nixon impounded for policy reasons, He in effect told Congress, 'I don't care what you appropriate; I will decide what will be spent."'

${ }^{260}$ WILDAVSKY, Aaron; CAIDEN, Naomi. The New Politics of the Budgetary Process. $5^{\mathrm{a}}$ ed. New York: Pearson Longman, 2004, p. 74. 
institucional, acrescentando novos procedimentos e instituições, reinterpretando as anteriores.

A formalização dos contingenciamentos presidenciais passou a depender de algumas etapas. Caso não deseje gastar o total dos fundos previstos para determinada despesa, o Presidente necessita propor ao Congresso a rescisão da dotação (rescission). Se, ao contrário, quiser apenas atrasar o gasto, deveria propor seu diferimento (deferral). O Congresso deve aprovar a proposta de rescisão em até 45 dias. Se não o fizer, a proposta é considerada rejeitada - isto é, o dinheiro deve ser gasto como previsto no orçamento. $\mathrm{O}$ diferimento, a seu turno, tem efeitos automáticos a partir da decisão presidencial, mas não pode ultrapassar o exercício fiscal. A despeito disso, a qualquer tempo qualquer uma das casas parlamentares poderia rejeitá-lo em votação específica de desaprovação. Se o Presidente não reportar ao Congresso que não gastou o total dos recursos, o controlador-geral (chefe do General Accounting Office) deverá avisar o Parlamento. A comunicação do controlador-geral tem o mesmo efeito jurídico da proposta presidencial de rescisão ou diferimento. Se o Presidente ignora a rejeição parlamentar, o controlador-geral é legitimado a propor uma ação civil judicial. É claro que sempre fica à disposição do Presidente a opção de provocar uma crise constitucional, o que é, no entanto, improvável. ${ }^{261}$

Estas formas de participação parlamentar na execução orçamentária norteamericana têm sido especuladas, constantemente, como o réquiem do orçamento do Executivo: uma ideia ambígua exatamente em razão das dúvidas sobre a obrigatoriedade de gastar os montantes previstos no orçamento. Havia certa vagueza a respeito da posição do Presidente como chefe do Executivo no sistema norte-americano de separação de poderes. ${ }^{262}$ Até o governo Nixon, o sistema havia servido, mas a contraposição frontal deste às competências parlamentares expôs todas as ambiguidades da relação entre administração pública e agenda política. A polarização entre um presidente republicano e um parlamento democrata rompeu a política de acomodação que havia a respeito dos gastos públicos. A fragilidade das concepções orçamentárias de

\footnotetext{
${ }^{261}$ Cf. WILDAVSKY, Aaron; CAIDEN, Naomi. The New Politics of the Budgetary Process. $5^{\mathrm{a}}$ ed. New York: Pearson Longman, 2004, p. 75.

${ }^{262}$ CAIDEN, N. Paradox, Ambiguity, and Enigma: the Strange Case of the Executive Budget and the United States Constitution. In: RUBIN, I. (ed.). Public Budgeting: policy, process and politics. New York: ASPA Classis, 2008, p. 51
} 
1921, com um Congresso atuante, começou a ser exposta. ${ }^{263}$ Como bem destaca Pitsvada $^{264}$,

[p]residentes e congressos normalmente têm visões diferentes sobre as necessidades nacionais corporificadas nos programas e prioridades orçamentárias. Ambas as visões são legítimas e devem ser resolvidas mediante processo político em que o poder político conte mais que questões de eficiência administrativa.

Ficou perceptível que o contingenciamento de recursos como ato unilateral não ofereceu um procedimento nítido para resolver os impasses orçamentários entre os dois poderes, mas, ao contrário, incitou à sua paralisação e protraimento. ${ }^{265} \mathrm{~A}$ insuficiência do orçamento do Executivo como modelo de relações orçamentárias entre governo e parlamento pode ser destacada na sua inaptidão para solucionar os conflitos entre visões políticas divergentes.

\subsubsection{O orçamento impositivo e a revisão das relações de poder}

No caso brasileiro, as competências orçamentárias do Presidente da República têm sido interpretadas, tradicionalmente, de maneira bastante ampla. Sob a orientação predominante de que o orçamento é uma autorização de gasto conferida irrevogavelmente no momento em que o Parlamento o aprova, a execução orçamentária poderia bem ser compreendida como uma atividade em que gastar ou não gastar faz parte das prerrogativas governamentais.

Nota-se, porém, uma certa tendência: sucessivas propostas de emenda à Constituição e de alteração legislativa têm sido feitas para conferir ao Poder Legislativo instrumentos técnicos adequados para participar da decisão executória do orçamento. Seu produto é comumente denominado orçamento impositivo, ou um orçamento cujos montantes são de execução obrigatória. Com tais idéias, que não são uniformes e

\footnotetext{
263 CAIDEN, N. Paradox, Ambiguity, and Enigma: the Strange Case of the Executive Budget and the United States Constitution. In: RUBIN, I. (ed.). Public Budgeting: policy, process and politics. New York: ASPA Classis, 2008, p. 51.

${ }^{264}$ PITSVADA, B. T. The Executive Budget: an idea whose time has passed. In RUBIN, I. (ed.). Public Budgeting: policy, process and politics. New York: ASPA Classis, 2008, p. 66. No original: "Presidents and Congresses often have differing views on national needs as embodied in budgetary programs and priorities. Both views are legitimate and must be resolved through the political process where political power counts more than questions of administrative efficiency."

${ }^{265}$ SCHICK, A. Congress and Money. Washington D.C.: The Urban Institute, 1980, p. 48.
} 
apresentam variações, não se pretende, evidentemente, excluir a atividade administrativa de execução da despesa do campo material de atividades do Poder Executivo, mas possibilitar ao parlamento maiores condições de determinar o poder que tem o governo de alterar uma política por ele decidida. A atividade administrativa governamental fica, deste modo, preservada, pois o que se observa nessas tentativas não é mais que dar maior eficácia à já muito bem conhecida subordinação da administração à política e à lei. Dar maior eficácia à decisão política parlamentar, portanto.

A Lei de Responsabilidade Fiscal, ao estabelecer a necessária adequação do gasto às metas fiscais, já criou uma forma de orçamento impositivo, pois a suspensão da despesa fica condicionada a uma única hipótese. Não obstante, esta interpretação deixa de prevalecer diante das facilidades com que se utiliza o contingenciamento de recursos como instrumento de negociação. Em vista deste quadro, formularam-se diversas proposições para alterar a disciplina constitucional e legal do assunto.

Recebeu bastante destaque a Proposta de Emenda à Constituição (PEC) n. ${ }^{\circ}$ 22/2000, de autoria do senador Antônio Carlos Magalhães, aprovada pelo Senado e encaminhada à Câmara como a PEC n. ${ }^{\circ}$ 565/2006. A ela será dado maior destaque, mas antes deve ser mencionado o conteúdo de outras iniciativas.

Partindo da Câmara, a PEC 313/2000, de autoria do deputado Clementino Coelho, propôs a execução obrigatória das emendas parlamentares destinadas à saúde e à educação. Atualmente, encontra-se arquivada. No ano de 2001, foram duas as propostas de emenda constitucional: 421/2001 (dep. Miro Teixeira) e 481/2001 (dep. Wellington Dias), as quais, respectivamente, propunham incluir na Constituição dispositivo que tornaria o orçamento de execução obrigatória, a não ser quando o Congresso aprovasse solicitação presidencial para não gastar, e impedir que se suspendessem recursos destinados a emendas parlamentares. Por sua vez, a PEC 527/2002 (dep. Euler Morais) propõe que se estabeleçam percentuais mínimos de execução obrigatória das despesas. O Projeto de Lei Complementar (PLP) 87/2003 (dep. Reginaldo Germano) visa a alterar a Lei de Responsabilidade Fiscal, para que a LOA contenha projetos, designados na LDO, cujas dotações devam ser obrigatoriamente executadas. Sem maiores sutilezas, a PEC 169/2003 (dep. Jaime Martins) torna o orçamento impositivo, conforme os planos anteriormente elaborados. O PLP 218/2004 (dep. Yeda Crusius) pretende alterar a LRF para tornar o orçamento 
impositivo, salvo caso de frustração da receita, caso em que caberia à CMO decidir definitivamente se o governo fica autorizado a não gastar. A PEC 385/2005 (dep. Marcondes Gadelha) também obriga à execução das emendas parlamentares, salvo aquelas cuja anulação foi previamente aprovada pelo Congresso. Finalmente, o PLP 15/2007 (dep. Onyx Lorenzoni) tem por objetivo tornar os gastos com segurança pública obrigatórios, reduzindo-se as despesas correntes em $0,1 \%$ do PIB ao longo de dez anos.

Com início da tramitação no Senado, a PEC 2/2000 (sen. José Alencar) já propunha a execução obrigatória das emendas parlamentares. A PEC 28/2000 (sen. Pedro Simon e outros) obrigaria o Presidente a enviar ao Congresso mensagem em que constassem os créditos que não seriam totalmente gastos no exercício. Foi apensada à PEC 22/2000, que será considerada destacadamente em razão de sua importância. No ano de 2002, foi proposta a PEC 9 (sen. Marina Silva), que mudaria a organização da LOA, a qual passaria a compreender o orçamento fiscal, o orçamento social e o orçamento previdenciário. As despesas do orçamento social seriam de execução obrigatória. A PEC 24/2003 (sen. Paulo Paim) propôs a vedação do contingenciamento de recursos do orçamento da seguridade social. O Projeto de Lei do Senado Federal (PLS) 84/2006 (sen. Antônio Carlos Valadares), também sem maiores distinções e condições de flexibilidade, estabelece a execução obrigatória do orçamento, conforme a LDO. Finalmente, o PLS 134/2006 (sen. Álvaro Dias) propugna a alteração da LRF para proibir a limitação de empenho de despesas destinadas à segurança pública, criando uma hipótese de crime de responsabilidade do Presidente da República no caso de seu descumprimento.

Muitas destas propostas já foram arquivadas ou apensadas a outras, que ainda se encontram em tramitação. Em fase mais avançada, contudo, está a PEC 565/2006, que tem diversos objetivos. Muitos deles estão diretamente relacionados à qualidade da execução orçamentária: procura-se coibir os chamados projetos "guarda-chuvas", que deverão ser mais bem especificados de forma a atender um dos objetivos da programação - a diminuição de desigualdades inter-regionais. De outra parte, tal proposta também apresenta como finalidade a inclusão de novos programas no orçamento somente depois que os programas anteriores tiveram sua execução adequadamente garantida com volume suficiente de recursos. Desta forma, pretende-se 
evitar o abandono de obras. Especificamente no que toca ao chamado orçamento impositivo, porém, esta proposta vislumbra a possibilidade que obrigar o Poder Executivo a realizar o orçamento da maneira como foi aprovado pelo Poder Legislativo. O instrumento que seria utilizado para isso seria a necessidade de que o Presidente da República tivesse que solicitar ao Congresso Nacional autorização para não gastar, total ou parcialmente, os recursos de determinada dotação, justificando a medida em termos econômicos, técnicos, operacionais ou jurídicos. Até aí, tudo parece muito semelhante ao sistema norte-americano de contingenciamento de recursos, mas com algumas diferenças: o pedido governamental teria que ser feito em até 120 dias antes do encerramento da sessão legislativa, e o silêncio parlamentar implica a aprovação automática da solicitação. O descumprimento da vontade parlamentar caracterizaria crime de responsabilidade por parte do Presidente. Os prazos estabelecidos tampouco prevalecem no caso de frustração da receita ou de situações emergenciais (como guerras e calamidades públicas), quando a solicitação pode ser feita a qualquer momento. Ainda que esta PEC fosse aprovada, contudo, haveria uma dificuldade posterior: lei complementar deveria ser editada para regulamentá-la. Esta disposição parece ter caráter meramente postergatório $^{266}$.

Uma transformação deste tipo envolve uma série de aspectos. Sob um ponto de vista jurídico, trata-se de estender à limitação de empenho e movimentação financeira alguma forma de participação parlamentar que já existe com relação a outros instrumentos de flexibilidade orçamentária. É a Constituição Federal, desta forma, que prevê a necessidade de autorização parlamentar para a abertura de créditos adicionais ou sua ratificação, bem como para a transferência de recursos. A participação do Poder Legislativo na execução orçamentária já existe na ordem jurídico-orçamentária brasileira. O que se pretende com o chamado orçamento impositivo é ampliar esta atuação conjunta também à decisão governamental de não gastar, na qual se observa com nitidez a extensão dos poderes atribuídos ao Poder Executivo - poderes que, dada a própria disciplina constitucional da execução orçamentária, podem ser reduzidos, criando-se restrições para os gastos abaixo do teto que já existem em outras decisões executórias do orçamento.

\footnotetext{
${ }^{266}$ NUNES, S. P. Reforma orçamentária: riscos e oportunidades. Instituto de Estudos Sócio-Econômicos, Brasília, n. 96, abr. 2005, p. 8 .
} 
Não é possível perder de vista, todavia, que o processo orçamentário não funciona para si mesmo. A maneira como se distribui a competência decisória sobre o dinheiro público faz parte de combinações institucionais de maior abrangência. Muito se pode questionar para além da viabilidade jurídica ou do sentido constitucional da medida. O poder acachapante do Presidente da República, do qual o poder financeiro é uma das maiores expressões, tem implicações políticas de monta, e não é exagerado supor que uma mudança substancial nas relações entre os poderes na fase de execução orçamentária significaria um rearranjo institucional historicamente significativo. Que o Congresso brasileiro tivesse o mesmo grau de participação na decisão de execução do orçamento que tem o norte-americano, é algo que dependeria de condições objetivas no campo político. A viabilidade do orçamento impositivo impõe considerar algumas alterações nas relações de poder.

É possível imaginar que, como uma decisão unilateral passaria a ser negociada, o Executivo veria seu poder de barganha enfraquecido, ao passo que o Poder Legislativo se fortaleceria. A prática da liberação ou bloqueio de recursos antes de votações importantes do Congresso tenderia a ser modificada. ${ }^{267}$ A oposição também seria beneficiada, pois haveria maiores dificuldades para que o Executivo liberasse discricionariamente recursos para obras locais de acordo com o apoio manifestado pelo parlamentar. As emendas individuais poderiam ser implementadas independentemente do partido do autor, pois todos os parlamentares, atualmente, têm direito a uma quantidade fixa de recursos. Paralelamente, as vantagens que os parlamentares da situação têm em relação a parlamentares da oposição se veriam diminuídas. Um orçamento impositivo, deste modo, "não seria neutro dentro do parlamento". ${ }^{268} \mathrm{~A}$ instituição parlamentar como um todo atingiria um grau de participação no processo orçamentário, ao menos em sua potencialidade, nunca anteriormente alcançado. Este quadro permite antever dificuldades fundamentais para alterações com esta profundidade nas relações de poder entre Executivo e Legislativo, bem como entre governo e oposição: por que aqueles que se beneficiam do atual modelo de execução orçamentária se esforçariam para alterá-lo?

\footnotetext{
267 Para uma análise detalhada sobre o funcionamento do orçamento público como instrumento de barganha, cf. PEREIRA, C.; MÜLLER, B. Comportamento estratégico em coalizões presidenciais: as relações entre Executivo e Legislativo na elaboração do orçamento brasileiro. Dados, Rio de Janeiro, v. 5, n. 2, 2002.

268 LIMA, E. C. P. Algumas Observações Sobre Orçamento Impositivo no Brasil. Planejamento e Políticas Públicas - PPP, Brasília, n. 26, 2003, p. 11.
} 
Encontra-se na literatura, ainda, a dúvida a respeito do esforço da opinião pública e da pressão social para uma alteração deste naipe, ainda que se trate de um problema diacrônico no Brasil. O hermetismo da linguagem e o fato de os ganhos não serem imediatamente perceptíveis para a população, como ocorreria com a reforma tributária ou previdenciária, fazem com que a discussão sobre uma reforma orçamentária não encha a praça e fique restrita a especialistas. ${ }^{269}$ A mobilização social pela construção de maiores prerrogativas parlamentares na execução orçamentária parece difícil de antever, com certo grau de realismo. Num cenário em que pesquisas de opinião apontam o descrédito com o Congresso Nacional, cuja aprovação social é menor que a do governo ou da figura pessoal do Presidente da República, a legitimidade de uma mudança que favorecesse o Legislativo em detrimento do Executivo pode ser questionada. Há dificuldades políticas de peso, portanto, para uma reforma da execução orçamentária.

Ainda uma marca pode atingir o orçamento impositivo: a de que se trata de um daqueles problemas que só podem ser resolvidos em conjunto com outros. O sistema orçamentário brasileiro apresenta uma série de inconsistências que poderiam ser agravadas com a obrigatoriedade de execução dos montantes orçamentários. De certa forma, a ampla utilização de instrumentos de flexibilidade pelo governo tem causas mais profundas relacionadas às finanças públicas. Um orçamento composto em sua grande parte de despesas obrigatórias, que o tornam bastante rígido, acantona as possibilidades de uma política fiscal eficiente ao corte da parte discricionária dos gastos públicos, identificada predominantemente com os investimentos. São estes que oferecem possibilidades de corrigir desequilíbrios fiscais pelo corte de despesas, dadas as dificuldades de cortar gastos fixos. De outro lado, quanto ao aumento da receita, o sistema tributário brasileiro produz fortes incentivos para que o governo federal aumente sua arrecadação utilizando-se das contribuições, não repartidas entre os entes da federação. A vinculação das contribuições à seguridade social foi parcialmente contornada com a implementação da Desvinculação de Receitas da União (DRU), segundo a qual $20 \%$ das receitas vinculadas podem ser manejadas para outros fins. Os outros $80 \%$, porém, ficam referidos a um fim específico. A rigidez orçamentária, assim, gera uma dificuldade de ordem estrutural nas finanças públicas: a geração de superávits orçamentários por meio do aumento das contribuições faz com que cresça a receita

${ }^{269}$ REZENDE, F. A Reforma Orçamentária e a Eficiência Fiscal. IPEA: Brasília, 2009, p. 29 e ss. 
vinculada à seguridade social, o que abre espaço para a criação de programas que se tornam despesas obrigatórias, relacionadas à previdência social, assistência social ou saúde. O financiamento do superávit tende, desde modo, a aumentar a rigidez do orçamento. Num momento seguinte, porém, para continuar a política do superávit é necessário aumentar ainda mais as contribuições, numa situação em que se torna extremamente difícil recuar. Este efeito, batizado "efeito cremalheira", é acompanhado ainda de outro, o "efeito bumerangue": para atenuar o impacto do crescimento de despesas obrigatórias, a saída é impor restrições aos gastos na execução orçamentária, promovendo contingenciamentos e transferências para exercícios seguintes, mediante os restos a pagar. A baixa qualidade da gestão orçamentária, que na prática acaba se voltando para garantir condições de formação de superávit, e não a consecução de políticas e programas orçamentários, decorre de aspectos estruturais das finanças públicas. Parte do problema da flexibilidade, pois, se origina no excesso de rigidez do orçamento $^{270}$.

Isto não deve, em si, impedir a ampliação dos poderes parlamentares na execução orçamentária, pois com isto não se deve entender que os mecanismos para alteração do orçamento ficarão extintos. Um orçamento impositivo radicalizado a este ponto seria certamente pernicioso, e as possibilidades de ajuste fiscal devem ser mantidas. Isto já é, no mais, previsto pela LRF, que vincula o contingenciamento ao cumprimento de metas fiscais. É inegável, porém, que restrições ao contingenciamento de recursos devem levar em consideração a importância que eles adquiriram para a gestão macroeconômica do país. Neste sentido, uma reforma orçamentária deve ser amplamente compreendida. Todo seu potencial para conferir maior qualidade às finanças públicas depende não só da construção de instrumentos para assegurar o cumprimento dos programas orçamentários, favorecendo o planejamento, mas também para garantir a racionalização do orçamento no Estado brasileiro, que habitualmente recorre à vinculação de receitas, ao artifício dos restos a pagar, ao desvio de finalidade dos programas, dentre outras práticas que não serão aqui exauridas. O orçamento impositivo deve ser pensado como mais uma das modificações necessárias nas finanças públicas, que, entretanto, não são poucas e demandam uma solução articulada.

\footnotetext{
${ }^{270}$ A descrição de ambos os efeitos é amplamente descrita em REZENDE, F. A Reforma Orçamentária e a Eficiência Fiscal. IPEA: Brasília, 2009, p. 9 e ss
} 


\section{CONCLUSÃO}

A análise mais detida dos instrumentos de flexibilidade da execução orçamentária permite apontar uma espécie de indecisão normativa a respeito de suas finalidades. Se alguns deles são dotados de procedimento que garante, ao menos potencialmente, o exercício de competências parlamentares nesta etapa do ciclo orçamentário, outros não contam com esta disciplina mais rígida.

Se, no momento de executar o orçamento, o Poder Executivo se depara com insuficiência de recursos em alguma dotação destinada a determinado programa, há alguns instrumentos colocados pela ordem jurídica à sua disposição. É possível que abra créditos suplementares ou especiais, e situações excepcionais ainda lhe autorizam recorrer ao crédito extraordinário. No caso daqueles dois primeiros, deve apresentar a devida justificativa ao Poder Legislativo, que decidirá a respeito. No caso do terceiro, fica autorizado a se valer de ato próprio para cobrir a despesa imprevisível e urgente, mas, pelo procedimento próprio das medidas provisórias, cabe ao parlamento aceitá-lo ou não, ainda que em momento posterior. Há, ainda, a possibilidade de transferir, remanejar ou transpor recursos de uma dotação para outra, também por meio de lei específica, mesmo que não seja possível ver com nitidez a necessidade destas transferências, sendo possível abrir um crédito adicional. Situação ainda a ser considerada é a autorização concedida pelo Poder Legislativo, por meio de um decreto legislativo incorporado à lei de orçamento, para que o Presidente da República abra créditos suplementares dentro de determinados limites.

Aqueles instrumentos em que o Poder Legislativo autoriza o gasto previamente e de maneira específica lhe conferem um elevado grau de participação na execução orçamentária, pois é de seu consentimento que depende o Poder Executivo. Em se tratando dos créditos extraordinários ou suplementares abertos nos limites das margens de remanejamento, esta interferência é menor, pois ou não é prévia, ou não é específica. Há maior espaço de liberdade para que o Executivo tome decisões a este respeito. O Legislativo se pronunciará sobre a medida provisória que instituiu o crédito extraordinário quando muitas vezes o gasto já foi realizado, inviabilizado sua rejeição. E as decisões sobre os créditos suplementares previamente autorizados ficam submetidas 
apenas a um controle político, quando divulgados os relatórios e balanços da execução orçamentária.

De maneira mais intensa ou atenuada, o Parlamento é chamado a participar da decisão do governo quando é necessário superar a autorização inicial ou, ainda, criar autorização nova. Tais institutos se destinam, de forma clara, a assegurar o cumprimento da vontade parlamentar, manifestada no orçamento aprovado. Objetivam a um maior controle sobre o cumprimento das políticas definidas em conjunto entre Executivo e Legislativo. É para o cumprimento destas políticas que se destina a etapa de execução, que, por seu caráter administrativo, não poderia inovar a lei.

Quando se trata da decisão de não gastar, porém, o problema é mais delicado. E é mais delicado porque é neste momento em que o silêncio da disciplina constitucional (que fala muito de créditos adicionais e transferências, mas nada de bloqueio de recursos) estimula o surgimento de posições que consagram a fase de execução como uma prerrogativa eminentemente governamental. Sem que haja suficiente fundamentação constitucional para tanto, a idéia de que a lei de orçamento tem caráter de autorização surge com grande força para afastar as possibilidades de participação parlamentar. Nisto há uma incoerência: o Poder Legislativo não fica inerte durante a fase de execução orçamentária. Em diversos momentos é chamado a dela participar, como ficou demonstrado no processo legislativo de diversos instrumentos de flexibilização do orçamento. A execução orçamentária como uma prerrogativa governamental apenas tem algum sentido se se entende que cabe, efetivamente, ao Poder Executivo tomar as decisões administrativas para executar o orçamento aprovado. A natureza administrativa de sua atividade orçamentária não lhe permite, porém, modificar os objetivos orçamentários.

Isto porque o orçamento é a expressão de uma política veiculada por lei. Trata-se de uma característica historicamente recente incorporada às funções do orçamento público, mas que lhe confere um traço fundamental: a de que se destina a atingir objetivos. Para estes objetivos é que existem os créditos orçamentários. A necessidade de que estes créditos sejam aprovados pelo Poder Legislativo não pode ter por sentido apenas que o parlamento, e o povo por ele representado, simplesmente tomem conhecimento das políticas adotadas, mas também que delas participem, decidindo-as. Ato conjunto entre Executivo e Legislativo, a previsão de que o orçamento se trata 
ainda de lei o situa no campo em que é o Poder Legislativo o órgão dotado de primazia constitucional. Alterar o orçamento significa, deste modo, alterar uma lei que define políticas, e isto não pode ser feito sem a participação parlamentar.

Não deve subsistir, assim, a prática de conferir ao contingenciamento de recursos a característica de um instrumento autônomo de flexibilidade, que serve para modificar substancialmente os programas orçamentários, não os cumprindo. A disciplina legal do tema, conferida atualmente pela Lei de Responsabilidade Fiscal, autoriza a limitação de empenho e movimentação financeira numa hipótese específica, destinada a permitir o ajuste fiscal no caso de frustração da receita. Seu uso indiscriminado tem se firmado mais como um elemento das relações de poder existentes entre Executivo e Legislativo do que como uma ocorrência fundamentada na lei e na sistemática constitucional das atribuições parlamentares no orçamento público.

Tem-se falado sobre a necessidade de um orçamento impositivo para resolver a situação. A tendência é que tais propostas reconheçam a necessidade de flexibilizar o orçamento, mas a condicionem à manifestação parlamentar. Como esta autorização já deve existir no caso de diversos outros instrumentos, de acordo com a Constituição Federal, instituir um orçamento impositivo, na prática, atingiria objetivamente os contingenciamentos de recursos. Não se trata, assim, de um orçamento absolutamente impositivo, mas de algo que pode ser alterado com o consentimento parlamentar, também no que toca ao descumprimento dos tetos das dotações. Conferiria maior efetividade ao princípio orçamentário da especialidade quantitativa, desdobramento da legalidade.

A relativização de uma rígida separação de fases do ciclo orçamentário foi uma proposta deste trabalho. A ideia de equilíbrio conferida pela atribuição de duas fases para o Executivo e duas para o Legislativo não cumpre bem seu objetivo, justamente porque a execução orçamentária comportaria uma série de medidas que, atribuídas exclusivamente ao governo, poderiam anular a função orçamentária do parlamento. E encontram-se na ordem constitucional vigente diversos elementos que já prevêem a participação parlamentar na execução, de forma ora mais, ora menos intensa. $O$ orçamento impositivo, portanto, não seria uma inovação constitucional, mas uma efetivação concreta e específica de seus contornos mais fundamentais, levando à valorização do planejamento e da decisão político-legislativa no campo orçamentário. 
Há sérias dificuldades para isso, no entanto, que ultrapassam apenas o elemento constitucional. Ou melhor, que ultrapassam a consideração constitucional formal e tocam nas efetivas relações de poder, tanto no campo político quanto na condução das finanças públicas. O contingenciamento de recursos adquiriu enorme importância para as negociações políticas entre governo e parlamento, e também para a gestão macroeconômica, ao se tornar um dos instrumentos por excelência do ajuste fiscal. Corrigir uma distorção consistente no desequilíbrio favorável ao Executivo, em detrimento da posição do Legislativo, envolve, portanto, uma série de outras medidas necessárias a uma maior racionalidade do processo orçamentário. Maior participação do Parlamento na decisão de não gastar seria um avanço relevante, mas, neste caso, cumprir a Constituição formal parece esbarrar na Constituição real, aquela que efetivamente rege as relações entre governo, parlamento e sociedade no país. 


\section{BIBLIOGRAFIA}

ADAMS, H. C. The Science of Finance. New York: Henry Holt \& Co., 1898.

ALMEIDA, C. O. F. O Planejamento Financeiro Responsável: boa governança e desenvolvimento no estado contemporâneo. In: CONTI, J. M.; SCAFF, F.F. Orçamentos Públicos e Direito Financeiro. São Paulo: RT, 2011.

AMARAL, Diogo Freitas do. Curso de Direito Administrativo. $2^{\mathrm{a}}$ ed. Coimbra: Almedina, 2004. v. 2.

ARGENTINA. Ministerio de Economía y Finanzas Públicas. El Sistema Presupuestario en la Administración Nacional de la República Argentina. Buenos Aires: Gobierno Federal, 2008.

AUTEN, Gerald; BOZEMAN, Barry; CLINE, Robert. A Sequential Model of Congressional Appropriations. American Journal of Political Science, v. 28, n. 3, ago. 1984, p. 503-523.

AXELROD, D. Budgeting for Modern Government. New York: St. Martin's Press, 1988.

BALEEIRO, Aliomar. Uma Introdução à Ciência das Finanças. 15ª ed. Rio de Janeiro: Forense, 1998.

BASTOS, Celso. Curso de direito financeiro e tributário. $3^{\text {a }}$ ed. São Paulo: Saraiva, 1995.

BAYBROOKE, D.; LINDBLOM, C. A Strategy of Decisions: Policy Evaluation as a Social Process. New York: Free Press of Glencoe, 1963.

BENETON, Marco Antônio Halem. O processo legislativo financeiro, 2007. Dissertação (Mestrado), São Paulo, Departamento de Direito Econômico- Financeiro da Faculdade de Direito da Universidade de São Paulo. 
BERRY, W. The Confusing Case of Budgetary Incrementalism: too many meanings for a single concept. The Journal of Politics, v. 52, n. 1, fev. 1990, p. 167-196.

BEZERRA, Marcos Otávio. Em Nome das Bases: política, favor e dependência pessoal. Rio de Janeiro: Relume Dumará, 1999.

BILFINGER, C. Der Streit um das Panzerschiff A und die Reichsverfassung. Archiv des öffentlichen Rechts (AöR), Tübingen, v. 55, 1929.

BLANKART, Charles B. Öffentliche Finanzen in der Demokratie: eine Einführung in die Finanzwissenschaft. $7^{\text {a }}$ ed. München: Vahlen, 2008.

BOBBIO, Norberto. Estado, Governo e Sociedade: para uma teoria geral da política. $11^{\mathrm{a}}$ ed. São Paulo: Paz e Terra, 2004.

BÖCKENFÖRDE, Ernst-Wolfgang. Die Organisationsgewalt im Bereich der Regierung: eine Untersuchung zum Staatsrecht der Bundesrepublik Deutschland. Berlin: Duncker \& Humblot, 1964.

BOITEAU, P. Budget Général de l'Etat. In: SAYS, L. Dictionnaire des Finances, Paris: Berger-Levrault, 1889. v. 1.

BONAVIDES, P. Ciência Política. 10ª ed. São Paulo: Malheiros, 2000.

BOUVIER, M.; ESCLASSAN, M.-C.; LASSALE, J.-P. Finances Publiques. $7^{\mathrm{a}}$ ed. Paris: LGDJ, 2004.

BOZEMAN, B.; STRAUSSMAN, J. Shrinking Budgets and the Shrinkage of Budget Theory. Public Administration Review, v. 42, n. 6, 1982, p. 509-515.

BURKHEAD, Jesse. Government Budgeting. New York: Wiley, 1956. 
BRASIL. Ministério do Planejamento. Manual Técnico Orçamentário 2011. Brasília: Secretaria de Orçamento Federal, 2011.

BUEHLER, Alfred G. Public Finance. $3^{\mathrm{a}}$ ed. York: Mc. Graw-Hill Book Company, 1948.

BURKHEAD, Jesse. Government Budgeting. New York: John Wiley \&Sons, 1956.

CAIDEN, N. Paradox, Ambiguity, and Enigma: the Strange Case of the Executive Budget and the United States Constitution. In: RUBIN, I. (ed.). Public Budgeting: policy, process and politics. New York: ASPA Classis, 2008.

CARDOSO Jr, José Celso. Planejamento Governamental e Gestão Pública no Brasil: elementos para ressignificar o debate e qualificar o Estado. Brasília: IPEA, 2011.

CAREY, J.; SHUGART, M. Executive Decree Authority. New York: Cambridge University Press, 1998.

CARREIRA, Liberato de Castro. História Financeira e Orçamentária do Império do Brazil desde a sua Fundação. Rio de Janeiro: Imprensa Nacional, 1880.

CAVALCANTI, Amaro. Elementos de Finanças: estudo teórico-prático. Rio de Janeiro: Imprensa Nacional, 1896.

CHATEAUBRIAND, F-R. De la Monarchie selon la Charte. Paris: Normant, 1826.

CIRNE LIMA, Ruy. Princípios de Direito Administrativo. $7^{\mathrm{a}}$ ed. São Paulo: Malheiros, 2007.

CLEVELAND, F. A.; BUCK, A. E. The Budget and Responsible Government. New York: Macmillan, 1888.

CONTI, José Maurício. A Autonomia Financeira do Poder Judiciário. São Paulo: MP Editora, 2006. 
CONTI, José Maurício. Iniciativa Legislativa em Matéria Financeira. In: CONTI, J. M.; SCAFF, F.F. (coords.). Orçamentos Públicos e Direito Financeiro. São Paulo: RT, 2011. (coord.). Orçamentos Públicos - A Lei 4.320/1964 comentada. São Paulo: RT, 2009.

COSCIANI, Cesare. Scienza delle Finanze. 8ª ed. Torino: UTET, 1977.

COUTO, Cláudio Gonçalves. O Avesso do Avesso: conjuntura e estrutura na recente agenda política brasileira. Perspectiva, São Paulo, v.15, n.4, out./dez. 2001, p. 32-44.

COWART, A.; HANSEN, T.; BOFOSS, K. Budgetary Strategies and Sucess at Multiple Decision Levels in the Norwegian Urban Setting. American Political Science Review, v. 69, 1975, p. 543-558.

DAHL, R. A.; LINDBLOM, C. Politics, Economics and Welfare. New York: Harper and Row, 1953.

DAVIS, Otto A.; DEMPSTER, M. A. H., WILDAVSKY, A. A Theory of the Budgetary Process. The American Political Science Review, v. 60, n. 3, set. 1966, p. 529-547.

DIAMOND, Jack. From Program to Performance Budgeting: the Challenge for Emerging Market Economies. Washington: International Monetary Fund (Working Paper), jun. 2003. 28 p.

DI FABIO, Udo. Gewaltenteilung. In: ISENSEE, J.; KIRCHHOF, P. (ed.). Handbuch des Staatsrechts. $3^{\mathrm{a}}$ ed. Heidelberg: C. F. Müller Verlag, 2004.

DUARTE, Manuel. Questões financeiras. Coimbra: ed. Francisco Amado, 1893.

DUVERGER, Maurice. Finances Publiques. Paris: Presses Universitaires de France, 1975. 
DUVERGER, Maurice. Institutions Politiques et Droit Constitutionnel. $11^{\mathrm{a}}$ ed. Paris: Presses Universitaires de France, 1970.

FALCÓN Y TELLA, R. Introducción al Derecho Financiero y Tributario de las Comunidades Europeas. Madrid: Civitas, 1988.

FENNO, R. The Power of the Purse: Appropriations Politics in Congress. Boston: Little Brown, 1966.

FERREIRA FILHO, M. G . Comentários à Constituição Brasileira. $5^{\text {a }}$ ed. São Paulo: Saraiva, 1984 Curso de Direito Constitucional. 27ª ed. São Paulo: Saraiva, 2001. . Do processo legislativo 5a ${ }^{\text {a }}$ ed. São Paulo: Saraiva, 2002.

FITZPATRICK, E. A. Budget Making in a Democracy. New York: Macmillan, 1918.

FÖLSCHER, Alta. Budget Methods and Practices. In SHAH, Anwar (coord.). Budgeting and Budgetary Institutions. Washington: The World Bank, 2007.

FONROUGE, Carlos M. Giuliani. Derecho Financiero. $2^{\mathrm{a}}$ ed. Buenos Aires: Depalma, 1970. v. 1.

FRIAUF, K. Der Staatshaushaltsplan im Spannungsfeld zwischen Parlament und Regierung. Bad Homburg - Berlin - Zürich: Gehlen, 1968. v. 1.

GAUDEMET, P.-M.; MOLINIER, J. Finances Publiques. $7^{\mathrm{a}}$ ed. Paris: Montchrestien, 1996. Tomo 1.

GIACOMONI, James. Orçamento Público. 13 ${ }^{\mathrm{a}}$ ed. São Paulo: Atlas, 2005. 
GIAMBIAGI, Fábio; ALÉM, Ana Cláudia. Finanças Públicas. Rio de Janeiro: Campus, 2007.

GIANNINI, A. D. Elementi di Diritto Finanziario. Milano: Giuffrè, 1945.

GNEIST, Rudolf von. Budget und Gesetz. Berlin: Springer, 1867.

GOODNOW, F. Politics and Administration: a Study in Government. New Brunswick, NJ: Transaction Publishers, 2003.

GÖTZ, V. Recht der Wirtschaftssubventionen. München: Beck, 1966.

GRIZIOTTI, Benvenuto. Princípios de Ciencia de las Finanzas. $6^{\mathrm{a}}$ ed. Buenos Aires: Roque Depalma Editor, 1959.

HÄNEL, A. Studien zum Deutschen Staatsrechte. Leipzig: Hässel, 1873. v. 2.

HECKEL, J. Die Legitimation des Grundgesetzes durch das deutsche Volk. In: ISENSEE, J.; KIRCHHOF, P. (ed.). Handbuch des Staatsrechts. $2^{\mathrm{a}}$ ed. Heidelberg: C. F. Müller Verlag, 1999. v. 2.

HEINIG, K. Das Budget. Tübingen: J. C. B. Mohr (Paul Siebeck), 1949. v. 1.

HETTLAGE, K. Die Finanzverfassung im Rahmen der Staatsverfassung. Veröffentlichung der Vereinigung der Deutschen Staatsrechtslehrer, Berlin, n. 14, 1956.

HIRSCH, J.; SCHRÖDER, A.; ELLWEIN, T.; GÖRLITZ, A. Haushaltsplanung und Haushaltskontrolle in der Bundesrepublik Deutschland. Stuttgart-Berlin-Köln-Mainz: Kohlhammer, 1968.

HOFFMAN, Reinhard. Haushaltsvollzug und Parlament. Tübingen: J. C. B. Mohr (Paul Siebeck), 1972.

HÖPKER-ASCHOFF, Hermann. Das Finanzwesen der Bundesrepublik: Bemerkungen zu dem Buch von G. Wacke. Finanzarchiv, Tübingen, v. 12, 1950/51, n.4, p. 725-29. 
HOPPE, W. Planung. In: ISENSEE, J.; KIRCHHOF, P. (ed.). Handbuch des Staatsrechts. $3^{\text {a }}$ ed. Heidelberg: C. F. Müller Verlag, 2004.

INTERNATIONAL MONETARY FUND. Code of Good Practices on Fiscal Transparency. Washington: IMF, 2007.

ISENSEE, J.; KIRCHHOF, P. (ed.). Handbuch des Staatsrechts. $3^{\text {a }}$ ed. Heidelberg: C. F. Müller Verlag, 2004.

JARACH, Dino. Finanzas Publicas y Derecho Tributario. Buenos Aires: ed. Cangallo, 1985.

JELLINEK, G. Gesetz und Verordnung. Freiburg i. B.: Mohr, 1887.

JESCH, D. Gesetz und Verwaltung. 2a ed. Tübingen: Mohr Siebeck, 1968.

JÈZE, Gaston. Cours de Science des Finances et de Législation Financière Française. $6^{\mathrm{a}}$ ed. Paris: Marcel Giard, 1922.

KELSEN, H. Teoria Geral do Direito e do Estado. Tradução de Luís Carlos Borges. São Paulo: Martins Fontes, 2005.

KEWENIG, W. Staatsrechtliche Probleme parlamentarischer Mitregierung am Beispiel der Arbeit der Bundestagsausschüsse. Bad Homburg v.d.H.: Gehlen, 1970.

KIEWIET, Roderick; McCUBBINS, Mathew. Appropriations Decisions as a Bilateral Bargaining Game between President and Congress. Legislative Studies Quarterly, v. 10, n. 2, mai. 1985 , p. 181-201.

Congressional Appropriations and the Electoral Connection. The Journal of Politics, v. 47, n. 1, fev. 1985, p. 59-82. 
KIEWIET, Roderick; McCUBBINS, Mathew. Presidential Influence on Congressional Appropriations Decisions. American Journal of Political Science, v. 32, n. 3, ago. 1988, p. 713-36.

KISKER, Gunter. Staatshaushalt. In: ISENSEE; KIRCHHOF (ed.). Handbuch des Staatsrechts. 2a ed. Heidelberg: C. F. Müller Verlag, 1999.

KRÜGER-SPITTA, Wolfgang; BRONK, Horst. Einführung in das Haushaltsrecht und die Haushaltspolitik. Darmstadt: Wissenschaftliche Buchgesellschaft, 1973.

LABAND, Paul. Das Budgetrecht: Nach den Bestimmungen der Preussischen Verfassungs-Urkunde unter Berücksichtigung der Verfassung des Norddeutschen Bundes. Berlin: Verlag von J. Guttentag, 1871.

LASSAllE, F. Que Es Una Constitución?. Tradução de W. Roces. Buenos Aires: Ediciones Siglo Veinte, 1946.

LAUFENBURGER, Henry. Traité d'Économie et de Législation Financières. $3^{\mathrm{a}}$ ed. Paris: Librairie du Recueil Sirey, 1948.

LEE, Robert D. Public Budgeting Systems. $8^{\mathrm{a}}$ ed. Gaithersburg: Jones and Bartlett, 1998.

LELOUP, L. The Myth of Incrementalism: Analytical Choices in Budgetary Theory.Polity, v. 10, n. 4, 1978, p. 488-509.

LIENERT, I. Who Controls the Budget: the Legislature or the Executive?. Washington: International Monetary Fund (Working Paper), 2005. 26 p.

LIMA, E. C. P. Algumas Observações Sobre Orçamento Impositivo no Brasil. Planejamento e Políticas Públicas - PPP, Brasília, n. 26, 2003.

LINDBLOM, C. The Science of Muddling Through. Public Administration Review, v. 19, n. 2, 1959, p. 79-88. 
LUCARELLI, A. Teorie del Presidenzialismo: fondamento e modelli. Verona: Grafiche Fiorini, 2000.

MACHADO Jr., José Teixeira; REIS, Heraldo da Costa. A Lei 4.320 comentada e a lei de responsabilidade fiscal $31^{\mathrm{a}}$ ed. Rio de Janeiro: IBAM, 2002/2003.

MANDELARTZ, H. Das Zusammenwirken von Parlament und Regierung beim Haushaltsvollzug: ein Beitrag zur parlamentarischen Regierungssystem der Bundesrepublik Deutschland. Frankfurt a.M.: Peter D. Lang, 1980.

MAYER, Otto. Kleine Schriften zum Öffentlichen Recht. Berlim: Duncker \& Humblot, 1981. v. I.

MELlO, Celso Antônio Bandeira. Curso de Direito Administrativo. 26 a ed. São Paulo: Malheiros, 2009.

MORAES, A. Presidencialismo. São Paulo: Atlas, 2004.

MUßGNUG, Reinhard. Der Haushaltsplan als Gesetz. In: FORSCHUNGSGESELLSCHAFT FÜR STAATS- UND KOMMUNAL WIRTSCHAFT. Studien der Forschungsgesellschaft für Staats- und Kommunalwirtschaft e.V. $1^{\text {a }}$ ed. Frankfurt a.M.: Schwartz, 1976. v. 6

NEUMARK, Fritz. Der Reichshaushaltplan: ein Beitrag zur Lehre vom öffentlichen Haushalt. Jena: Verlag von Gustav Fischer, 1929.

Theorie und Praxis des Budgetgestaltung. In: GERLOFF, Wilhelm; NEUMARK, Fritz. Handbuch der Finanzwissenschaft. $2^{\mathrm{a}}$ ed. Tübingen: J. C. B. Mohr, 1952. v. 1.

NISKANEN, W. Bureaucracy and Representative Government. Chicago: Aldine Atherton, 1971. 
NUNES, S. P. Reforma orçamentária: riscos e oportunidades. Instituto de Estudos Sócio-Econômicos, Brasília, n. 96, abr. 2005.

OLIVEIRA, Régis Fernandes de. Curso de Direito Financeiro, São Paulo: Revista dos Tribunais, 2006.

A Lei 4.320, de 17.03.1964 (Lei Geral do Orçamento). Revista Tributária e de Finanças Públicas, São Paulo, ano 12, Nov.-Dez. 2004, p. 146-154.

Receitas Não Tributárias: taxas e preços públicos. $2^{\mathrm{a}}$ ed. São Paulo: Malheiros, 2003.

PARSONS, Talcott. On the Concept of Influence. The Public Opinion Quarterly, v. 27, n. 1, 1963, p. 37-62.

PEREIRA, C.; MÜLLER, B. Comportamento estratégico em coalizões presidenciais: as relações entre Executivo e Legislativo na elaboração do orçamento brasileiro. Dados, Rio de Janeiro, v. 5, n. 2, 2002.

PITSVADA, B. T. The Executive Budget: an idea whose time has passed. In RUBIN, I. (ed.). Public Budgeting: policy, process and politics. New York: ASPA Classis, 2008.

PONTES DE MIRANDA. Comentários à Constituição da República dos Estados Unidos do Brasil, Rio de Janeiro: ed. Guanabara, 1936. Tomo 1.

REZENDE, F. A Reforma Orçamentária e a Eficiência Fiscal. IPEA: Brasília, 2009.

RIBEIRO, José Joaquim Teixeira. Lições de Finanças Públicas. $5^{\mathrm{a}}$ ed. Coimbra: Coimbra Editora, 1997.

RODRÍGUEZ BEREIJO, A. Introducción al Estudio del Derecho Financiero. Madrid: IEF, 1976. 
ROURE, Agenor. Formação do Direito Orçamentário Brasileiro. Rio de Janeiro: Jornal do Commercio, 1916.

RUBIN, I. (ed.). Public Budgeting: policy, process and politics. New York: ASPA Classis, 2008.

. The Authorization Process: Implications for Budget Theory. In: (ed.). New Directions in Budget Theory, Albany: ed. I. S. Rubin, 1988.

- The Politics of Public Budgeting: getting and spending, borrowing and balancing. $6^{\mathrm{a}}$ ed. Washington, D.C.: CQ Press, 2010.

RUBINSTEIN, F. Notas Sobre a Transparência Fiscal no Direito Financeiro. CONTI, J. M.; SCAFF, F.F. Orçamentos Públicos e Direito Financeiro. São Paulo: RT, 2011

RÜRUP, B. Die Programmfunktion des Bundeshaushaltsplanes. Berlin: Duncker \& Humblot, 1971.

SANCHES, Osvaldo M. Processo orçamentário federal: problemas, causas e indicativos de solução. Revista de Administração Pública, Rio de Janeiro, v. 29, n. 3, jul./set. 1995.

SANTA HELENA, E.; GREGGIANIN, E.; PEREIRA FILHO, L.; SANTOS, M.; BATISTA Jr., S.; GONTIJO, V. Orçamento Impositivo e Despesas Obrigatórias Continuadas: introdução do orçamento impositivo no ordenamento brasileiro e crescimento das despesas obrigatórias continuadas. Brasília: Câmara dos Deputados, 2010 .

SCHICK, A. Congress and Money. Washington D.C.: The Urban Institute, 1980.

The Battle of the Budget. Proceedings of the Academics of Political Science, v. 32, n.1, 1975, p. 51-70. 
SCHICK, A. The Federal Budget: politics, policy, process. $3^{\mathrm{a}}$ ed. Washington D.C.: Brookings Institution Press, 2007.

SENF, P. Budget. In: Handwörterbuch der Sozialwissenschaften. Stuttgart: Fischer, 1959. v. 2, p. 427-437.

SHAH, Anwar (coord.). Budgeting and Budgetary Institutions. Washington: The World Bank, 2007.

SHEPARD, Walter James. The German Doctrine of the Budget. The American Political Science Review, v. 4, n. 1, fev. 1910, p. 52-62.

SILVA, José Afonso da. Orçamento-Programa no Brasil. São Paulo: Revista dos Tribunais, 1973.

. Curso de Direito Constitucional Positivo. 30ª ed. São Paulo: Malheiros, 2008.

Curso de Direito Constitucional Positivo. 34a ed. São Paulo: Malheiros, 2012.

STEIN, L. Lehrbuch der Finanzwissenschaft. $5^{\mathrm{a}}$ ed. Leipzig: F. A. Brockhaus, 1885. v. I.

SUNDELSON, J. Wilner. Budgetary Principles. Political Science Quarterly, v. 50, n. 2 , jun. 1935, p. 236-263.

TORRES, Ricardo Lobo. A Ideia de Liberdade no Estado Patrimonial e no Estado Fiscal. Rio de Janeiro: Renovar, 1991.

.Curso de Direito Financeiro e Tributário. $15^{\mathrm{a}}$ ed., Rio de Janeiro: ed. Renovar, 2008.

Tratado de Direito Constitucional, Financeiro e Tributário: o Orçamento na Constituição. $2^{\mathrm{a}}$ ed. Rio de Janeiro: Renovar, 2000. v. 5. 
TROTABAS, L.; COTTERET, J. Droit Budgétaire et Comptabilité Publique. $5^{\mathrm{a}}$ ed. Paris: Dalloz, 1995.

VEIGA Filho, João Pedro da. Manual de Sciencia das Finanças. $2^{\mathrm{a}}$ ed. São Paulo, Espíndola e Comp., 1906.

VIALON, F. Haushaltsrecht. 2a ed. Berlin und Frankfurt a. M.: Franz Vahlen, 1959.

VIDIGAL, Geraldo. Fundamentos do Direito Financeiro. São Paulo: Revista dos Tribunais, 1973.

VILLEGAS, Hector. Curso de Finanzas, Derecho Financiero y Tributario. $9^{\mathrm{a}}$ ed. Buenos Aires: Astrea, 2007.

VOGEL, Klaus. Der Finanz- und Steuerstaat. In: ISENSEE, J.; KIRCHHOF, P. (ed.). Handbuch des Staatsrechts. $3^{\text {a }}$ ed. Heidelberg: C. F. Müller Verlag, 2004.

VON HAGEN, J. Budgeting Institutions for Better Fiscal Performance. In: SHAH. A. (ed.) Budgeting and Budgetary Institutions. Washington: The World Bank, 2007.

WACKE, Gerhard. Das Finanzwesen der Bundesrepublik: die Einwirkungen der Finanzfunktion auf Gesetzgebung, Verwaltung und Rechtssprechung im Bonner Grundgesetz. Tübingen: J. C. B. Mohr, 1950.

WALDO, D. The Administrative State. New York: Ronald Press, 1948.

WALLACE, Robert Ash. Congressional Control of the Budget. Midwest Journal of Political Science, v. 3, n. 2, mai. 1959, p. 151-167.

WEBER, Max. Economia e Sociedade. Tradução de Régis Barbosa e Karen Elsabe Barbosa. $4^{\text {a }}$ ed. São Paulo: UnB, 2004. v. 1. 
WILDAVSKY, Aaron. Planning-Programing-Budgeting: Rescuing Policy Analysis from PPBS. Public Administration Review, Washington,D.C, v. 29, n. 2, 1969, p. 169202.

The Politics of the Budgetary Process. Boston: Little Brown, 1964.

WILDAVSKY, Aaron; CAIDEN, Naomi. The New Politics of the Budgetary Process. $5^{\mathrm{a}}$ ed. Pearson Longman, 2004.

WILlOUGHBY, W. F. The National Budget System. Baltimore: Johns Hopkins Press, 1927.

The Problem of a National Budget. New York: D. Appleton and Co. 1918.

WILSON, Woodrow. Congressional Government: a Study in American Politics. Boston: Houghton Mifflin, 1895.

WLEZIEN, Christopher. The Political Economy of Supplemental Appropriations. Legislative Studies Quarterly, v. 18, n. 1, fev. 1993, p. 51-76.

. The Politics of Impoundments. Political Research Quarterly, v. 47, n. 1, mar. 1994, p. 59-84.

ZIMMERMANN, Horst; HENKE, Klaus-Dirk; BROER, Michael. Finanzwissenschaft. $10^{\mathrm{a}}$ ed. München: Vahlen, 2009. 
